\title{
The Republic of the Philippines Coalbed Methane Assessment: Based on Seventeen High Pressure Methane Adsorption Isotherms
}

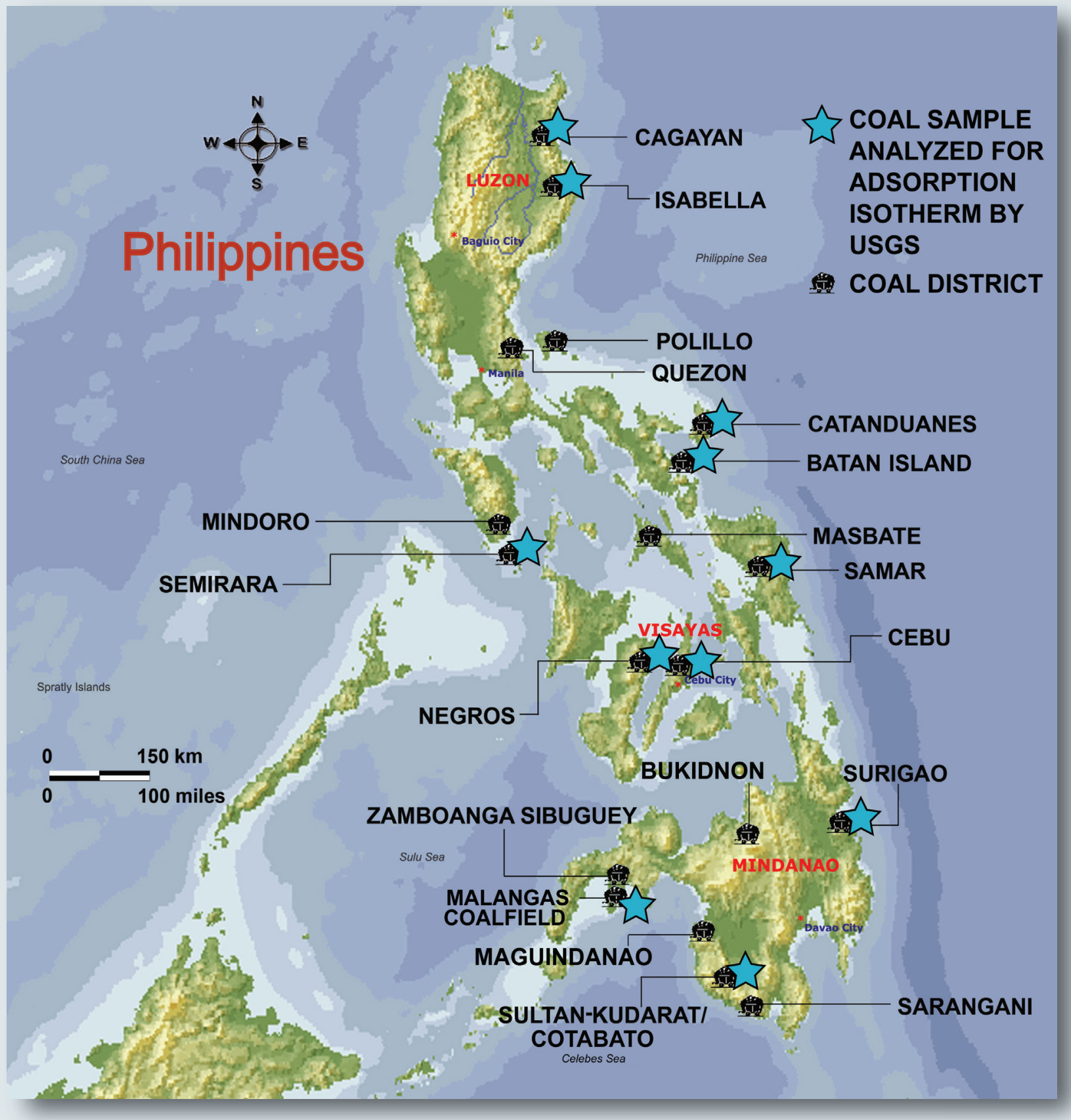

Open-File Report 2006-1063

U.S. Department of the Interior U.S. Geological Survey 


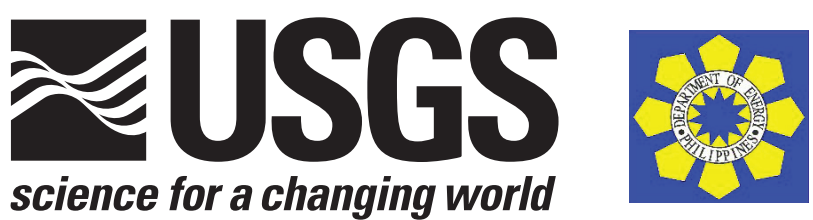

\section{The Republic of the Philippines Coalbed Methane Assessment: Based on Seventeen High Pressure Methane Adsorption Isotherms}

By Romeo M. Flores' ${ }^{1}$, Gary D. Stricker ${ }^{1}$, Ramon F. Papasin², Ronaldo R. Pendon², Rogelio A. del Rosario르, Ruel T. Malapitan², Michael S. Pastor ${ }^{2}$, Elmer A. Altomea ${ }^{2}$, Federico Cuaresma ${ }^{2}$, Armando S. Malapitan², Benjamin R. Mortos ${ }^{2}$, and Elizabeth N. Tilos ${ }^{2}$

${ }^{1}$ U.S. Geological Survey, Denver Colorado

${ }^{2}$ Philippine Department of Energy, Metro Manila, Philippines

Prepared in cooperation with the

Republic of the Philippines

Department of Energy

Energy Resources Develpment Board

Geothermal and Coal Resources Development Division

Ft. Bonifacio, Taguig 1201

Metro Manila, Philippines

Open File Report 2006-1063 


\section{U.S. Department of the Interior \\ Gale A. Norton, Secretary \\ U.S. Geological Survey \\ P. Patrick Leahy, Acting Director}

\section{U.S. Geological Survey, Reston, Virginia: 2006}

Posted online March 2006

Version 1.0

This publication is only available online at

http://www.usgs.gov/of/2006/1063

For more information on the USGS--the Federal source for science about the Earth, its natural and living resources, natural hazards, and the environment:

World Wide Web: http://www.usgs.gov

Telephone: 1-888-ASK-USGS

Any use of trade, product, or firm names is for descriptive purposes only and does not imply endorsement by the U.S. Government.

Although this report is in the public domain, permission must be secured from the individual copyright owners to reproduce any copyrighted materials contained within this report.

Suggested citation:

Flores, R.M., Stricker, G.D., Papasin, R.F., Pendon, R.R., del Rosario, R.A., Malapitan, R.T., Pastor, M.S., Altomea, E.A., Cuaresma, F., Malapitan, A.S., Mortos, B.R., and Tilos, E.N., 2006. The Republic of the Philippines coalbed methane assessment: based on seventeen high pressure methane adsorption isotherms: U.S. Geological Survey Open-File Report 2006-1063. 


\section{Contents}

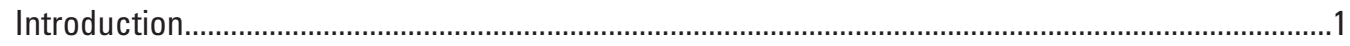

Coal Geology of Studied Philippine Coal Districts.........................................................................

Batan Island Coal District........................................................................................................

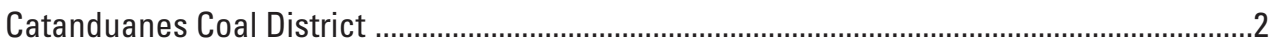

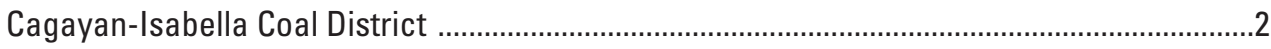

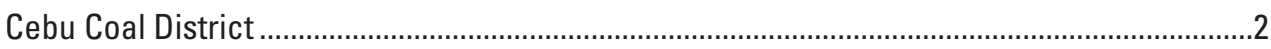

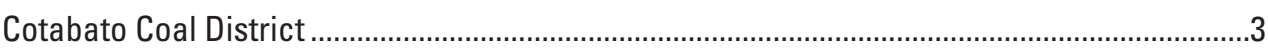

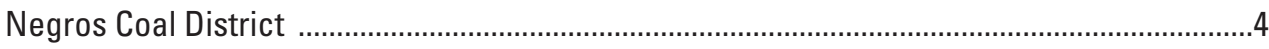

Samar (Excluding Leyte) Coal District ...............................................................................

Semirara (Excluding Mindoro) Coal District.............................................................................4

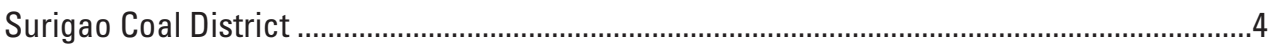

Zamboanga Sibuguey Coal District ......................................................................................

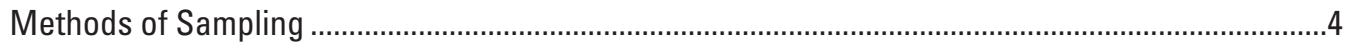

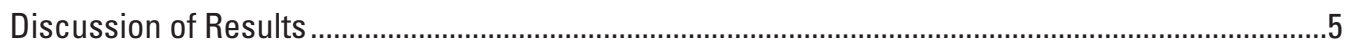

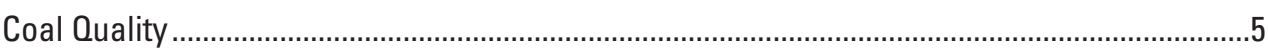

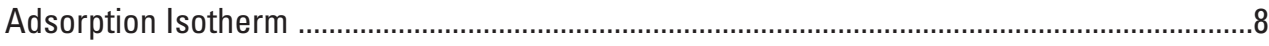

Potential Coalbed Methane Resources .........................................................................................12

Estimates from Studied Coal Districts ...................................................................................12

Estimates From Other Coal Districts ................................................................................ 12

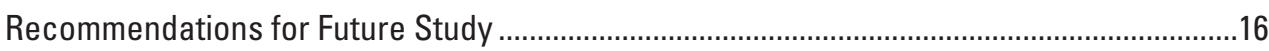

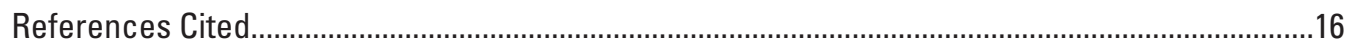

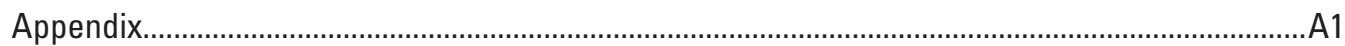

\section{Figures}

1. Coal districts of the Philippines containing lignite to semi-anthracite coal in strata ranging from Eocene to Pleistocene in age ...........................................................................2

2. Locations of coal samples from various Philippine coal districts that were analyzed by the U.S. Geological Survey..............................................................................................

3. Photograph of a dipping coal-bed outcrop in Catanduanes coal district..........................5

4. Photograph of an inclined shaft of an active underground mine in the

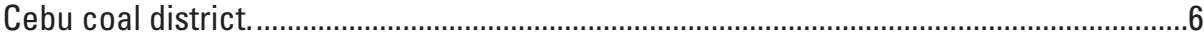

5. Photograph showing trenching at an outcrop in Catanduanes coal district for collecting coal samples .....................................................................................................

7. Photograph of drilling rig used by Semirara Mining Corporation to core coal in the Panian coalfield in the Semirara coal district.......................................................................

6. Photograph illustrating the preparation of a coal sample, immediately following collection, for shipment to laboratory ................................................................................

8. Coal core recovery from the Panian coalfield in the Semirara coal district .....................8

9. Plot of adsorbed methane versus apparent rank of Philippine coal samples.................13

10. Plot of adsorption isotherms versus equilibrium pressure of coal samples in the Semirara coal district and in the Powder River Basin, Wyoming, USA 
11. The potential minimum coalbed methane in-place resources estimated for Philippines coal districts based on ideal gas storage capacity

\section{Tables}

1. Summary of apparent rank and Langmuir parameters of Philippine coal samples.....

2. Coal chemistry for samples utilized in construction of the Philippine isotherm

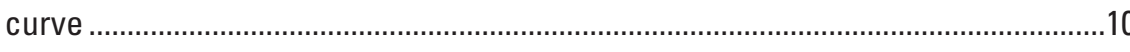

3. Coal chemistry for samples utilized in construction of the Philippine isotherm curve 


\title{
The Republic of the Philippines Coalbed Methane Assessment: Based on Seventeen High Pressure Methane Adsorption Isotherms
}

\author{
By Romeo M. Flores ${ }^{1}$, Gary D. Stricker ${ }^{1}$, Ramon F. Papasin², Ronaldo R. Pendon², Rogelio A. del Rosario², \\ Ruel T. Malapitan², Michael S. Pastor², Elmer A. Altomea², Federico Cuaresma², Armando S. Malapitan², \\ Benjamin R. Mortos², and Elizabeth N. Tilos²
}

\section{Introduction}

The Republic of the Philippines has some 19 coal districts that contain coal deposits ranging from Eocene to Pleistocene in age. These coal districts include: (1) Catanduanes (Eocene); (2) Cebu, Zamboanga Sibuguey, Bukidnon, Maguindanao, Sarangani, and Surigao (Oligocene to Miocene); (3) Batan Island, Masbate, Semirara (including Mindoro), and Quezon-Polilio (lower-upper Miocene); (4) Davao, Negros, and Sorsogon (middle-upper Miocene); (5) Cotabato (lower Miocene-lower Pliocene), Cagayan-Isabella, and Quirino (upper Miocene-Pliocene); (6) Sultan Kudarat (upper Miocene-Pleistocene); and (7) Samar-Leyte (lower PliocenePleistocene) (fig. 1). In general, coal rank is directly related to the age of the deposits - for example, the Eocene coal is semianthracite and the Pliocene-Pleistocene coal is lignite.

Total coal resources in these 19 coal districts, which are compiled by the Geothermal and Coal Resources Development Division (GCRDD) of the Department of Energy of the Philippines, are estimated at a minimum of 2,268.4 million metric tonnes (MMT) (approximately 2.3 billion metric tones; see fig. 1). The largest resource (550 MMT) is the subbituminous coal in the Semirara (including Mindoro) coal district, and the smallest (0.7 MMT) is the lignite-subbituminous coal in the Quirino coal district. The combined lignite and subbituminous coal resources, using the classification by GCRDD and including Semirara and Surigao coal districts, are about 1,899.2 MMT, which make up about 84 percent of the total coal resources of the Philippines. The remaining resources are composed of bituminous and semi-anthracite coal.

The subbituminous coal of Semirara Island in the Mindoro-Semirara coal district (fig. 2) is known to contain coalbed methane (CBM), with the coal being comparable in gas content and adsorption isotherms to the coal of the Paleocene Fort Union Formation in the Powder River Basin in Wyoming, USA (Flores and others, 2005). As a consequence, the

\footnotetext{
${ }^{1}$ U.S. Geological Survey, Denver Colorado

${ }^{2}$ Philippine Department of Energy, Metro Manila, Philippines
}

presence of CBM in the Semirara coal led to the present study of determining the adsorption isotherms, or gas (CBM) holding or storage capacity, of coal beds of various ages from selected coal districts in the Philippines. Samples for the study were collected from the Batan Island, Catanduanes, Cagayan-Isabella, Cebu, Negros, Samar, Semirara, Cotabato, Surigao, and Malangas coalfield of the Zamboanga Sibuguey coal districts by five field geology teams from the GCRDD.

\section{Coal Geology of Studied Philippine Coal Districts}

The coals studied from Philippine coal districts vary in geologic age, coal rank, lithostratigraphy, and depositional environment. The structural settings also vary, from large to small, folded to faulted, downdropped basins and sub-basins some of which are bounded by mountain ranges. More importantly, the coal districts lie in small to large islands, some of which are parts of peninsulas. Locations of coal samples collected in the coal districts are shown in figure 2.

\section{Batan Island Coal District}

The coal sample in the Batan Island coal district was collected from the middle Miocene Bilbao Formation. The formation consists, from bottom to top, of (1) the Lower Limestone Member - buff-colored conglomeratic, coralline limestone with scattered lenses of carbonaceous sandstone, siltstone, and shale; (2) the Galicia Sandstone - coarse and locally conglomeratic sandstone; (3) the Coal Measure - brown sandstone and carbonaceous shale with interbedded coal beds; and (4) the Upper Limestone Member - massive gray to white limestone. These rocks are interpreted to be deposited in paralic and shallow marine environments. The Batan Island is a part of a group of islands in a southeast-trending peninsula of Luzon (fig. 2). The island is structurally deformed into synclines and anticlines disrupted by a fault in the middle part of the island. 


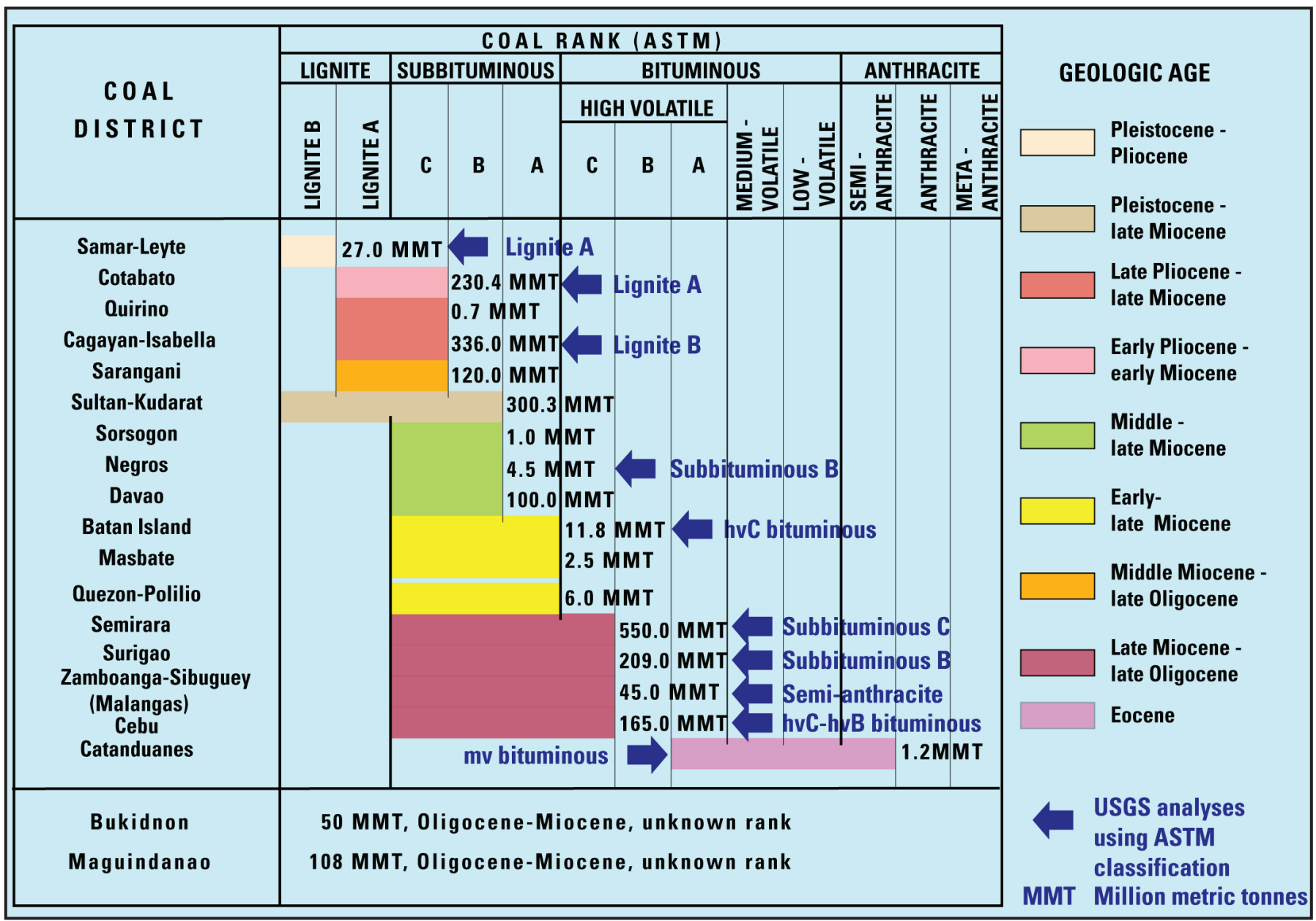

Figure 1. Coal districts of the Philippines containing lignite to semi-anthracite coal (rank determined by GRCDD using ASTM classification) in strata ranging from Eocene to Pleistocene in age. The coal samples (indicated by blue arrows) from 10 coal districts were re-analyzed for their apparent rank by the U.S. Geological Survey. The coal resources for each of the districts are indicated in million metric tonnes (MMT). Modified from Balce and others (2005).

\section{Catanduanes Coal District}

The coal sample in the Catanduanes coal district was collected from the Eocene Hitoma and Payo Formations. The formations consist of carbonaceous shale, siltstone, sandstone, and coal beds. The coals are in distinct beds, $0.3-1.5 \mathrm{~m}$ thick, and in stringers; those in the carbonaceous shales were deposited in a paralic environment. The coal measure is in a northeast-trending basin bounded by two northeast-trending faults. The beds are steeply dipping to almost vertical, having been deformed by faulting along both northeast and northwest trends (del Rosario and Pastor, 2005a). Catanduanes is an island, part of a group of islands in a southeast-trending peninsula of Luzon (fig. 2).

\section{Cagayan-Isabella Coal District}

The coal samples from Cagayan-Isabella coal district were collected in the Pliocene-Pleistocene Ilagan Formation, which contains interbedded marine shale and sandstone in the lower part and coarse marine sandstone and continental, coalbearing sandstone and conglomerate in the upper part. The coal beds, as much as $2.5 \mathrm{~m}$ thick (BHP Engineering, 1999), are part of a sequence that was deposited in marine and paralic environments. The coal district is located in the Cagayan Basin in northern Luzon (fig. 2), which is a semi-arcuate elongated valley bounded on the east by the Sierra Madre, on the west by the Cordillera Mountains, and on the southeast by the Caraballo Mountains.

\section{Cebu Coal District}

Coal samples from Cebu coal district were collected in the upper Oligocene Cebu Formation, upper Oligocene-lower Miocene Malubog Formation, and middle Miocene Calagasan Formation (Pendon and Tilos, 2005). These coal-bearing formations consist of interbedded sandstone, siltstone, and shale, and contain coal beds as much as $2 \mathrm{~m}$ thick. Some 


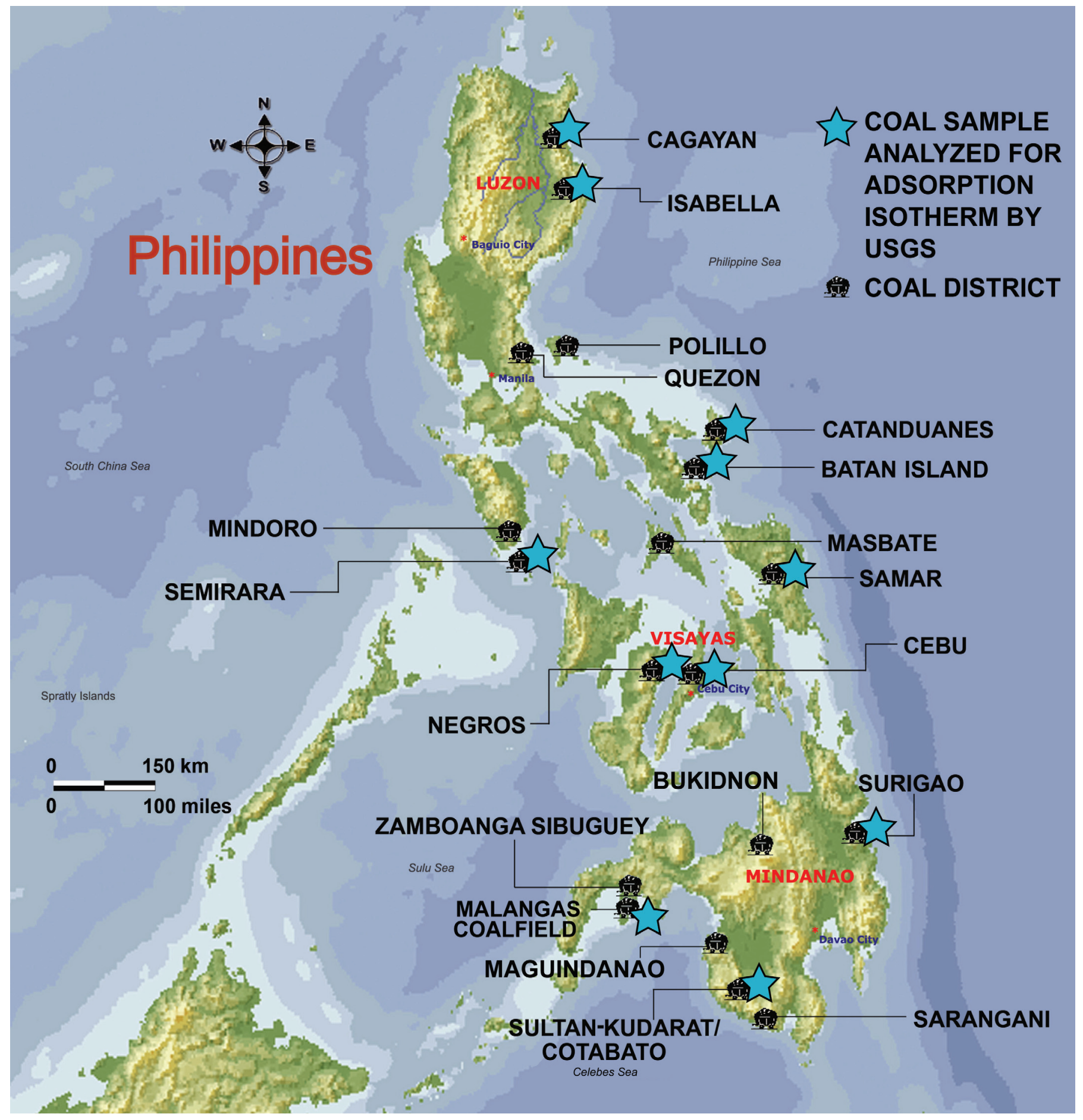

Figure 2. Locations of coal samples from various Philippine coal districts that were analyzed by the U.S. Geological Survey.

marine limestones are present indicating deposition in coastal paralic environments. Cebu is in the Visayas group of islands (fig. 2) in the south-central part of the Philippines. The island is mainly comprised of pre-Cretaceous-Oligocene basement rocks (for example, volcanics, schists, andesite, and diorite), which are exposed in faulted areas in the central part of the island. The younger coal-bearing formations are distributed along the margins of these basement rocks.

\section{Cotabato Coal District}

Coal samples in the Cotabato coal district were collected in the southern part of Mindanao (fig. 2), in the Oligocene Siloay Formation (Papasin and Pendon, 2005). This coal-bearing formation is informally named the Daguma Cotabato coal deposits by Daguma Agro-Minerals, Inc. ("Daguma"), which holds the Coal Operating Contract for this area. Daguma described the 
unit as consisting of interbedded sandstone, mudstone, shale, limestone, and coal beds. The coal beds, ranging in thickness from 8 to $17.5 \mathrm{~m}$, are in four coal zones within a 220-m-thick stratigraphic interval that lies in the southwestern part of the Cotabato Basin, which is a large basin encompassing most of central Mindanao (fig. 2). The basin was infilled mainly by siliciclastics, metasediments, and metavolcanics. The western part of the basin is bounded by the Daguma uplift.

\section{Negros Coal District}

The coal sample from Negros coal district is from the lower Miocene Macasilao Formation (Pendon and Tilos, 2005), which consists of interbedded shale, claystone, sandstone, conglomerate, coal, and limestone beds deposited in terrestrial environments interrupted by short periods of marine trangression and paralic environments. The coal, as much as $5 \mathrm{~m}$ thick, is in moderately dipping beds (20 degrees). The district is in the boot-shaped island of Negros, directly west of Cebu in Western Visayas (fig. 2) and the coal deposits are located in the northern, northeastern, south-central, and southwestern parts of the island.

\section{Samar (Excluding Leyte) Coal District}

The coal samples from Samar coal district were collected in the Oligocene-lower Miocene Bagacay Formation (del Rosario and Pastor, 2005b). The formation consists of interbedded shale, siltstone, sandstone, and coal beds. The coal beds, which are as much as $3 \mathrm{~m}$ thick and flat-lying, contain shale partings. Samar Island is situated in the easternmost part of the Visayas (fig. 2) and the coal areas are in the southern part of the island.

\section{Semirara (Excluding Mindoro) Coal District}

The coal samples in the Semirara part of the SemiraraMindoro coal district were collected in the lower-middle Miocene Semirara Formation. The formation is divided into a Lower Member consisting of sandstone, siltstone, and coal beds; a Middle Member consisting of predominantly sandstone with minor beds of mudstone and coal beds; and an Upper Member consisting of argillaceous limestone. Coal beds are as much as $20 \mathrm{~m}$ thick and are mined for steam coal by Semirara Coal Corporation. The coal-bearing units are overlain by a marine limestone (Pliocene Buenavista Formation), which indicates probable deposition on a low-lying coastal plain drained by rivers followed by a marine transgression. The Semirara part of the coal district, which is situated south of Mindoro Island (fig. 2), includes the Panian, Himalian, and Unong coalfields. These coalfields are in a series of anticlines or an anticlinorium displaced by a series of southwest-northeast trending normal faults. Two of these faults are major displacements that subdivide the island into three blocks, each containing a coalfield.

\section{Surigao Coal District}

Coal samples in the Surigao coal district were collected in the upper Oligocene-lower Miocene Pamaypayan Formation, which is a sequence of sandstone, siltstone, mudstone, and coal beds occupying a small basin in the eastern part of Mindanao (fig. 2).

\section{Zamboanga Sibuguey Coal District}

Coal samples in the Malangas coalfield of the Zamboanga Sibuguey coal district, located in the western part of Mindanao (fig. 2), were collected in the Lalat Member of the lower Miocene Lumbog Formation. This formation consists of lithic sandstone interbedded with subordinate mudstone, carbonaceous shale and mudstone, and coal beds. The coal beds, which are mined underground, range in thickness from 0.6 to $4.3 \mathrm{~m}$. The Lalat Member was deposited in fluvial and paralic environments, which were inundated intermittently by shallow marine transgressions. Strata in the Malangas coalfield are highly folded, faulted, and intruded by igneous rocks (for example, microdiorite) that locally baked the coal and surrounding rocks.

\section{Methods of Sampling}

Coal samples were selectively collected in the following coal districts by the listed personnel of GCRDD: (1) CagayanIsabella - Ramon F. Papasin, Elmer A. Altomea, and Federico Cuaresma; (2) Catanduanes/Samar - Rogelio A. del Rosario and Michael Pastor; (3) Cebu/Negros - Ronaldo R. Pendon and Elizabeth N. Tilos; (4) South Cotabato/Sultan Kudarat - Ronaldo R. Pendon and Ramon F. Papasin; and (5) Surigao del Sur/Bislig - Ruel T. Malapitan, Armando S. Malapitan, and Benjamin R. Mortos. The samples were collected during fieldwork from July to September, 2005.

A total of seventeen coal samples were collected from outcrops and underground active and abandoned mines (figs. 3, 4). Fresh outcrop samples were obtained by digging trenches or test pits, 1-2 m deep, from which (fig. 5) 1 to 2 $\mathrm{kg}$ of coal were collected. To retain their inherent moisture content, preparation for shipment to laboratory consisted of double bagging the coal sample, putting wet tissue in the plastic bags, and wrapping. Seven coal samples were collected from cores drilled in the Semirara coal district (figs. 7, 8).

The seventeen coal samples collected by GCRDD personnel were shipped by overnight carrier to the USGS in Denver, Colorado, USA for coal quality analyses and adsorption isotherms. The USGS then sent 250 to $300 \mathrm{~g}$ of each coal sample to a commercial testing laboratory for coal quality determination. Upon return of the analytical results, apparent ranks were calculated following the procedures of the American Society for Testing and Materials (ASTM, 1998; standards section D $388-98$ ). In addition, a sealed 200- to 300-g sample was sent to 
a commercial laboratory for high-pressure methane adsorption analysis (see Adsorption Isotherm section). Samples with duplicate apparent ranks were not submitted for isotherm analysis. Of the 17 samples collected by GRCDD personnel, 14 isotherms were determined.

In addition to the seventeen coal mentioned above, seven samples were obtained from drill holes by the Semirara Mining Corporation (SMC) in the Panian and Himalian coalfields, also for high-pressure adsorption isotherm analysis. These samples, which were collected in conjunction with the SMC staff in Semirara Island, have the apparent rank of subbituminous $\mathrm{C}$ coal; analytical results were reported earlier by Flores and others (2005) and are averaged for the present report (see below).

\section{Discussion of Results}

Results of the coal quality and high-pressure methane adsorption isotherm analyses of coal samples are described in the Appendix; coal rank and adsorption isotherm data are listed in table 1.

\section{Coal Quality}

Coal quality and chemistry (tables 2,3 ) were determined from analyses of moisture content; proximate and ultimate analyses; forms of sulfur; heat value (Btu); free swelling index; moist, mineral-matter free Btu; dry, mineral-matter-free fixed carbon; apparent rank (following ASTM classification); apparent specific gravity; and random vitrinite reflectance $\left(\mathrm{R}_{\mathrm{o}}\right)$. Analyses performed in conjunction with the adsorption isotherm included equilibrium moisture, ash yield, heat value (Btu), moist, mineral-matter-free Btu, dry mineral-matter-free fixed Btu, and apparent rank. Both the moist, mineral-matterfree Btu and dry mineral-matter-free fixed carbon were determined to estimate apparent rank of the coal. That is, above 69 (see fig. 9) on a dry mineral-matter-free fixed carbon, the apparent rank of the coal is estimated to be from high volatile A bituminous to meta-anthracite, whereas below 69 the apparent rank is estimated to range from lignite to high volatile B bituminous on moist, mineral-matter-free Btu.

The USGS judged the apparent rank of the coal samples to be higher than those estimated by the GRCDD; rank classifications by both GRCDD and USGS are shown in figure 1. The rank of coal samples from Samar-Leyte coal district was estimated by the USGS as lignite A, Batan Island coal district as high volatile $\mathrm{C}(\mathrm{hvC})$ bituminous, Cebu coal district as hvC-high volatile B (hvB) bituminous, and Zamboanga Sibuguey (Malangas coalfield) as semi-anthracite. The coal sample from the Isabella-Cagayan coal district is of lower rank, ranging from lignite A to lignite B based on the USGS estimate.

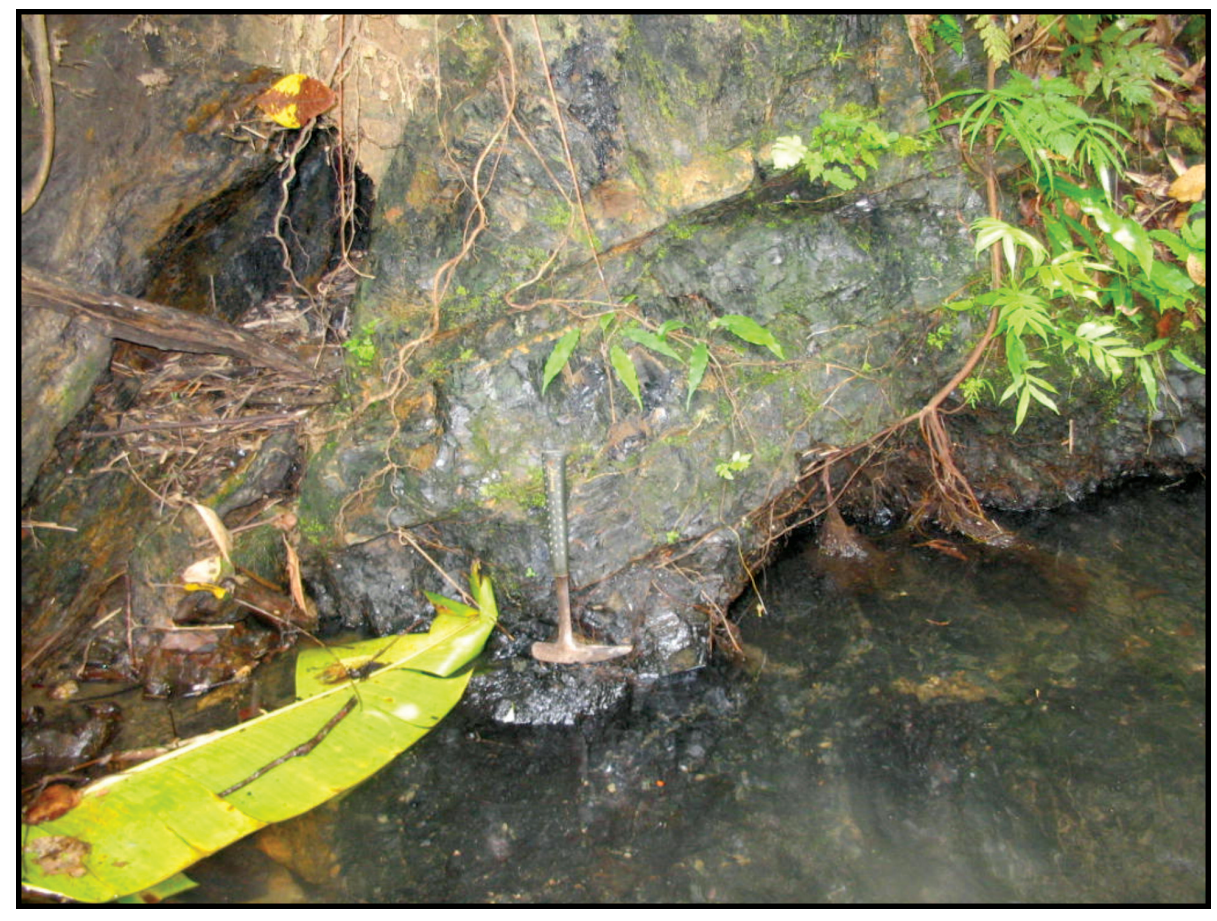

Figure 3. Photograph of a dipping coal-bed outcrop in Catanduanes coal district. Hammer handle is about $30.5 \mathrm{~cm}$ long. From del Rosario and Pastor (2005a). 


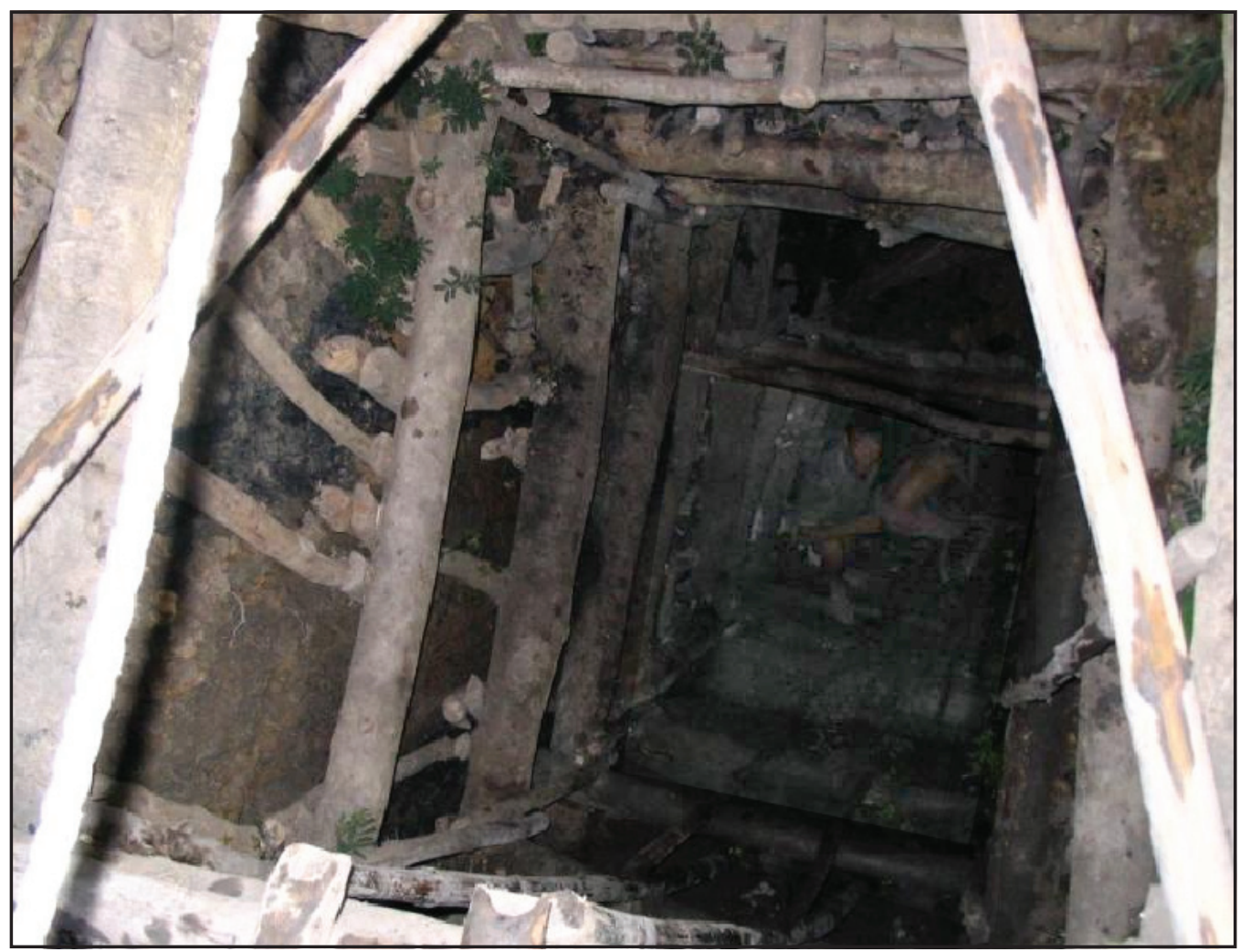

Figure 4. Photograph of an inclined shaft of an active underground mine in the Cebu coal district. From Pendon and Tilos (2005).

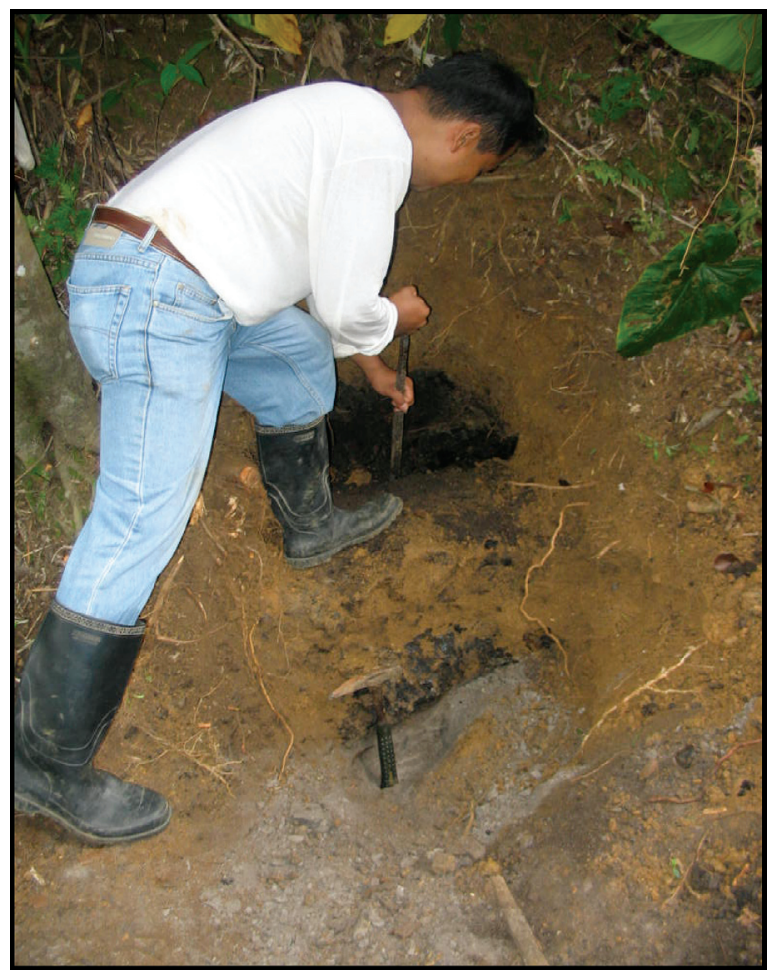

Figure 5. Photograph showing trenching at an outcrop in Catanduanes coal district for collecting coal samples. From del Rosario and Pastor (2005a). 


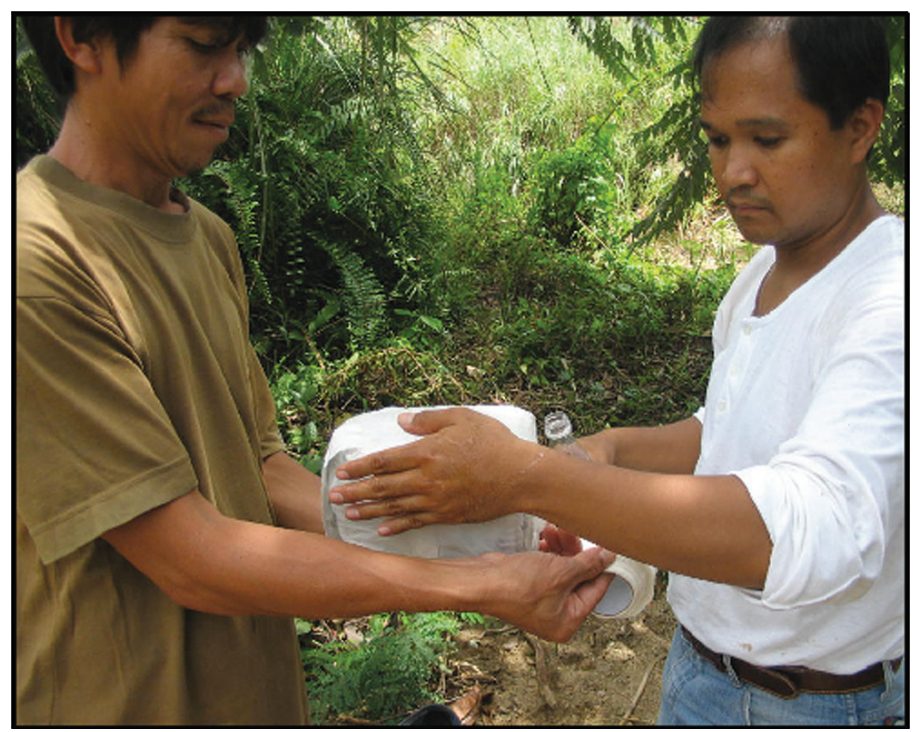

Figure 6. Photograph illustrating the preparation of a coal sample, immediately following collection, for shipment to laboratory.

Preparation consisted of double bagging the coal sample, putting wet tissue in the plastic bags, and wrapping for shipment. From del Rosario and Pastor (2005b).

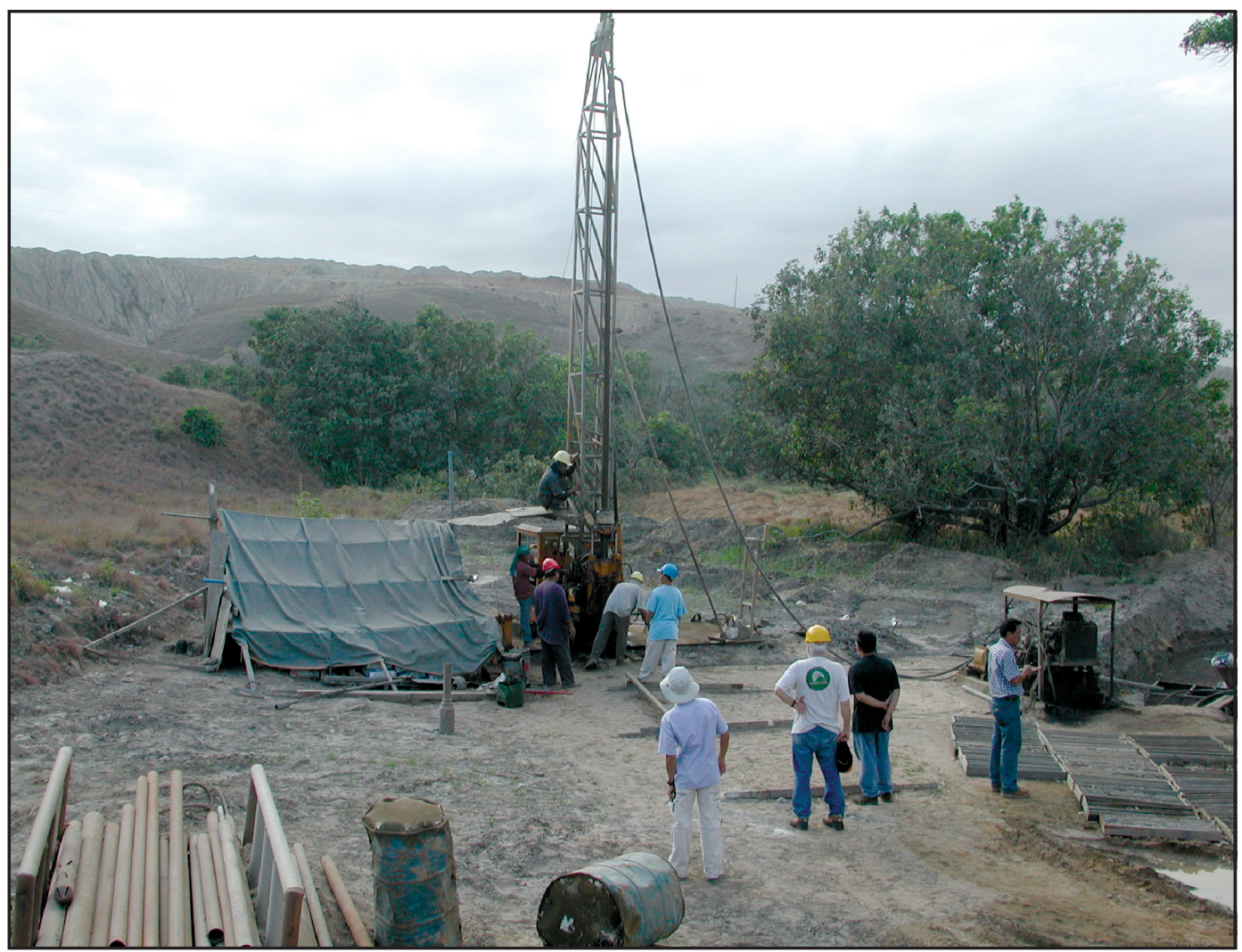

Figure 7. Photograph of drilling rig used by Semirara Mining Corporation to core coal in the Panian coalfield in the Semirara coal district. From Flores and others (2005). 


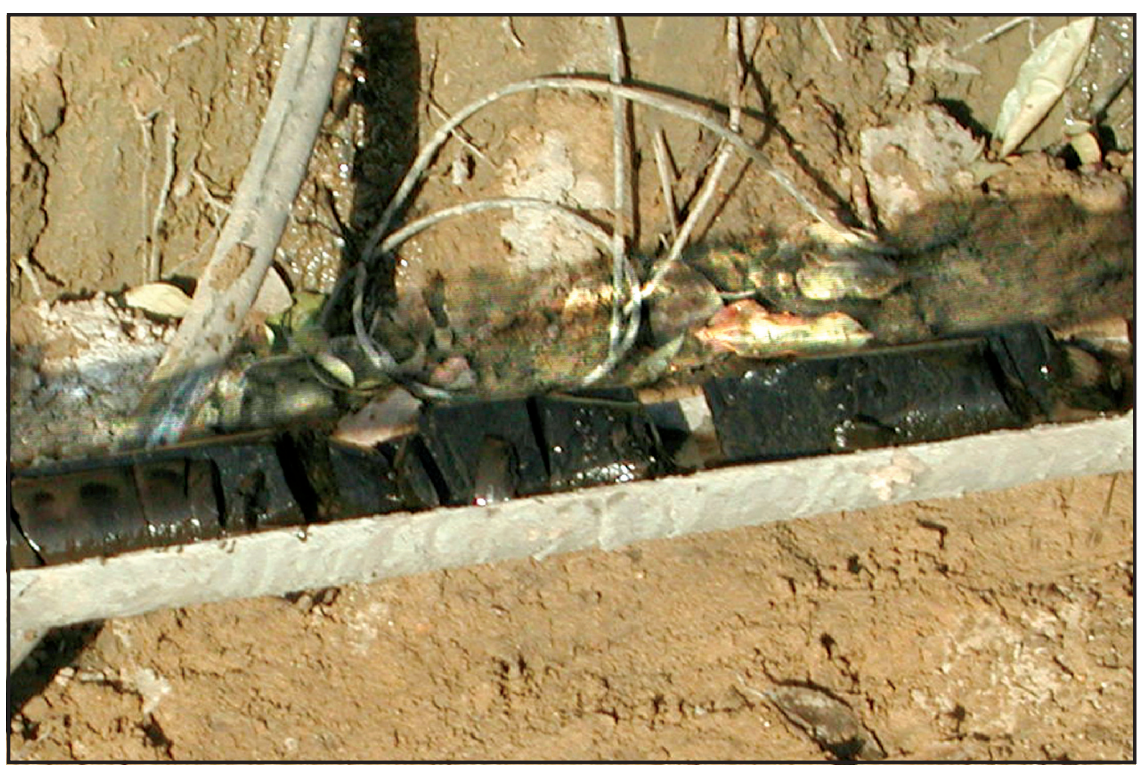

Figure 8. Coal core recovery from the Panian coalfield in the Semirara coal district. Adopted from Flores and others (2005).

In general, the equilibrium moisture of the coal samples appears to have been successfully retained during sample collection and shipment. Considering that they were collected from outcrops and coal mine shafts, the equilibrium moisture from the lignite samples, which ranges from 28.31 to 52.96 percent for the Cotabato and Cagayan-Isabella coal districts, respectively, appears normal for lignite rank (see table 2). However, equilibrium moisture of the lignite sample from Catanduanes, which is 7.06 percent, is anomalous. The equilibrium moisture of the high rank coal samples from the bituminous Cebu coal district (Danao 1, Argao 1, Toledo 1, Dalaguete 1) and the semi-anthracite Zamboanga (Malangas coalfield) coal district appears to be normal.

Ash yields of the lignite coal samples are generally low, ranging from 2.03 to 6.55 percent (lignite $\mathrm{B}$ through $\mathrm{A}$ ) except for the Catanduanes A coal sample, which contains 77.38 percent (table 2). A few of the high rank coal samples, such as the semi-anthracite Malangas coal (M-LA), contains 36.47 percent ash yield and the mvB bituminous Catanduanes coal (Catanduanes 1) contains 17.82 percent ash yield (table 2).

Four coal samples were tested for free-swelling properties, which may indicate the coking characteristic of the coal when burned as a fuel (ASTM, 1998) (table 3). Also, the test can be used to indicate the degree of oxidation of the coal. The free-swelling index ranges from 1.5 to 8 for three of the bituminous (hvBb-hvAb) coal samples (Argao 1, Toledo 1, Dalaguete 1) from Cebu coal district (table 3). The bituminous $(\mathrm{mvB})$ coal sample from the Catanduanes coal district exhibits a free-swelling index of 9, as determined from full-scale standard profiles (ASTM, 1998).

\section{Adsorption Isotherm}

Adsorption isotherm is defined by Mavor and Nelson (1977) as the quantitative relation, at constant temperature, that describes how the concentration of adsorbed phase molecules at an interfacial surface varies as a function of increasing system pressure. This relation is a measure of the sorbed gas storage capacity of the coal as a function of pressure (sorption isotherm). The most common model used to relate methane storage capacity to organic content of coal is the Langmuir isotherm. The ash yield and moisture content, which make up the inorganic content determined by the proximate analysis, influence the storage capacity of the coal. For example, the higher the ash yield and moisture content the lower the sorbed gas storage capacity of the coal.

The results of methane adsorption isotherm analyses of 15 coal samples from the Philippine coal districts arranged in alphabetical order are summarized in table 1 and described in detail in the Appendix. The relation between apparent rank, using dry, mineral-matter-free fixed carbon and moist mineral-matter-free Btu and the storage capacity of adsorbed methane in standard cubic feet per short ton ( $\mathrm{scf} / \mathrm{t})$ on an as-received basis of 9 of these coal samples is summarized in figure 9; only 7 representative coal samples were plotted from each different apparent rank. The plot of storage capacity of adsorbed methane for the coal samples may be defined by an average curve, which increases with coal rank from lignite to semi-anthracite (fig. 9). Average storage capacities, on an as-received basis (1) range from 7.14 standard cubic meters per metric tonne $(\mathrm{scm} / \mathrm{mt})(243.1 \mathrm{scf} / \mathrm{t})$ for the lignite in the 
Table 1. Summary of apparent rank and Langmuir parameters of Philippine coal samples. N.D., did not determine high-pressure methane adsorption.

\begin{tabular}{|c|c|c|c|c|}
\hline \multirow{2}{*}{$\begin{array}{l}\text { Philippine } \\
\text { coal districts }\end{array}$} & \multirow{2}{*}{ Sample name ${ }^{1}$} & \multirow{2}{*}{ Apparent rank ${ }^{2}$} & \multicolumn{2}{|c|}{$\begin{array}{l}\text { Langmuir isotherm } \\
\text { parameters }\end{array}$} \\
\hline & & & Volume $^{3}$ & Pressure $^{4}$ \\
\hline Batan Island & BTN-01 & High volatile $\mathrm{C}$ bituminous & $10.05(342.0)$ & $8.52(1235.7)$ \\
\hline Cagayan-Isabella & Cagayan Valley 1 & Lignite B & $7.14(243.1)$ & $4.51(653.6)$ \\
\hline Catanduanes & Catanduanes 1 & Medium volatile bituminous & $30.12(1025.0)$ & $4.50(653.1)$ \\
\hline Catanduanes & Catanduanes A & Lignite B & $1.01(34.4)$ & $12.09(1753.6)$ \\
\hline Cebu & Danao 1 & High volatile $\mathrm{C}$ bituminous & N.D. & N.D \\
\hline Cebu & Argao 1 & High volatile $B$ bituminous & $21.4(728.0)$ & $6.05(877.9)$ \\
\hline Cebu & Toledo 1 & High volatile $\mathrm{A}$ bituminous & $18.92(644.0)$ & $4.53(656.9)$ \\
\hline Cebu & Dalaguete 1 & High volatile $\mathrm{B}$ bituminous & $16.19(550.8)$ & $5.32(771.2)$ \\
\hline Cagayan-Isabella & Isabella 1 & Lignite B & $1.94(65.9)$ & $7.38(1070.2)$ \\
\hline Cagayan-Isabella & Isabella 2 & Lignite B & N.D. & N.D. \\
\hline Negros & Calatrava 1 & Subbituminous B & $1.19(40.5)$ & $3.74(541.8)$ \\
\hline Samar & Hinabangan 1 & Lignite A & $6.76(230.1)$ & $16.20(2350.1)$ \\
\hline Samar & Hinabangan 2 & Lignite A & N.D. & N.D. \\
\hline Cotabato & South Cotabato 1 & Lignite A & $4.50(153.2)$ & $5.71(827.8)$ \\
\hline Surigao & Sicahoy Bislig 1 & Subbituminous B & $5.36(182.3)$ & $4.67(676.9)$ \\
\hline Zamboanga Sibuguey & M-LC & Semianthracite & $22.96(781.2)$ & $5.53(802.3)$ \\
\hline Zamboanga Sibuguey & M-LA & Semianthracite & $12.90(438.9)$ & 6.89(999.4) \\
\hline Semirara & Panian and Himalian & Subbituminous C & $5.17(175.76)$ & 8.66(1256.2) \\
\hline $\begin{array}{l}2 \text { Calculated using A } \\
\text { ASTM Standards } \\
{ }^{3} \text { Langmuir Volume i } \\
\text { is volume in standa } \\
{ }^{4} \text { Langmuir Pressure }\end{array}$ & $\begin{array}{l}\text { nitted by Energy } \\
\text { rican Society for } \\
\text { apter D 388-98. } \\
\text { Standard cubic r } \\
\text { cubic feet per sh } \\
\text { megapascal per }\end{array}$ & $\begin{array}{l}\text { ource Development } \\
\text { ting and Materials, } 19 \\
\text { ers per metric tonne, } \\
\text { ton. } \\
\text { uare centimeter, numb }\end{array}$ & $\begin{array}{l}\text { Annual Boc } \\
\text { iner in pare } \\
\text { in parenthe }\end{array}$ & $\begin{array}{l}\text { heses } \\
s \text { is }\end{array}$ \\
\hline
\end{tabular}


Table 2. Coal chemistry (moisture and proximate and ultimate analyses) for samples utilized in construction of the Philippine isotherm curve (see figure 9 ).

$$
\text { Moisture (percent) }
$$

$$
\text { Proximate analysis (percent) }
$$
Ultimate analysis (percent)

\section{Sample name}

Air dry Residual Total Equilibrium Ash yield $\begin{gathered}\text { Volatile } \\ \text { matter }\end{gathered}$ carbon $\begin{gathered}\text { Fixed } \\ \text { Hydrogen Carbon Nitrogen Sulfur Oxygen }\end{gathered}$

\begin{tabular}{|c|c|c|c|c|c|c|c|c|c|c|c|c|}
\hline BTN 1 & 3.86 & 3.57 & 7.29 & 6.06 & 13.76 & 42.92 & 36.03 & 5.52 & 60.24 & 1.12 & 0.30 & 19.06 \\
\hline Cagayan Valley 1 & 50.49 & 7.94 & 54.42 & 48.99 & 5.52 & 22.63 & 17.43 & 2.16 & 27.30 & 0.47 & 1.79 & 8.34 \\
\hline Catanduanes 1 & 2.77 & 0.66 & 3.41 & 2.23 & 17.82 & 20.34 & 58.43 & 3.92 & 69.18 & 1.39 & 0.52 & 3.76 \\
\hline Catanduanes A & 6.27 & 1.95 & 8.10 & 7.06 & 77.38 & 13.47 & 1.05 & 1.18 & 2.56 & 0.01 & 0.05 & 10.72 \\
\hline Danao 1 & 7.39 & 3.76 & 10.87 & 11.03 & 3.85 & 42.38 & 42.90 & 4.83 & 66.13 & 1.41 & 0.65 & 12.26 \\
\hline Argao 1 & 2.40 & 1.00 & 3.38 & 3.71 & 3.78 & 45.30 & 47.54 & 5.20 & 75.13 & 1.64 & 0.47 & 10.40 \\
\hline Toledo 1 & 2.11 & 0.26 & 2.36 & 1.81 & 7.30 & 42.53 & 47.81 & 4.97 & 74.75 & 1.63 & 3.76 & 5.23 \\
\hline Dalaguete 1 & 3.66 & 2.16 & 5.74 & 5.64 & 2.63 & 42.83 & 48.80 & 5.09 & 73.19 & 1.66 & 0.44 & 11.25 \\
\hline Isabella 1 & 56.77 & 7.24 & 59.90 & 27.07 & 2.03 & 21.07 & 17.00 & 2.07 & 26.49 & 0.43 & 0.23 & 8.85 \\
\hline Isabella 2 & 55.95 & 7.60 & 59.30 & 52.96 & 3.42 & 20.79 & 16.49 & 2.03 & 25.29 & 0.38 & 0.16 & 9.42 \\
\hline Calatrava 1 & 16.11 & 4.90 & 20.22 & 20.33 & 12.24 & 31.47 & 36.07 & 3.63 & 50.24 & 1.43 & 0.48 & 11.76 \\
\hline Hinabangan 1 & 34.48 & 4.83 & 37.64 & 37.02 & 6.55 & 30.59 & 25.22 & 3.52 & 38.22 & 0.61 & 0.94 & 12.52 \\
\hline Hinabangan 2 & 31.38 & 6.07 & 35.55 & 35.13 & 5.00 & 30.96 & 28.49 & 3.22 & 41.18 & 0.55 & 3.19 & 11.31 \\
\hline South Cotabato 1 & 43.40 & 5.90 & 46.74 & 28.31 & 3.58 & 27.35 & 22.33 & 2.79 & 35.66 & 0.42 & 0.35 & 10.46 \\
\hline Sicahoy Bislig 1 & 16.30 & 4.61 & 20.16 & 20.73 & 6.40 & 35.51 & 37.93 & 4.02 & 55.16 & 1.15 & 0.44 & 12.67 \\
\hline M-LC & 3.83 & 0.70 & 4.50 & 2.09 & 5.20 & 12.14 & 78.16 & 3.67 & 82.87 & 2.38 & 0.74 & 5.14 \\
\hline M-LA & 5.81 & 2.02 & 7.71 & 5.33 & 36.47 & 9.91 & 45.91 & 2.60 & 48.98 & 1.22 & 0.79 & 9.94 \\
\hline
\end{tabular}


Table 3. Coal chemistry (calorific value, free swelling index, apparent rank and specific gravity, forms of sulfur, and vitrinite reflectance) for samples utilized in construction of the Philippine isotherm curve (see figure 9).

\begin{tabular}{|c|c|c|c|c|c|c|c|c|c|c|}
\hline Sample number & $\begin{array}{l}\text { Calorific } \\
\text { value }^{1}\end{array}$ & $\begin{array}{c}\text { Free } \\
\text { swelling } \\
\text { index }^{2}\end{array}$ & $\begin{array}{c}\text { Calorific } \\
\text { value }^{1} \\
\text { (moist, } \\
\text { mineral- } \\
\text { matter- } \\
\text { free } \\
\text { basis) }\end{array}$ & $\begin{array}{c}\text { Fixed } \\
\text { carbon } \\
\text { (dry, } \\
\text { mineral- } \\
\text { matter- } \\
\text { free } \\
\text { basis) }\end{array}$ & 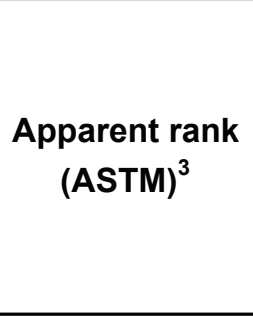 & $\begin{array}{c}\text { Apparent } \\
\text { specific } \\
\text { gravity } \\
\text { (grams per } \\
\text { cubic } \\
\text { centimeter) }\end{array}$ & Sulfate & f sulfur & Organic & $\begin{array}{c}\text { Random } \\
\text { Ro }^{4}\end{array}$ \\
\hline BTN 1 & 10,591 & 0.0 & 12,446 & 46.32 & $\mathrm{hvCb}$ & 1.35 & 0.01 & 0.07 & 0.22 & 0.58 \\
\hline Cagayan Valley 1 & 4,805 & 0.0 & 5,067 & 44.42 & lignite B & 1.57 & 0.02 & 1.30 & 0.47 & \\
\hline Catanduanes 1 & 12,002 & 9.0 & 14,883 & 75.72 & $m v b$ & 1.48 & 0.00 & 0.03 & 0.49 & \\
\hline Catanduanes A & 294 & 0.0 & 1,777 & 12.56 & lignite B & 2.55 & 0.02 & 0.03 & 0.00 & \\
\hline Danao 1 & 11,586 & 0.0 & 12,100 & 44.83 & $\mathrm{hvCb}$ & 1.39 & & & & \\
\hline Argao 1 & 13,403 & 3.0 & 13,987 & 49.62 & hvBb & 1.33 & & & & \\
\hline Toledo 1 & 13,577 & 8.0 & 14,869 & 52.47 & hvAb & 1.34 & & & & \\
\hline Dalaguete 1 & 12,914 & 1.5 & 13,302 & 50.28 & hvBb & 1.35 & & & & \\
\hline Isabella 1 & 4,505 & 0.0 & 4,600 & 44.90 & lignite B & 1.49 & 0.00 & 0.06 & 0.17 & \\
\hline Isabella 2 & 4,291 & 0.0 & 4,451 & 44.60 & lignite B & 1.56 & 0.00 & 0.01 & 0.15 & \\
\hline Calatrava 1 & 8,811 & 0.0 & 10,156 & 54.30 & sub B & 1.53 & 0.01 & 0.10 & 0.37 & \\
\hline Hinabangan 1 & 6,868 & 0.0 & 7,381 & 45.79 & lignite $A$ & 1.49 & 0.01 & 0.04 & 0.89 & \\
\hline Hinabangan 2 & 7,209 & 0.0 & 7,593 & 48.89 & lignite $A$ & 1.53 & 0.21 & 0.38 & 2.60 & \\
\hline South Cotabato 1 & 6,123 & 0.0 & 6,364 & 45.28 & lignite A & 1.48 & 0.00 & 0.02 & 0.33 & \\
\hline Sicahoy Bislig 1 & 9,633 & 0.0 & 10,352 & 52.09 & sub $B$ & 1.46 & 0.01 & 0.03 & 0.40 & \\
\hline M-LC & 13,785 & 0.0 & 14,629 & 87.23 & semianthracite & 1.39 & 0.01 & 0.28 & 0.45 & \\
\hline M-LA & 8,089 & 0.0 & 13,376 & 87.28 & semianthracite & 1.75 & 0.02 & 0.40 & 0.37 & \\
\hline
\end{tabular}

${ }^{1}$ Value is in British thermal units (Btu).

2 American Society for Testing and Materials (ASTM), 1998 Annual Book of ASTM Standards Chapter D 720-91

${ }^{3}$ ASTM Chapter D 388-98; subB = Subbituminous B coal, hvCb= High volatile $C$ bituminous coal,

$\mathrm{hvBb}=$ High volatile $\mathrm{B}$ bitumions coal, hvAb = High volatile A bituminous coal, $\mathrm{mvb}=$ Medium volatile bituminous coal

${ }^{4}$ Random vitrinite reflectance in oil (percent). 
Cagayan-Isabella coal district to $30.12 \mathrm{scm} / \mathrm{mt}(1,025.0 \mathrm{scf} / \mathrm{t})$ for the medium volatile bituminous in the Catanduanes coal district coal (table 1); (2) are as much as $22.96 \mathrm{scm} / \mathrm{t}$ (781.2 scf/t) for semi-anthracite coal from the Zamboanga coal district (Malangas coalfield; M-LC); and (3) range from 16.19 to $21.40 \mathrm{scm} / \mathrm{mt}$ ( 550.8 to $728 \mathrm{scf} / \mathrm{t}$ ) for bituminous (hvB through A) coal samples from the Cebu coal district (table 1).

Thus, the ability of the Philippine coal to store methane is a function of rank - that is, the storage capacity drops off considerably with decreasing rank. The plot/curve in figure 9 shows that lignite and subbituminous coal have similar methane storage capacities, which are from 100 to $200 \mathrm{scf} / \mathrm{t}$; these are higher than storage capacity of adsorbed methane for lignite in North Dakota, USA, which ranges from 1.0 to $5.4 \mathrm{scm} / \mathrm{mt}$ (31 to $173 \mathrm{scf} / \mathrm{t}$ ). This high gas storage capacity of adsorbed methane for Philippine lignite is an important consideration when evaluating the potential gas content of this coal.

Gas content of the lignite of Samar and Cagayan coal districts, which have a storage capacity of adsorbed methane ranging from 6.76 to $7.14 \mathrm{scm} / \mathrm{mt}(230.1$ to $243.1 \mathrm{scf} / \mathrm{t})$ on an as-received basis, may be best compared to the subbituminous $\mathrm{C}$ coal of the Semirara coal district, which has storage capacity of adsorbed methane from 4.5 to $6.3 \mathrm{scm} / \mathrm{mt}$ (145.1 to 202.2 scf/t) (Flores and others, 2005). The average total gas content of the subbituminous $\mathrm{C}$ coal in the Semirara coal district reported by Flores and others (2005) was measured from 28 canisters, which ranges from 0.26 to $1.42 \mathrm{scm} / \mathrm{mt}(0.01$ to $45.61 \mathrm{scf} / \mathrm{t}$ ). Thus, the Samar and Cagayan lignite, which record a higher storage capacity of adsorbed methane than the Semirara subbituminous coal, potentially contain more gas volume than the Semirara coal.

Flores and others (2005) reported that 28 Semirara coal samples cored at depths of 150 to $300 \mathrm{~m}$ (450 to $900 \mathrm{ft}$ ) have the same gas content $(0.5-0.9 \mathrm{~cm} / \mathrm{mt}$ or $15-30 \mathrm{scf} / \mathrm{t})$ as the CBM-producing Paleocene Fort Union Formation coal reservoirs in the Powder River Basin (PRB), Wyoming, USA at the same depths. In addition, comparison of the adsorption isotherms of the subbituminous $\mathrm{C}$ coal in the Semirara coal district and PRB indicates gas storage capacity of the Semirara coal to be above the average storage capacity of the PRB coal (fig. 10).

\section{Potential Coalbed Methane Resources}

Potential CBM resources in the Philippine coal districts can be estimated from the volumes of coal resources and their gas storage capacities. For the 10 districts that were studied, such estimates of CBM-in-place resources were made based on their Langmuir isotherm parameters (table 1), apparent coal rank (as assigned by the USGS, fig.1), and an assumed gas saturation of 100 percent (the ideal gas-holding capacity). CBM-in-place resources were estimated for the other coal districts on the basis of their coal rank and by extrapolating from the known adsorbed methane (Langmuir isotherm) from the studied districts. Results of these estimates are illustrated in figure 11, which shows the combined totals (exclusive of the Bukidnon and Maguindanao districts, as explained below) to range from10,317 MMCM to as much as 16,416 MMCM.

\section{Estimates from Studied Coal Districts}

Estimates of CBM resources in the studied coal districts are summarized as follows:

1. Lignite coal in the Samar-Leyte, Cotabato, and CagayanIsabella coal districts, which totals as much a 593.4 MMT (fig. 1), potentially stores as much as 3,620 million cubic meters (MMCM) of methane resources (fig. 1). Of this total, the Cagayan-Isabella coal district accounts for as much as 2,400 MMCM, and the Cotabato coal district accounts for 1.037 MMCM (fig. 11).

2. Subbituminous coal, which aggregates as much as 763.5 MMT in Negros, Semirara (including Mindoro), and Surigao coal districts (fig. 1) potentially holds or stores as much as 4,486 MMCM of methane resources, the bulk of it $(4,481 \mathrm{MMMCM})$ in the Semirara and Surigao districts (fig. 11).

3. Bituminous coal deposits, which are as much as 178 MMT in Batan Island, Catanduanes, and Cebu coal districts (fig. 1), potentially store as much as 3,685 MMCM of methane resources, most of it in the Cebu coal district where a tragic gas explosion occurred in a mine in December, 2005 (The Philippine Star, p. A-29).

4. Semi-anthracite coal, which is as much as $45 \mathrm{MMT}$ coal resources (Fig. 1), in the Zamboanga Sibuguey coal district, or most specifically in the Malangas coalfield, stores from 580 to 1,033 MMCM (fig. 11). This coal district has historically had coal mine explosions, which indicate that the coal contains gas (Balce and others, 2005).

5. Total CBM-in-place resources, based on a storage capacity that assumes 100 percent gas saturation, for the lignite to semi-anthracite Philippine coal in the studied coal districts range from 9,763 to 12,824 MMCM (fig. 11).

\section{Estimates From Other Coal Districts}

Coal deposits, which were not studied in the Bukidnon, Davao, Maguindanao, Masbate, Quezon-Polilio. Quirino, Sarangani, Sorsogon, and Sultan-Kudarat coal districts, contain as much as 688.5 MMT of coal resources (fig. 1). Coal rank ranges from lignite $\mathrm{B}$ to subbituminous $\mathrm{A}$; however, the rank for the Bukidnon and Maguindanao coal is unknown, so no CBM-in-place resources were estimated. The CBM-inplace resource estimates (fig. 11) based on ideal gas storage capacity, range from nearly $555 \mathrm{MMCM}$ to a maximum of 3,592 MMCM (fig. 11), to which should be added the amounts in the Bukidnon and Maguindanao districts when calculated. 


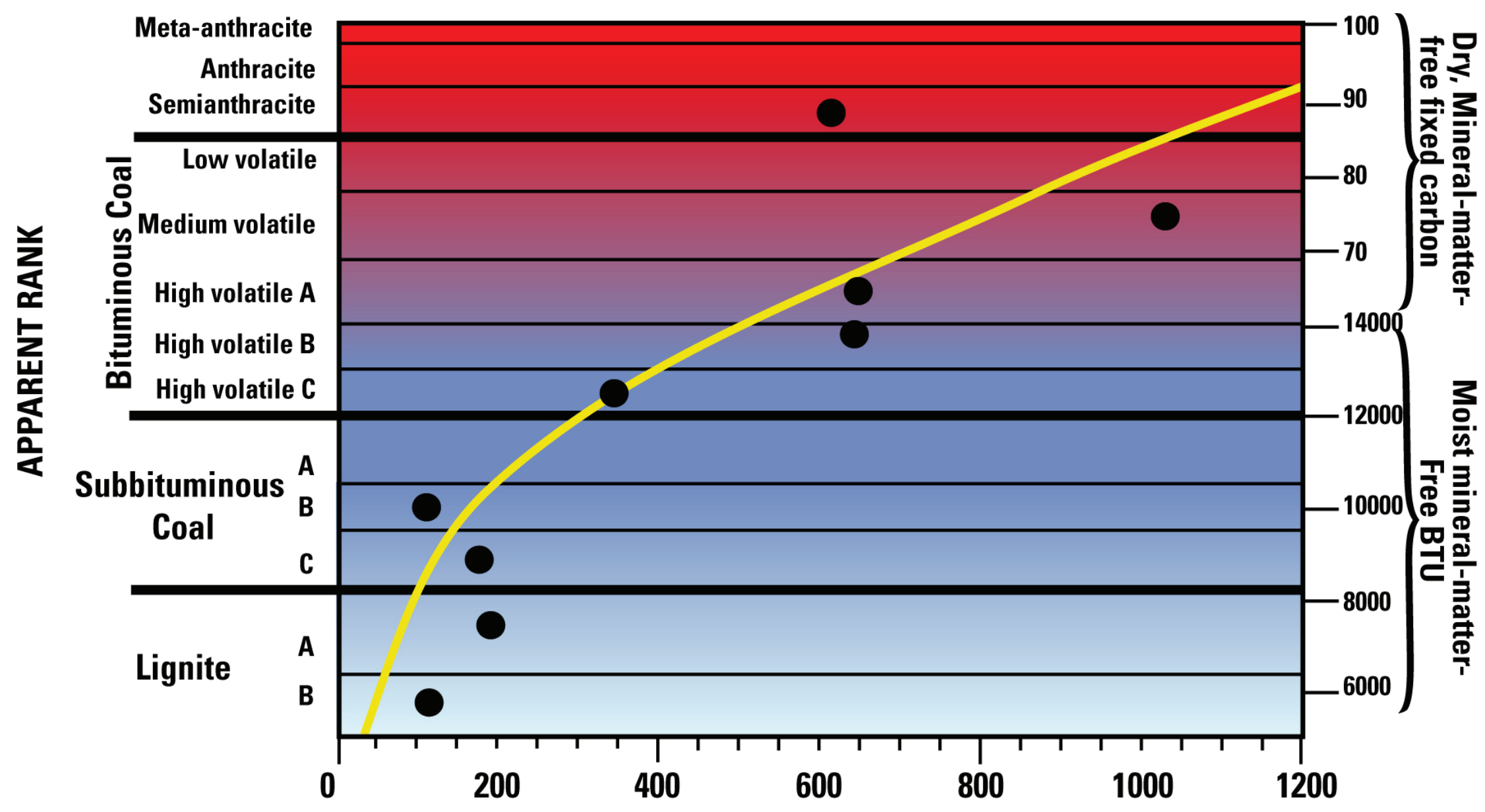

\section{ADSORBED METHANE (IN STANDARD CUBIC FEET PER SHORT TON AND ON AN AS-RECEIVED BASIS)}

Figure 9. Plot of adsorbed methane versus apparent rank of Philippine coal samples. Curve (yellow) defines average storage capacity of adsorbed methane. 


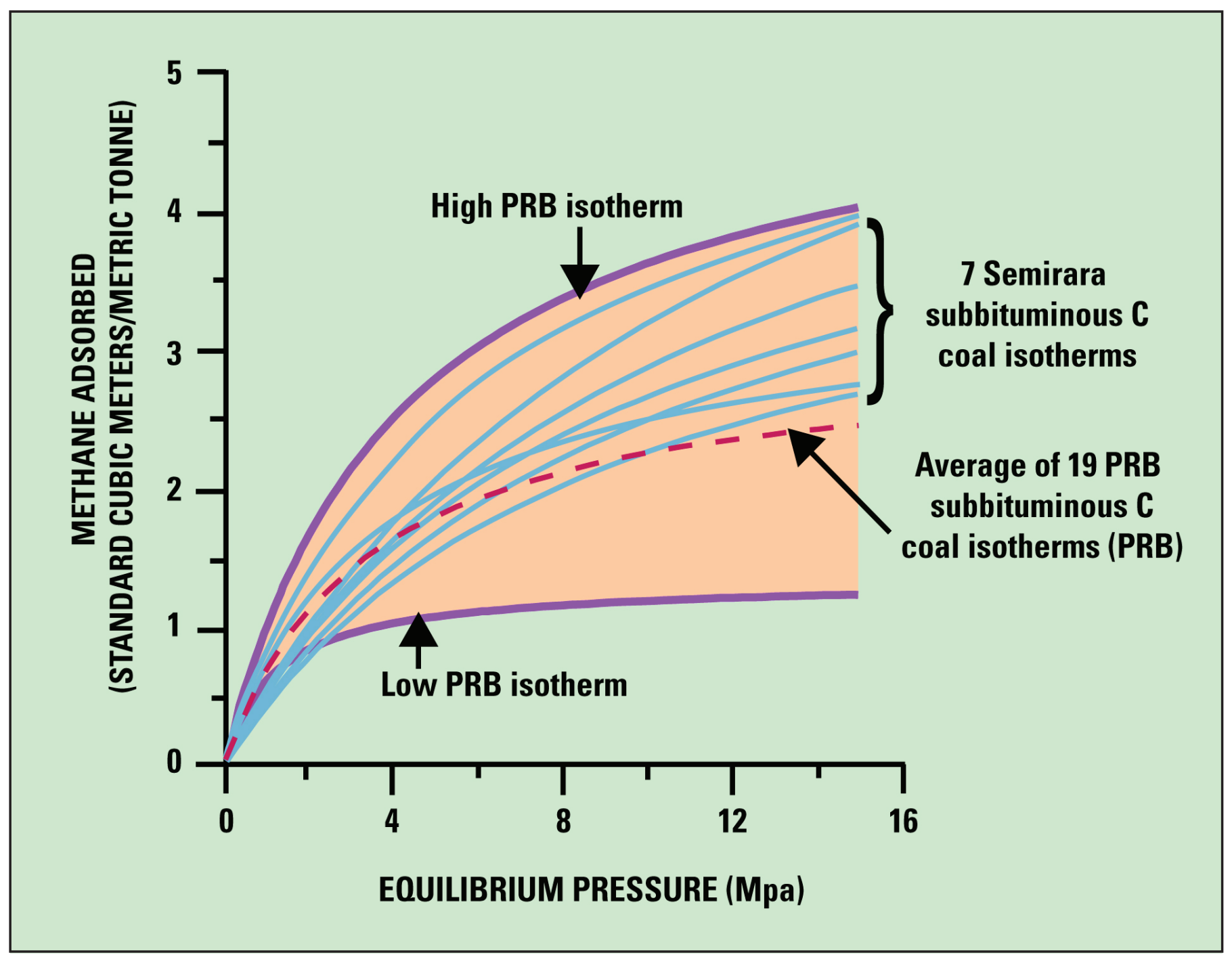

Figure 10. Plot of adsorption isotherms versus equilibrium pressure of coal samples in the Semirara coal district and in the Powder River Basin (PRB), Wyoming, USA. From Flores and others, 2005. 


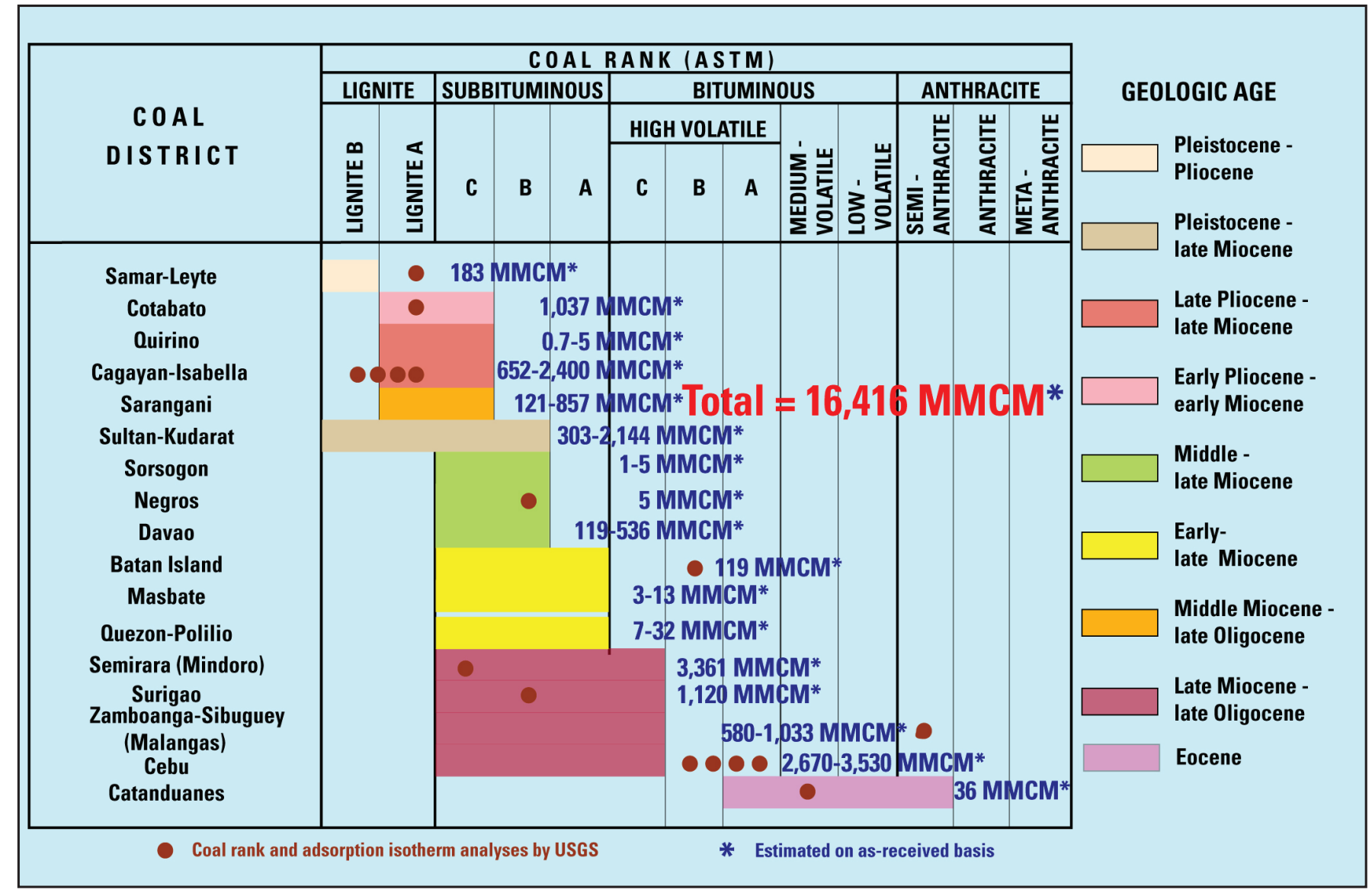

Figure 11. The potential minimum coalbed methane in-place resources (in million cubic meters, MMCM) estimated for Philippines coal districts based on ideal gas storage capacity (100 percent gas saturation) of the studied coal samples. Modified from Balce and others, 2005). 


\section{Recommendations for Future Study}

The high storage capacity of adsorbed methane is based on the adsorption isotherm analyses of various rank coals in the Philippines that were sampled from outcrops and mine shafts, which may have lost some inherent bed moisture before being analyzed. Thus, it is recommended that future coal samples be collected under better controlled conditions such as from core holes. Coal samples should be collected in the coal districts that were not included in the present study (for example, Davao, Quezon-Polilio, Masbate, Mindoro, Sorsogon, Sultan-Kudarat, Sarangani, and Quirino) for more complete evaluation of resources. Additionally, there should be replicate sampling of coal from the studied districts in order to double-check the results. It is further recommended that all future coal samples be desorbed for gas content in order to more fully assess the Philippine CBM resources.

\section{References Cited}

ASTM, 1998: Annual Book of American Society for Testing and Materials Standards, Chapter D 388-98 and 720-91, p. 174-199.

Balce, G.R., Flores, R.M., Stricker, G.D., Papasin, R.F., Pendon, R.R., Taganas, R.G., other Energy Resource Management Board Team Members, and San Jose, E.S., 2005, Potential coalbed methane resources in the Philippines: GEOCON 2005, Minerals and Energy Resources for Philippine Progress: Geological Society of the Philippines Annual Conference, Dec. 7-9, 2005, Makati, Manila: CDRom, file:///Volumes/MY_DISC/papers/4a_balce_flores_ frames.html, 5 p.,

BHP Engineering, 1999, Pre-feasibility study for Isabella coal project; for PNOC Exploration Corporation and Cogentrix Energy, Inc.: BHP Service Companies, Makati, Metro Manila, $18 \mathrm{p}$.

del Rosario, R.A., Jr., and Pastor, M.S., 2005a, Sorsogon and Catanduanes travel report:, Geothermal and Coal Resources Development Division of the Department, Energy Resources Development Board of Energy of the Philippines, 4 p.

del Rosario, R.A., Jr., and Pastor, M.S., 2005b, Samar travel report:, Geothermal and Coal Resources Development Division of the Department, Energy Resources Development Board of Energy of the Philippines, 5 p.

Flores, R.M., Stricker, G.D., Baquiran, G.B., Jimenez, T.M., Jr., Ammugauan, J.G., Gayondata, E.A., Papsin, R.F., and Pendon, R.R., 2005, Predicting coalbed gas production on Semirara Island, Philippines, from coalbed methane paradigms in the Powder River Basin, United States: GEOCON 2005, Minerals and Energy Resources for Philippine Progress: Geological Society of the Philippines Annual
Conference, Dec. 7-9, 2005, Makati, Manila: CD-Rom, file://Nolumes/MY_DISC/papers/4a_flores_et al_frames. html, $5 \mathrm{p}$.

Mavor, M., and Nelson, C.R., 1977, Coalbed reservoir gasin-place analysis: Gas Research Institute, GRI Report No. GRI-97/0263, 108 p.

Papasin, R.F., and Pendon, R.R., 2005, Travel report on the field validation of Daguma Agro-Minerals, Inc., drilling accomplishments and verification of coal occurrence in Barangay Kalibuhan, Palimbag, and Sultan Kudarat: Geothermal and Coal Resources Development Division, Energy Resources Development Board of the Department of Energy of the Philippines, $4 \mathrm{p}$.

Pendon, R.R., and Tilos, E.N., 2005, Travel report on the quarterly monitoring of Coal Operating Contract - Exploration and coal bed methane sampling in Cebu Province and Negros occidental: Geothermal and Coal Resources Development Division, Energy Resources Development Board of the Department of Energy of the Philippines, 6 p.

Manuscript approved for publication March 3, 2006

Published in the Central Region, Denver, Colorado

Edited by W.R. Keefer

Graphics by Carol Olson and Jonah Sullivan

Photocomposition and design by Mari L. Kauffmann

(Contractor, ATA Services) 


\section{Appendix}

The following reports on high-pressure methane adsorption, consisting of figures and tables of data, are taken verbatim from R.M.B. Earth Science Consultants Ltd., Delta, British Columbia, Canada, and have not been edited or reviewed for conformity with U.S. Geological Survey standards or nomenclature. The analyzed samples were supplied by the authors. 


\title{
High Pressure Methane Adsorption Analyses
}

\author{
BTN-01, Cagayan Valley 1, \\ Catanduanes 1, Catanduanes A, \\ Argao 1, Toledo 1, \\ Dalaguete 1, Isabella 1, \\ Calatrava 1, Hinabancan 1, \\ South Cotabato 1, Sicahoy Bislig 1, \\ M-LC, and M-LA
}

Analyses carried out by R.M.B. Earth Science Consultants Ltd. 327 Rosehill Wynd, Delta British Columbia, V4M 3L8 


\section{INTRODUCTION}

Fourteen coal samples were submitted for methane isotherm analyses by Dr. Romeo Flores.

The samples were designated: BTN-01, Cagayan Valley 1, Catanduanes 1 , Catanduanes A, Argao 1, Toledo 1, Dalaguete 1, Isabella 1, Calatrava 1, Hinabancan 1, South Cotabato 1, Sicahoy Bislig 1, M-LC, and M-LA. This report describes the methods and provides the analytical results.

\section{METHODS}

The samples were received wet/damp. They were ground to -60 mesh and placed in an equilibrium moisture bath for a period of 20 days to confirm equilibrium moisture. A two gram split of each sample was used for duplicate moisture and ash analyses. A detailed description and overview of the adsorption measurement procedures are provided at the end of the Appendix.

\section{Results \\ Adsorption Analysis}

The adsorption analysis of the sample is summarized on the attached pages in both SI (International System of measurement; e.g. gram and centimeter) and Imperial (Imp.) (British Imperial System; e.g. pound and foot) units.

Note that Standard Temperature and Pressure (STP) in SI units is at $0^{\circ} \mathrm{C}$. In Imperial units standard (oil industry convention) STP is at a temperature of $60^{\circ} \mathrm{F}$. Reported pressures are absolute. 


\section{BTN-01}

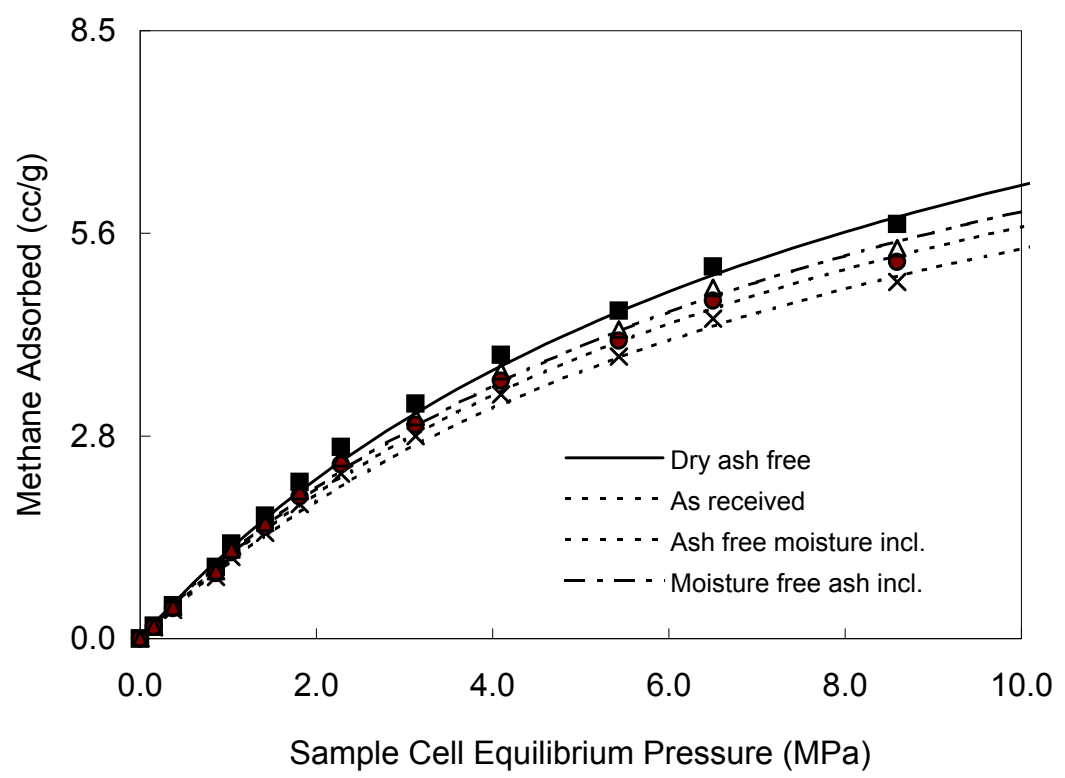

\begin{tabular}{|c|c|c|c|c|}
\hline \multirow{2}{*}{ Pressure } & \multicolumn{4}{|c|}{ Adsorbed gas (cc/g) } \\
\cline { 2 - 5 }$(\mathrm{MPa})$ & $\begin{array}{c}\text { As } \\
\text { Received }\end{array}$ & $\begin{array}{c}\text { Moisture } \\
\text { free ash } \\
\text { incl. }\end{array}$ & $\begin{array}{c}\text { ash free } \\
\text { moisture } \\
\text { incl }\end{array}$ & $\begin{array}{c}\text { Dry Ash } \\
\text { Free }\end{array}$ \\
\hline 0.154 & 0.15 & 0.17 & 0.16 & 0.18 \\
0.372 & 0.40 & 0.44 & 0.42 & 0.47 \\
0.862 & 0.86 & 0.94 & 0.91 & 1.00 \\
1.035 & 1.14 & 1.24 & 1.20 & 1.32 \\
1.419 & 1.47 & 1.61 & 1.55 & 1.71 \\
1.809 & 1.87 & 2.05 & 1.98 & 2.18 \\
2.279 & 2.29 & 2.51 & 2.42 & 2.67 \\
3.126 & 2.81 & 3.08 & 2.97 & 3.27 \\
4.097 & 3.40 & 3.72 & 3.59 & 3.95 \\
5.431 & 3.93 & 4.30 & 4.15 & 4.56 \\
6.500 & 4.46 & 4.88 & 4.70 & 5.18 \\
8.590 & 4.96 & 5.43 & 5.24 & 5.77 \\
10.290 & 5.32 & 5.83 & 5.62 & 6.19 \\
& & & \\
\hline
\end{tabular}

\begin{tabular}{|l|c|c|c|c|}
\hline & $\begin{array}{c}\text { As } \\
\text { Received }\end{array}$ & $\begin{array}{c}\text { Moisture } \\
\text { free ash } \\
\text { incl. }\end{array}$ & $\begin{array}{c}\text { Ash free } \\
\text { moisture } \\
\text { incl }\end{array}$ & $\begin{array}{c}\text { Dry Ash } \\
\text { Free }\end{array}$ \\
\hline Vol. (cc/g) & 10.05 & 11.01 & 10.61 & 11.69 \\
Pressure (MPa) & 8.52 & 8.52 & 8.52 & 8.52 \\
\hline
\end{tabular}

SUMMARY OF ADSORPTION ANALYSES SI UNITS

Isotherm Temperature:

Goodness of fit of Langmuir regression:

$28.0^{\circ} \mathrm{C}$

$\%$ Ash $=\mathbf{5 . 3 0}$

$\%$ Moisture $=8.68$

Density $(g / c c)=1.312$ 


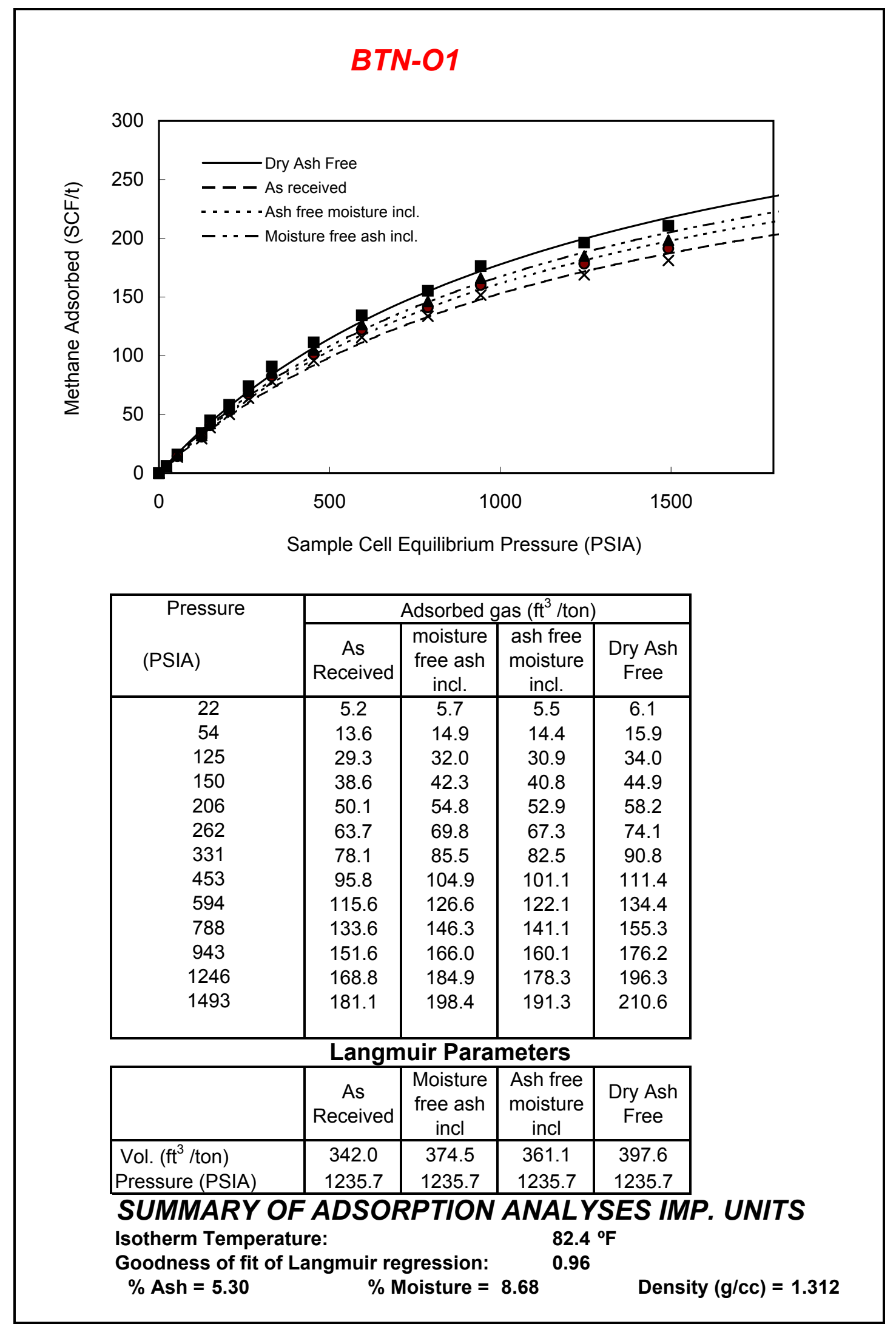


Adsorption Langmuir Plot

Batan Island

Sample BTN-01

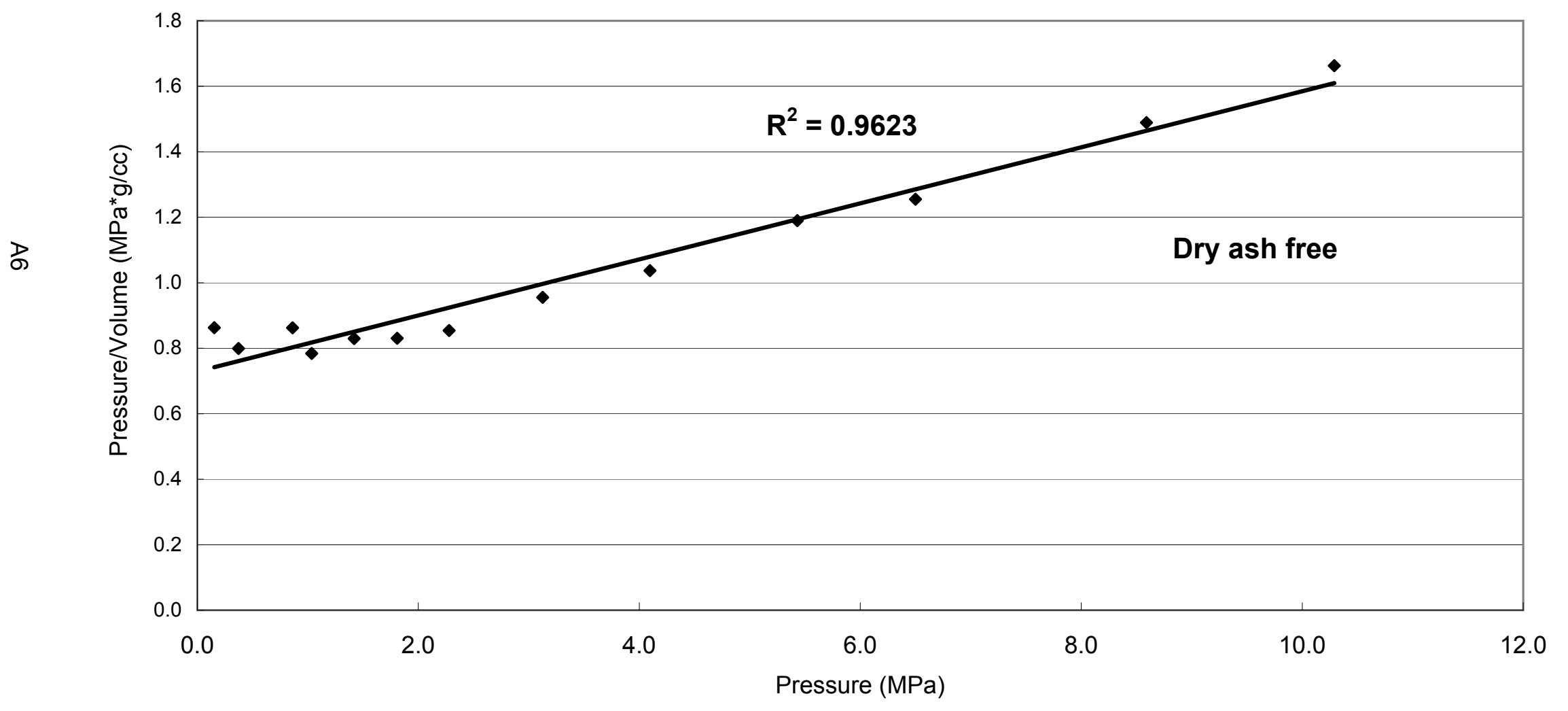




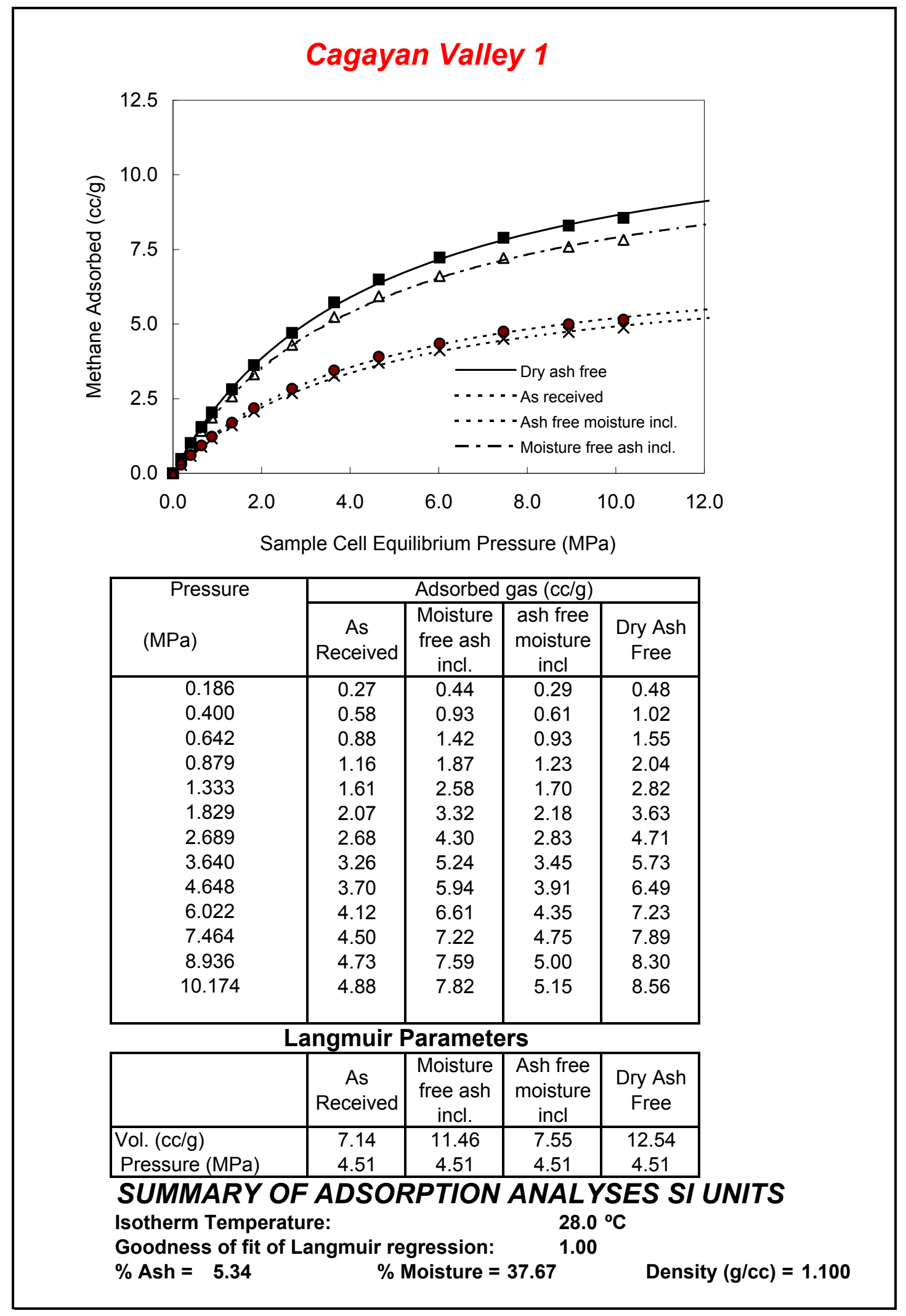




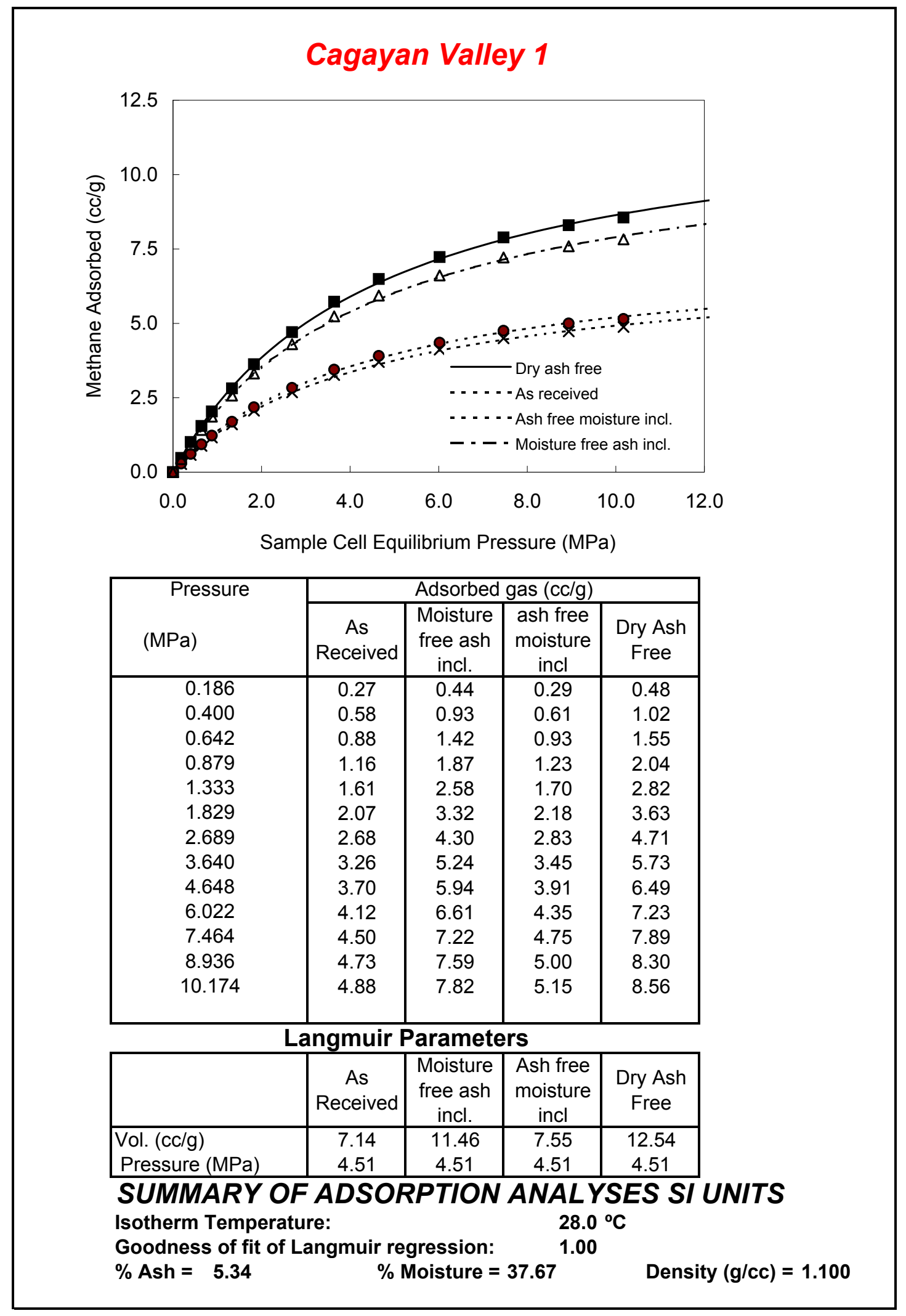


Adsorption Langmuir Plot

Cagayan-Isabella

Sample Cagayan Valley 1

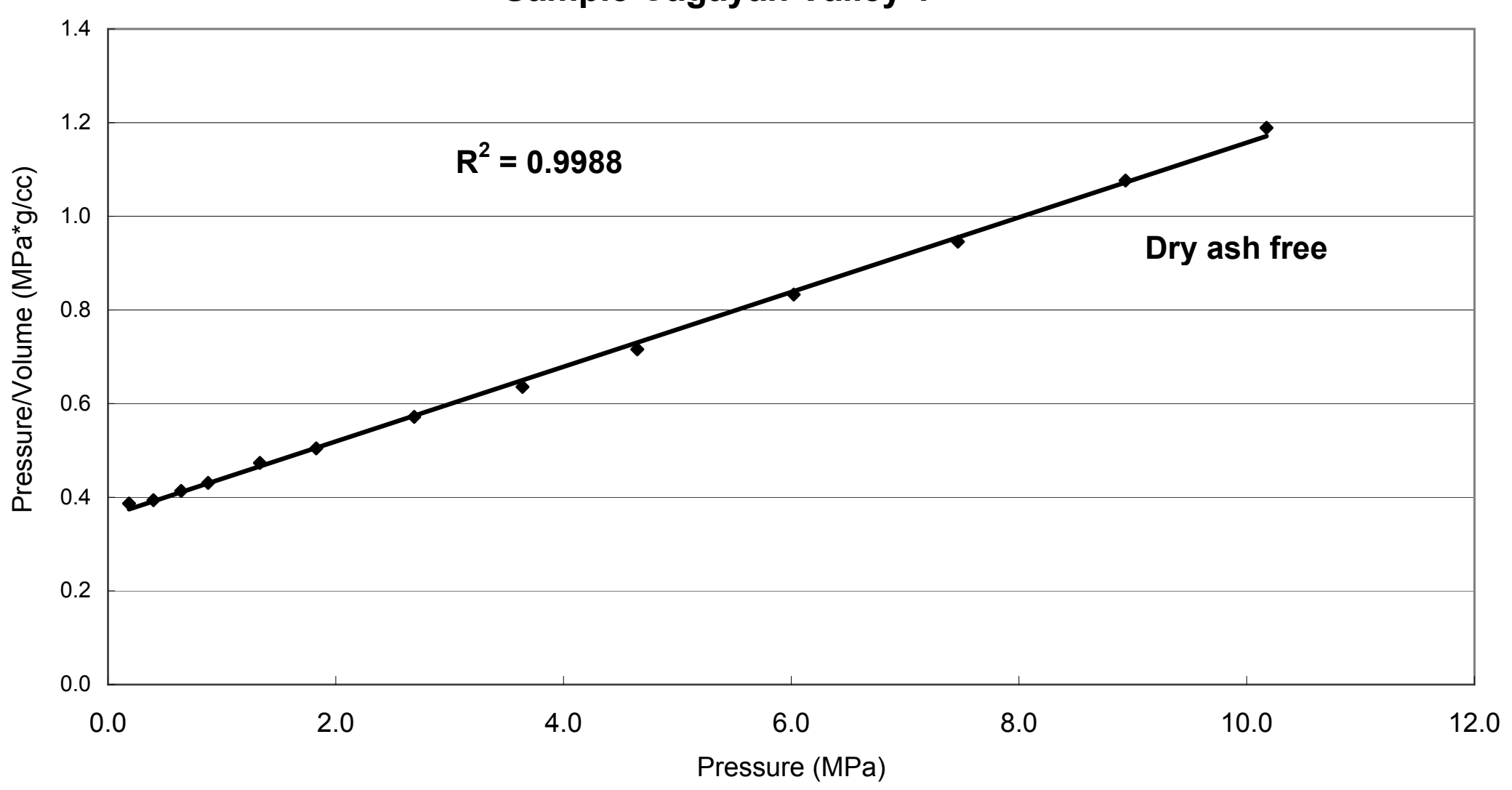




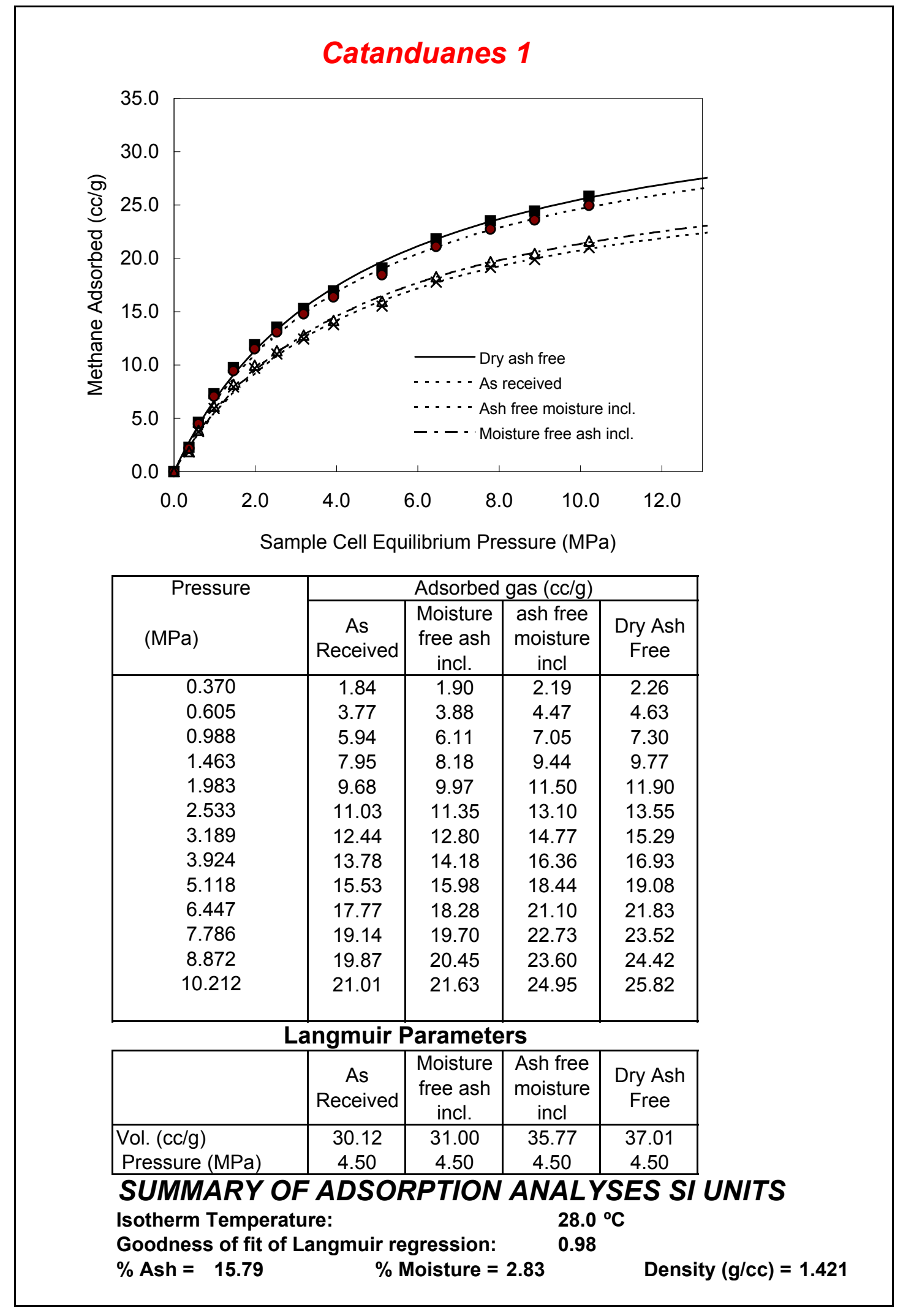




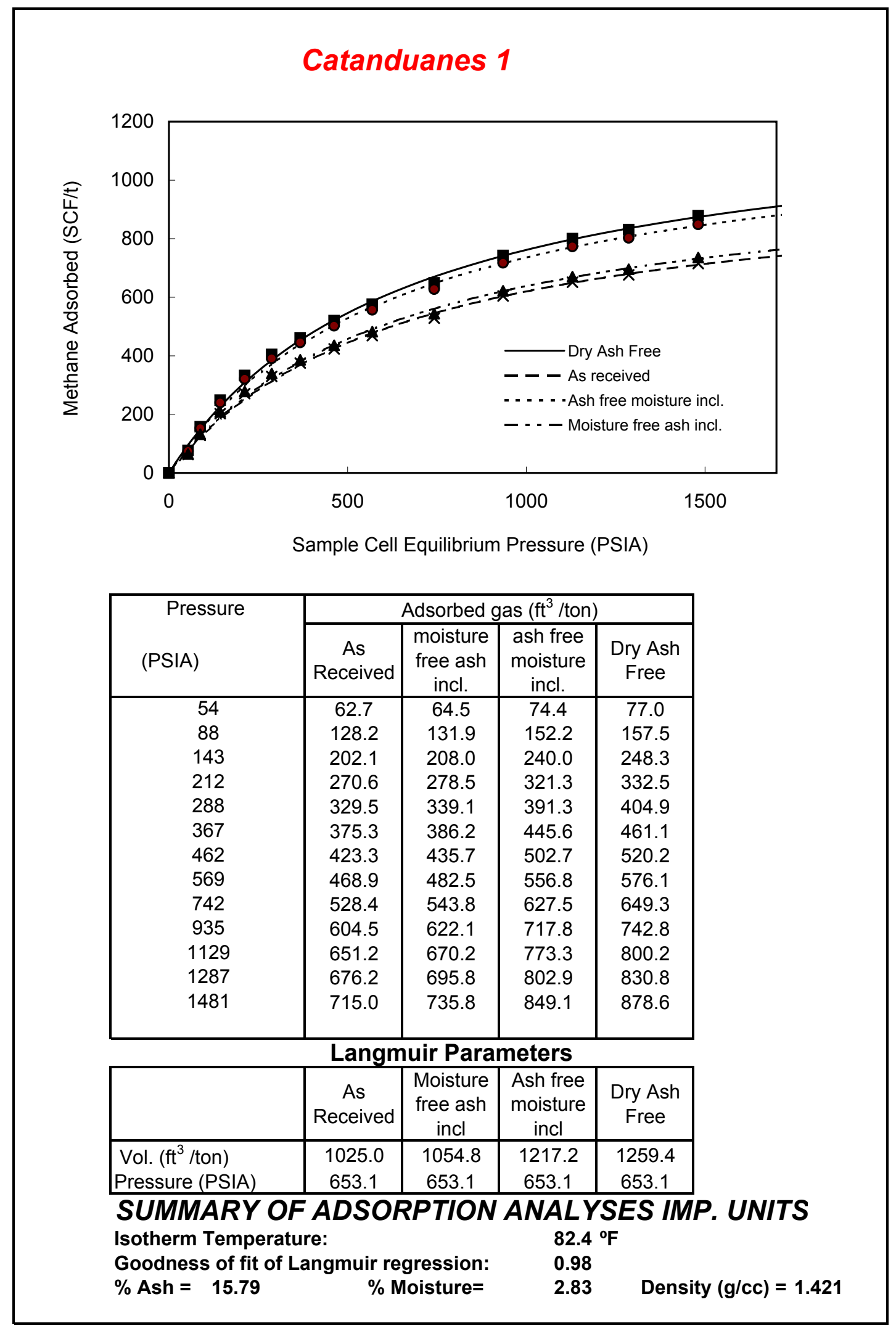




\section{Adsorption Langmuir Plot}

Catanduanes

Sample Catanduanes 1

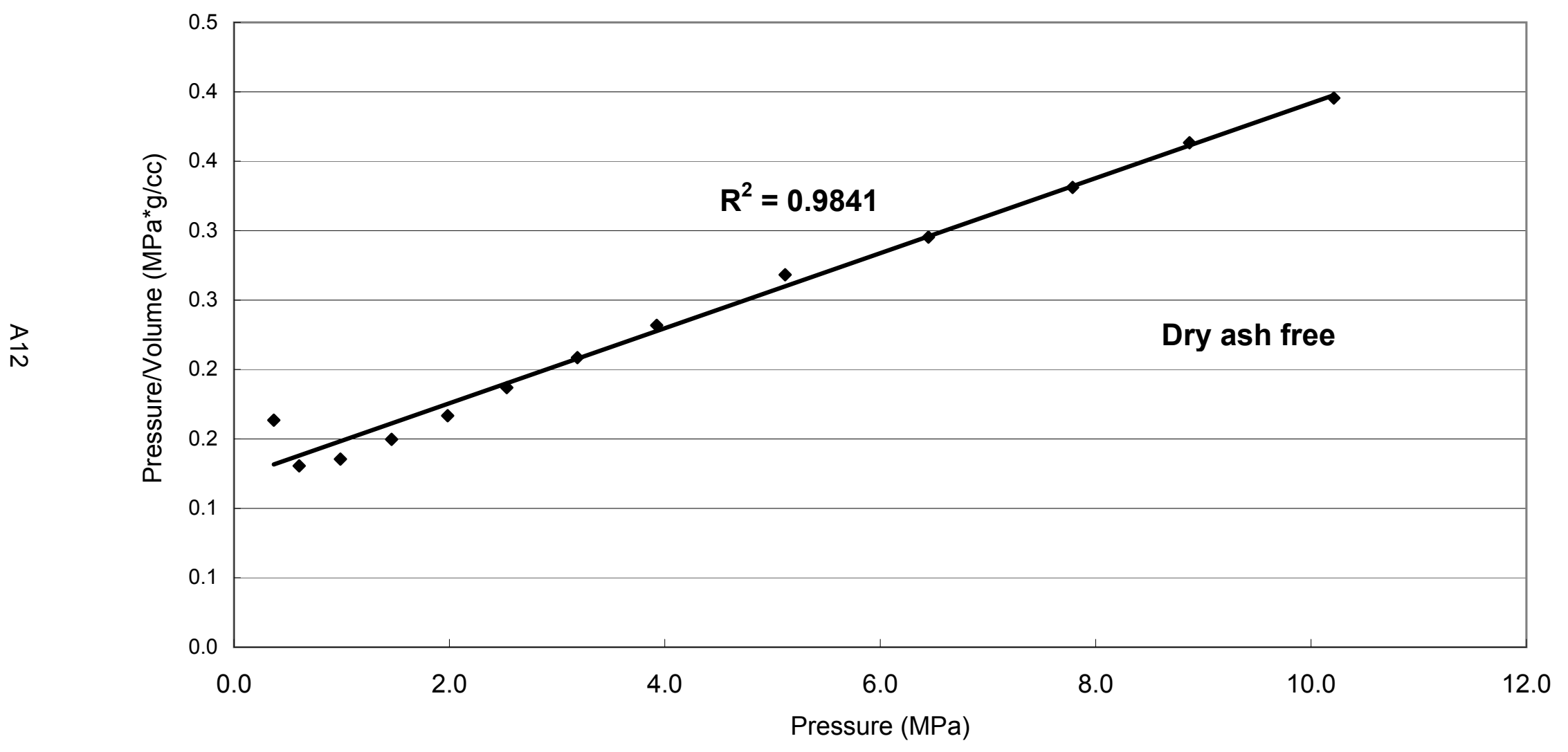




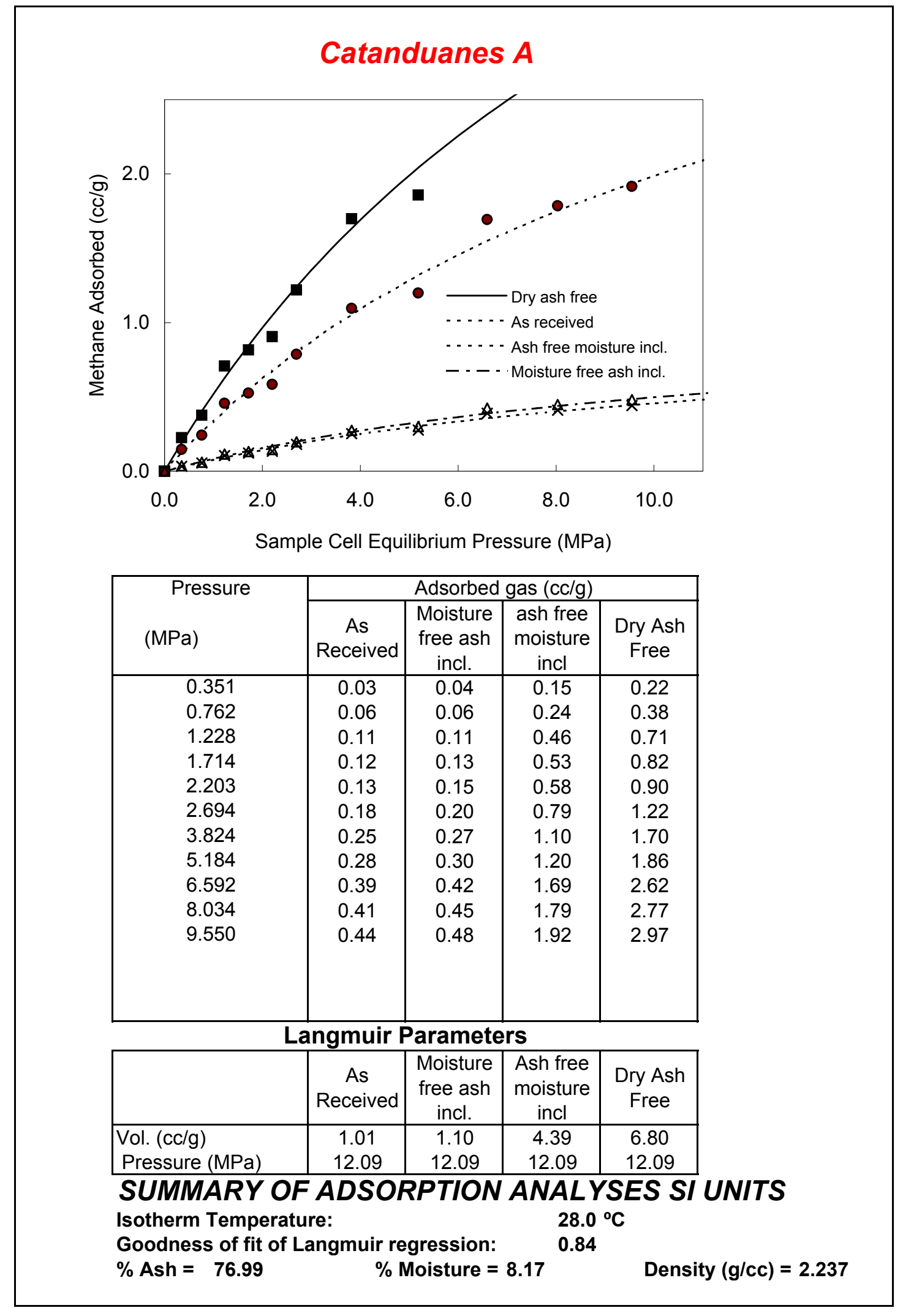




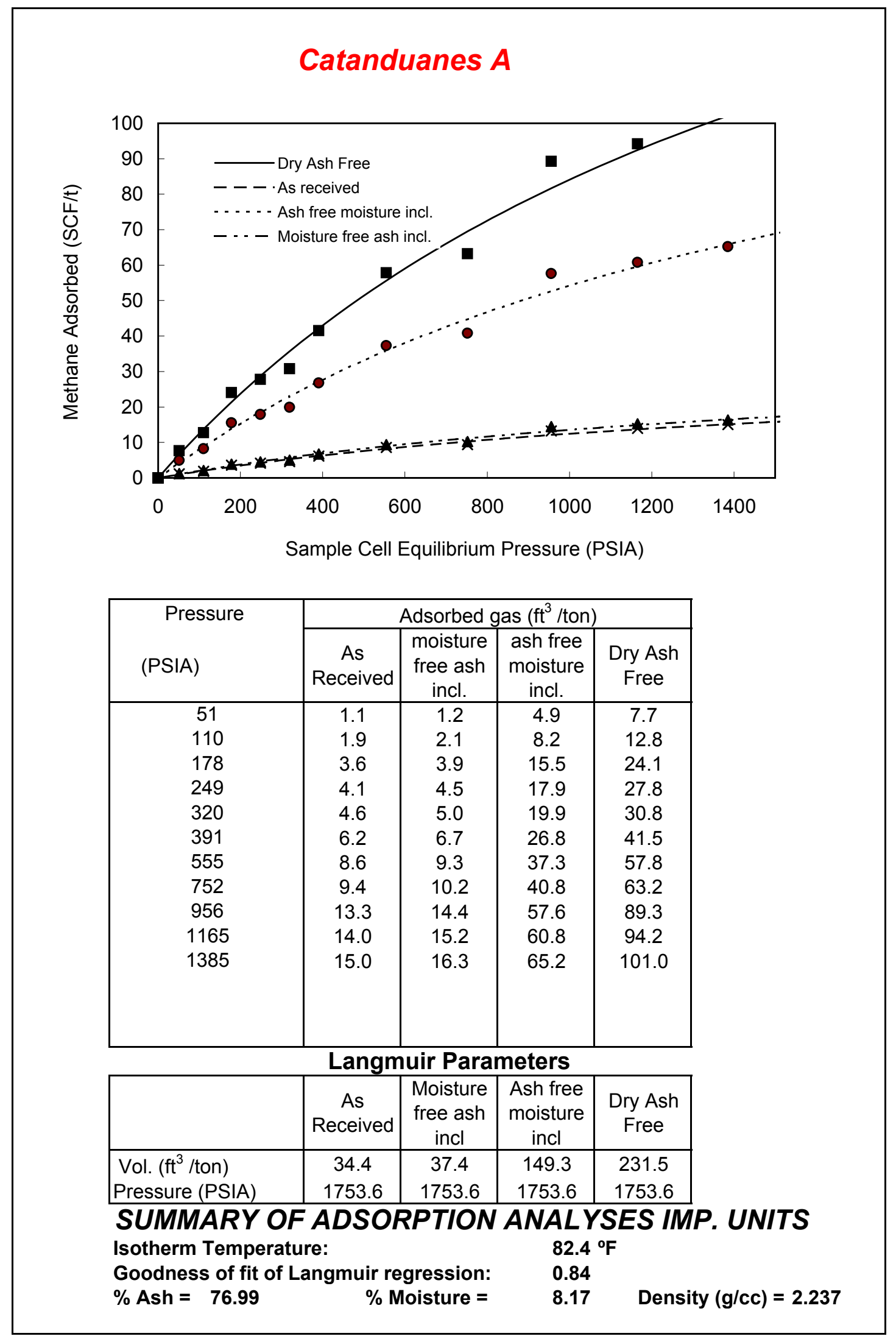




\section{Adsorption Langmuir Plot \\ Catanduanes}

Sample Catanduanes A

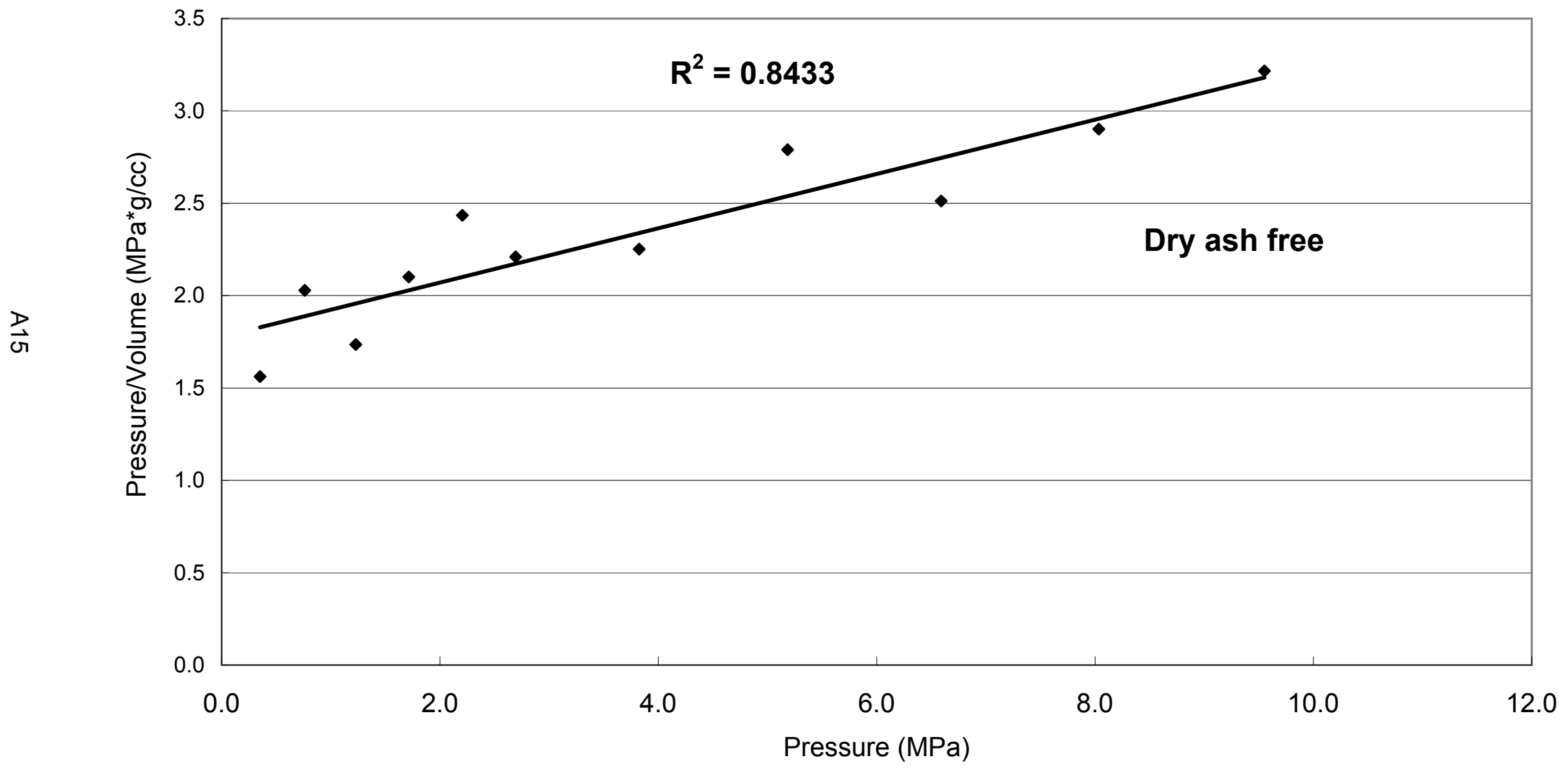




\section{Argao 1}

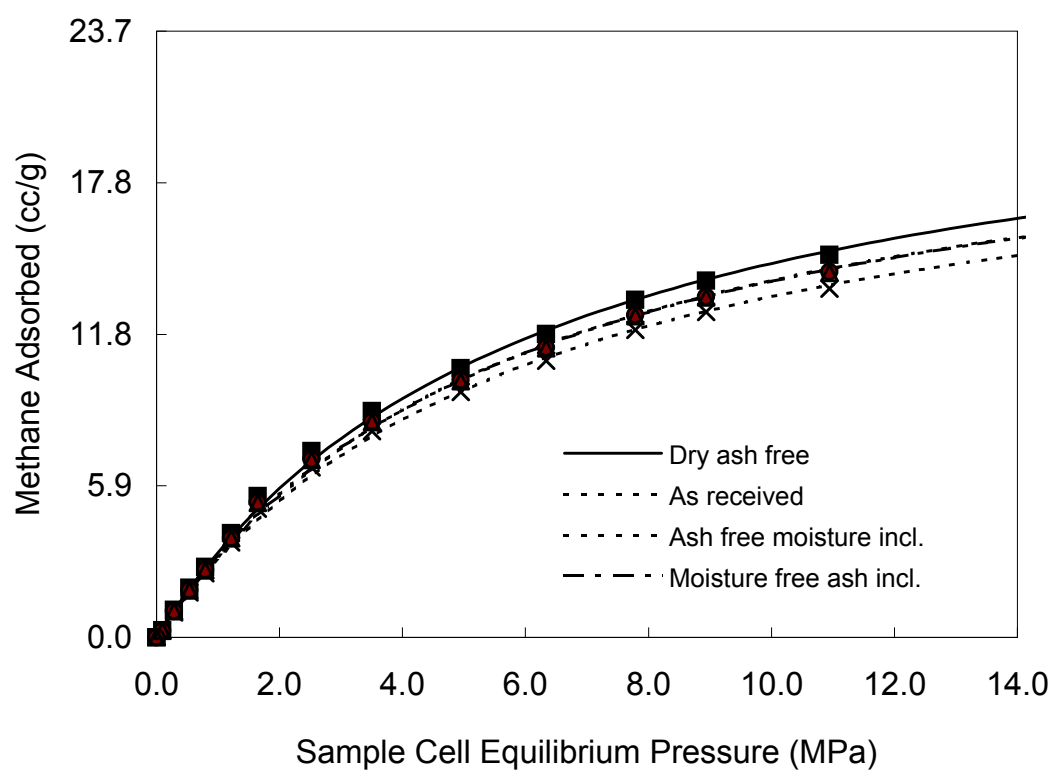

\begin{tabular}{|c|c|c|c|c|}
\hline \multirow{2}{*}{ Pressure } & \multicolumn{4}{|c|}{ Adsorbed gas (cc/g) } \\
\cline { 2 - 5 }$(\mathrm{MPa})$ & $\begin{array}{c}\text { As } \\
\text { Received }\end{array}$ & $\begin{array}{c}\text { Moisture } \\
\text { free ash } \\
\text { incl. }\end{array}$ & $\begin{array}{c}\text { ash free } \\
\text { moisture } \\
\text { incl }\end{array}$ & $\begin{array}{c}\text { Dry Ash } \\
\text { Free }\end{array}$ \\
\hline 0.092 & 0.25 & 0.26 & 0.27 & 0.28 \\
0.283 & 0.98 & 1.02 & 1.02 & 1.07 \\
0.536 & 1.76 & 1.84 & 1.85 & 1.93 \\
0.791 & 2.52 & 2.63 & 2.63 & 2.76 \\
1.215 & 3.71 & 3.88 & 3.88 & 4.07 \\
1.644 & 5.04 & 5.26 & 5.27 & 5.52 \\
2.521 & 6.64 & 6.94 & 6.96 & 7.29 \\
3.502 & 8.06 & 8.42 & 8.44 & 8.84 \\
4.946 & 9.59 & 10.02 & 10.05 & 10.52 \\
6.338 & 10.82 & 11.30 & 11.33 & 11.86 \\
7.785 & 12.02 & 12.57 & 12.59 & 13.19 \\
8.940 & 12.71 & 13.29 & 13.32 & 13.94 \\
10.942 & 13.63 & 14.25 & 14.28 & 14.95 \\
& & & \\
\hline
\end{tabular}

\begin{tabular}{|l|c|c|c|c|} 
& $\begin{array}{c}\text { As } \\
\text { Received }\end{array}$ & $\begin{array}{c}\text { Moisture } \\
\text { free ash } \\
\text { incl. }\end{array}$ & $\begin{array}{c}\text { Ash free } \\
\text { moisture } \\
\text { incl }\end{array}$ & $\begin{array}{c}\text { Dry Ash } \\
\text { Free }\end{array}$ \\
\hline Vol. (cc/g) & 21.40 & 22.36 & 22.41 & 23.47 \\
Pressure (MPa) & 6.05 & 6.05 & 6.05 & 6.05 \\
\hline
\end{tabular}

SUMMARY OF ADSORPTION ANALYSES SI UNITS Isotherm Temperature: Goodness of fit of Langmuir regression: $28.0^{\circ} \mathrm{C}$ 


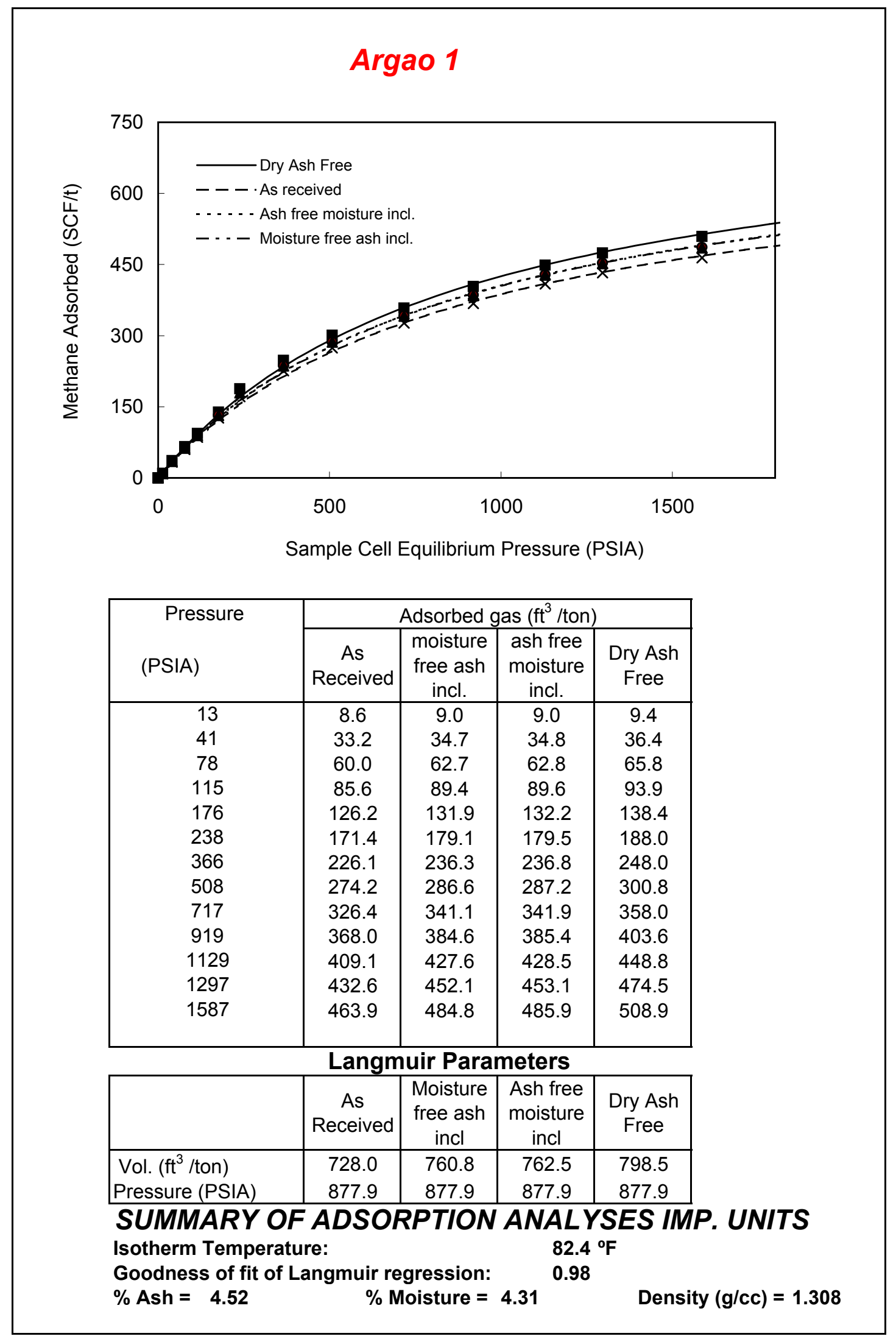




\section{Adsorption Langmuir Plot}

Cebu

Sample Argao 1

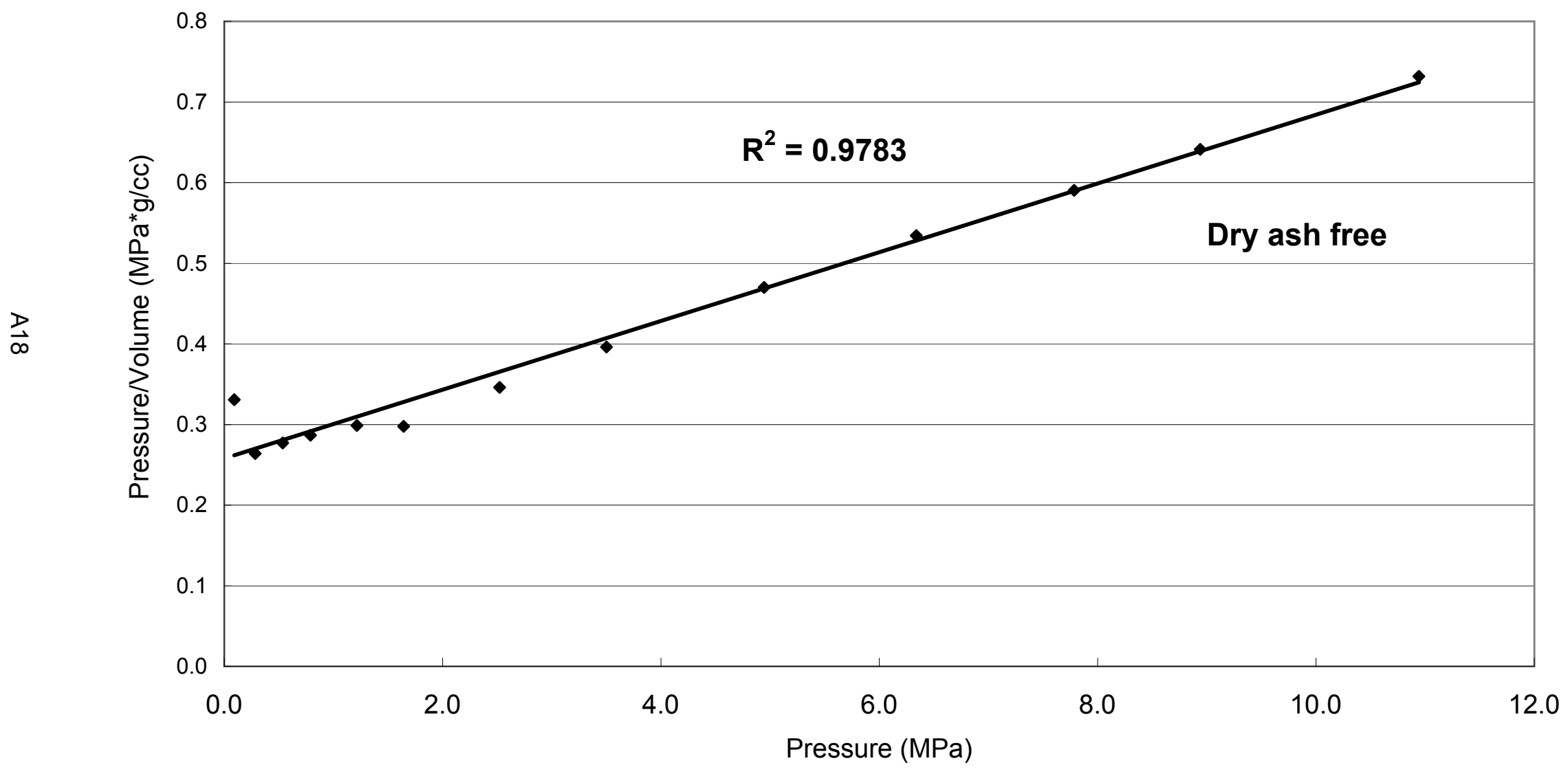




\section{Toledo 1}

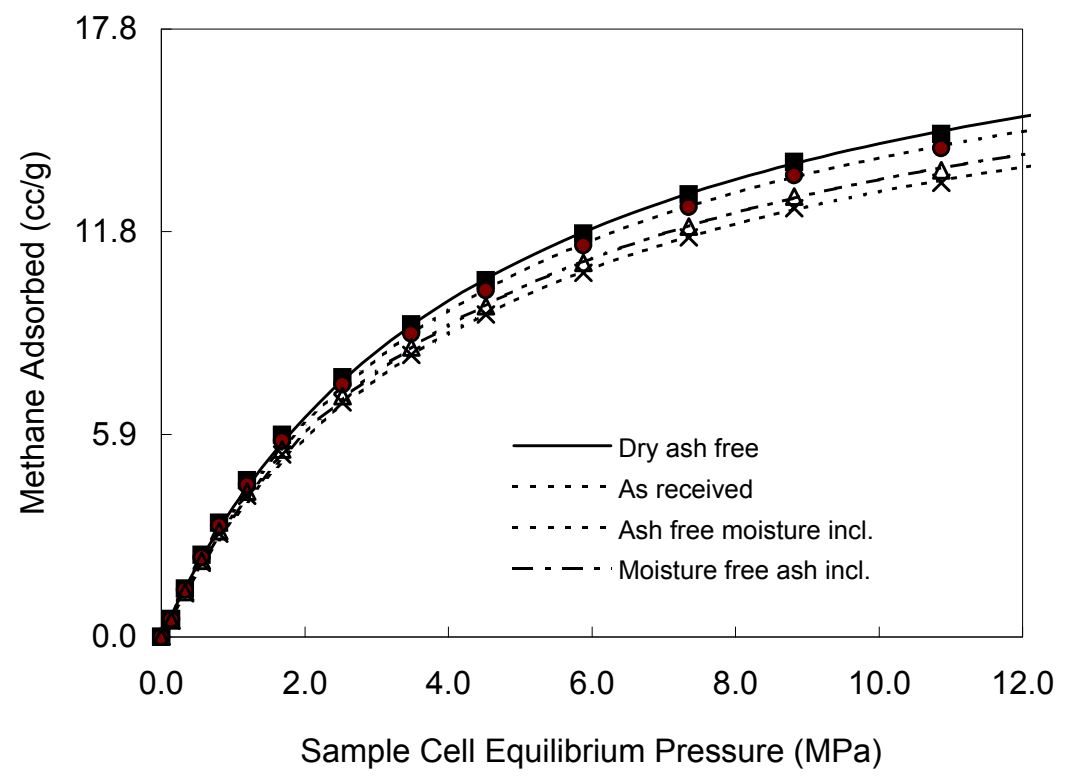

\begin{tabular}{|c|c|c|c|c|}
\hline \multirow{2}{*}{ Pressure } & \multicolumn{4}{|c|}{ Adsorbed gas (cc/g) } \\
\cline { 2 - 5 }$(\mathrm{MPa})$ & $\begin{array}{c}\text { As } \\
\text { Received }\end{array}$ & $\begin{array}{c}\text { Moisture } \\
\text { free ash } \\
\text { incl. }\end{array}$ & $\begin{array}{c}\text { ash free } \\
\text { moisture } \\
\text { incl }\end{array}$ & $\begin{array}{c}\text { Dry Ash } \\
\text { Free }\end{array}$ \\
\hline 0.138 & 0.47 & 0.49 & 0.51 & 0.52 \\
0.332 & 1.28 & 1.31 & 1.38 & 1.42 \\
0.561 & 2.17 & 2.23 & 2.33 & 2.40 \\
0.807 & 3.02 & 3.10 & 3.25 & 3.34 \\
1.194 & 4.13 & 4.25 & 4.45 & 4.58 \\
1.682 & 5.34 & 5.48 & 5.74 & 5.91 \\
2.526 & 6.86 & 7.04 & 7.38 & 7.59 \\
3.484 & 8.25 & 8.47 & 8.87 & 9.13 \\
4.525 & 9.42 & 9.68 & 10.14 & 10.43 \\
5.880 & 10.65 & 10.93 & 11.45 & 11.79 \\
7.349 & 11.68 & 12.00 & 12.57 & 12.93 \\
8.817 & 12.54 & 12.88 & 13.49 & 13.89 \\
10.869 & 13.28 & 13.64 & 14.29 & 14.70 \\
& & & & \\
\hline
\end{tabular}

Langmuir Parameters

\begin{tabular}{|l|c|c|c|c|}
\hline & $\begin{array}{c}\text { As } \\
\text { Received }\end{array}$ & $\begin{array}{c}\text { Moisture } \\
\text { free ash } \\
\text { incl. }\end{array}$ & $\begin{array}{c}\text { Ash free } \\
\text { moisture } \\
\text { incl }\end{array}$ & $\begin{array}{c}\text { Dry Ash } \\
\text { Free }\end{array}$ \\
\hline Vol. (cc/g) & 18.92 & 19.44 & 20.36 & 20.95 \\
Pressure (MPa) & 4.53 & 4.53 & 4.53 & 4.53 \\
\hline
\end{tabular}

SUMMARY OF ADSORPTION ANAL YSES SI UNITS Isotherm Temperature: $\quad 28.0^{\circ} \mathrm{C}$ Goodness of fit of Langmuir regression: $\quad 0.99$ 


\section{Toledo 1}

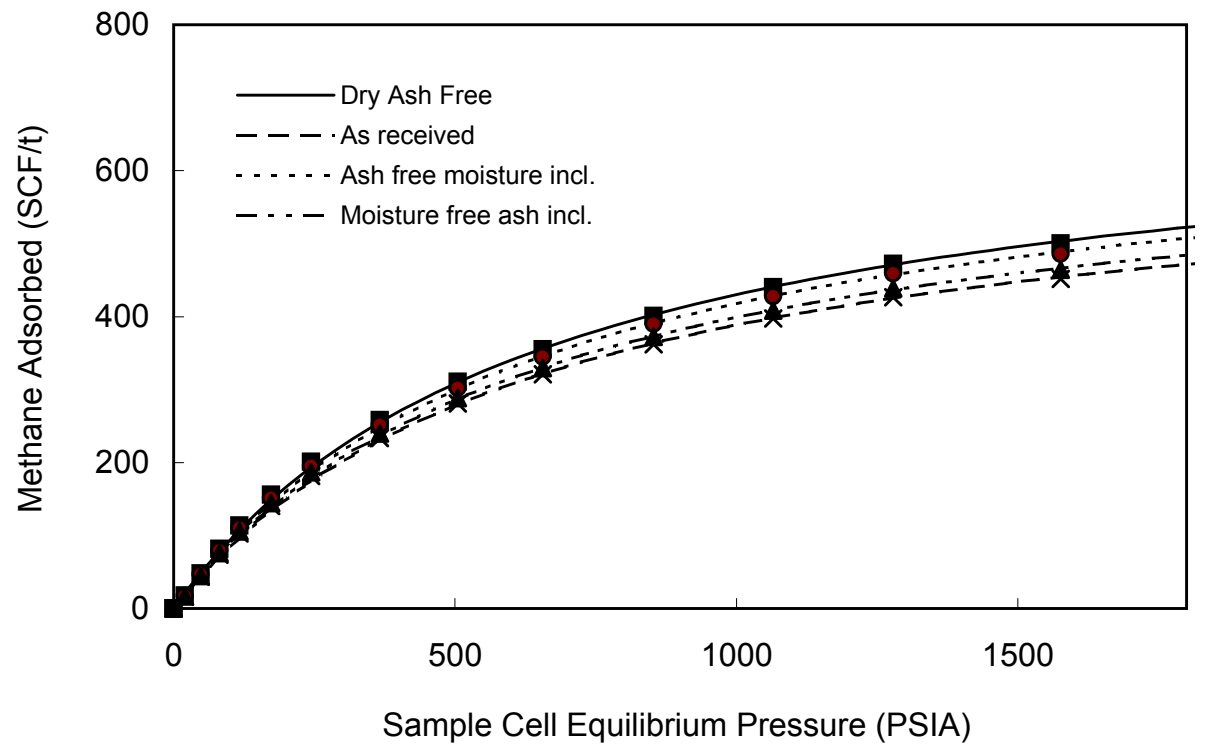

\begin{tabular}{|c|c|c|c|c|}
\hline \multirow{2}{*}{$\begin{array}{l}\text { Pressure } \\
\text { (PSIA) }\end{array}$} & \multicolumn{4}{|c|}{ Adsorbed gas ( $\mathrm{ft}^{3} /$ ton) } \\
\hline & $\begin{array}{c}\text { As } \\
\text { Received }\end{array}$ & $\begin{array}{c}\text { moisture } \\
\text { free ash } \\
\text { incl. }\end{array}$ & $\begin{array}{c}\text { ash free } \\
\text { moisture } \\
\text { incl. }\end{array}$ & $\begin{array}{c}\text { Dry Ash } \\
\text { Free }\end{array}$ \\
\hline 20 & 16.1 & 16.5 & 17.3 & 17.8 \\
\hline 48 & 43.5 & 44.7 & 46.8 & 48.2 \\
\hline 81 & 73.7 & 75.7 & 79.3 & 81.6 \\
\hline 117 & 102.7 & 105.5 & 110.5 & 113.7 \\
\hline 173 & 140.7 & 144.5 & 151.4 & 155.8 \\
\hline 244 & 181.6 & 186.5 & 195.4 & 201.0 \\
\hline 366 & 233.4 & 239.7 & 251.1 & 258.4 \\
\hline 505 & 280.7 & 288.3 & 302.0 & 310.8 \\
\hline 656 & 320.7 & 329.3 & 345.0 & 355.1 \\
\hline 853 & 362.3 & 372.1 & 389.8 & 401.1 \\
\hline 1066 & 397.5 & 408.2 & 427.7 & 440.1 \\
\hline 1279 & 426.8 & 438.3 & 459.1 & 472.5 \\
\hline 1576 & 451.9 & 464.1 & 486.2 & 500.4 \\
\hline \multicolumn{5}{|c|}{ Langmuir Parameters } \\
\hline & $\begin{array}{c}\text { As } \\
\text { Received }\end{array}$ & $\begin{array}{c}\text { Moisture } \\
\text { free ash } \\
\text { incl }\end{array}$ & $\begin{array}{c}\text { Ash free } \\
\text { moisture } \\
\text { incl }\end{array}$ & $\begin{array}{c}\text { Dry Ash } \\
\text { Free }\end{array}$ \\
\hline Vol. (ft ${ }^{3} /$ ton) & 644.0 & 661.3 & 692.8 & 712.9 \\
\hline Pressure (PSIA) & 656.9 & 656.9 & 656.9 & 656.9 \\
\hline
\end{tabular}

SUMMARY OF ADSORPTION ANALYSES IMP. UNITS Isotherm Temperature: $82.4^{\circ} \mathrm{F}$ Goodness of fit of Langmuir regression: $\quad 0.99$ 


\section{Adsorption Langmuir Plot}

Cebu

Sample Toledo 1

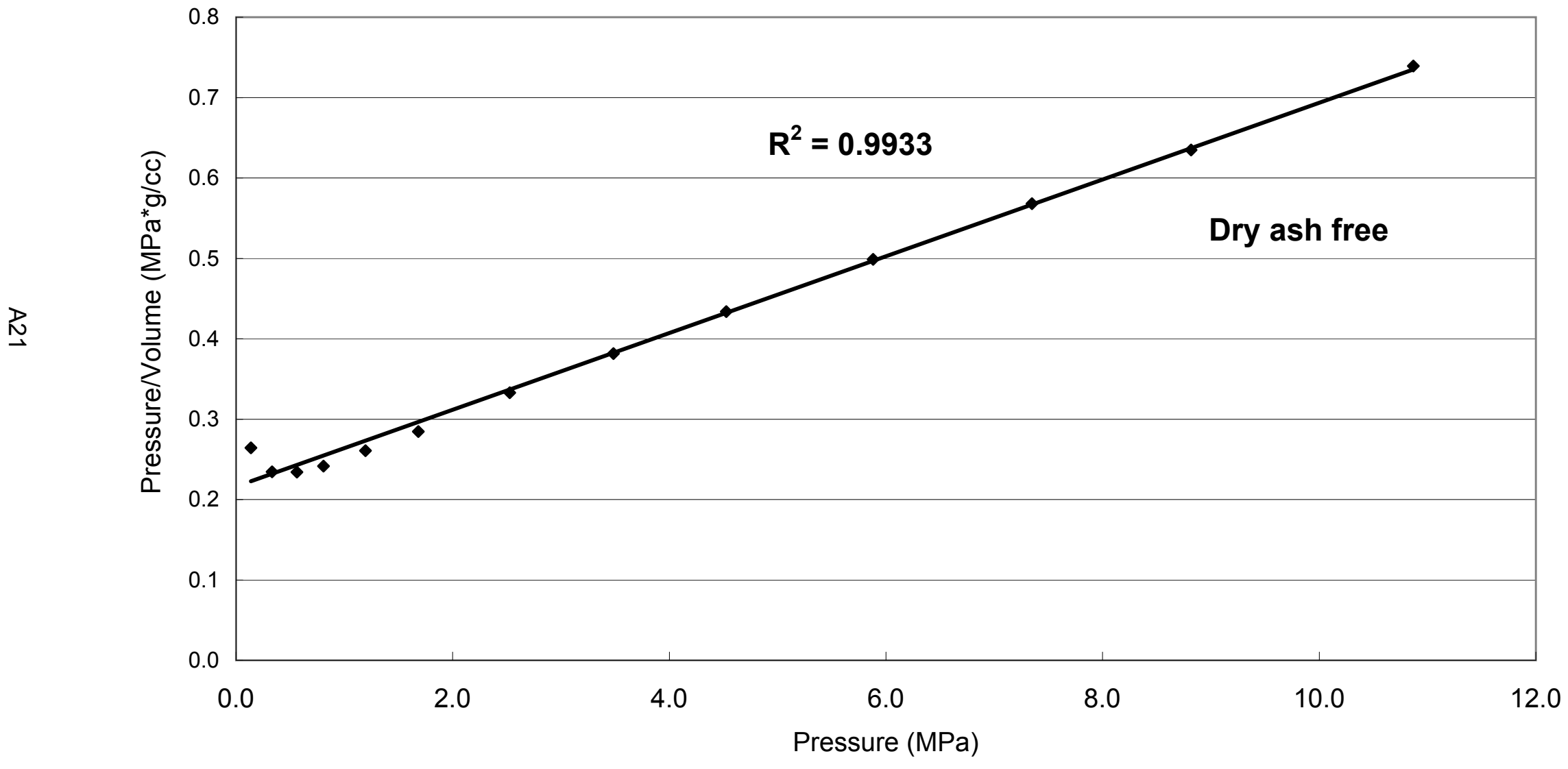




\section{Dalaguete 1}

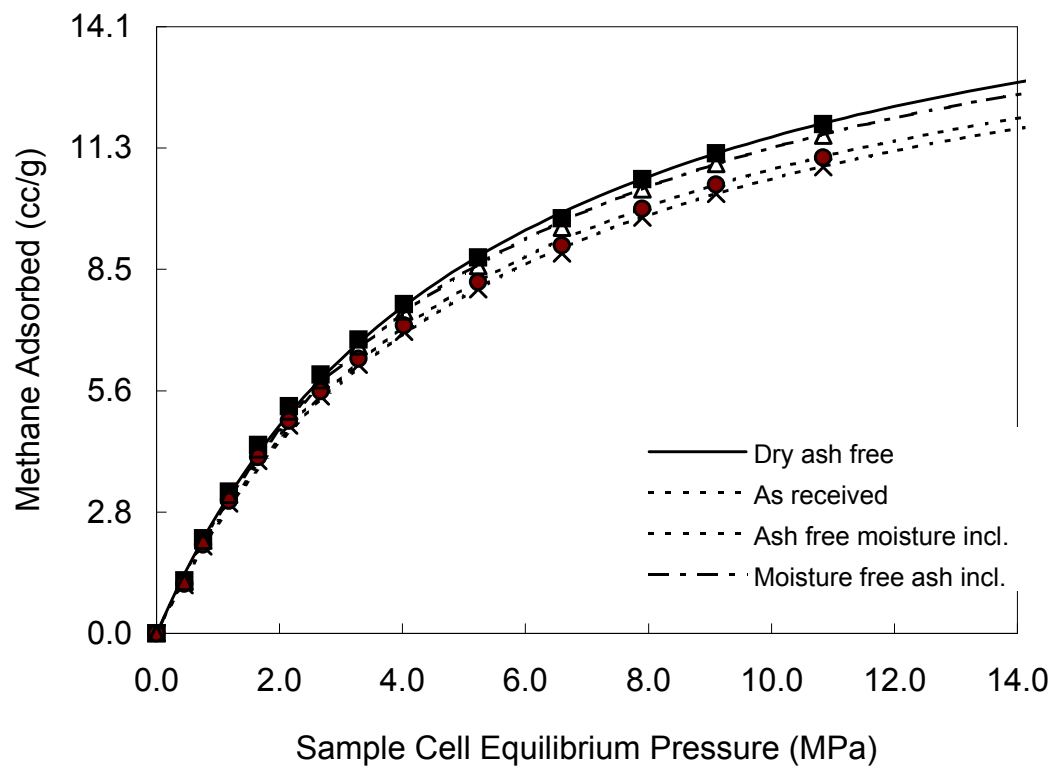

\begin{tabular}{|c|c|c|c|c|}
\hline \multirow{2}{*}{ Pressure } & \multicolumn{4}{|c|}{ Adsorbed gas (cc/g) } \\
\cline { 2 - 5 } & $\begin{array}{c}\text { As } \\
\text { Received }\end{array}$ & $\begin{array}{c}\text { Moisture } \\
\text { free ash } \\
\text { incl. }\end{array}$ & $\begin{array}{c}\text { ash free } \\
\text { moisture } \\
\text { incl }\end{array}$ & $\begin{array}{c}\text { Dry Ash } \\
\text { Free }\end{array}$ \\
\hline 0.455 & 1.13 & 1.20 & 1.15 & 1.23 \\
0.760 & 2.02 & 2.16 & 2.07 & 2.21 \\
1.180 & 3.02 & 3.22 & 3.08 & 3.30 \\
1.651 & 4.01 & 4.28 & 4.09 & 4.38 \\
2.158 & 4.84 & 5.16 & 4.94 & 5.28 \\
2.668 & 5.51 & 5.89 & 5.63 & 6.02 \\
3.289 & 6.25 & 6.68 & 6.38 & 6.82 \\
4.023 & 7.01 & 7.48 & 7.15 & 7.65 \\
5.228 & 8.00 & 8.54 & 8.16 & 8.73 \\
6.591 & 8.83 & 9.44 & 9.02 & 9.64 \\
7.900 & 9.66 & 10.32 & 9.86 & 10.55 \\
9.100 & 10.22 & 10.92 & 10.43 & 11.16 \\
10.840 & 10.83 & 11.57 & 11.06 & 11.83 \\
& & & \\
\hline
\end{tabular}

\begin{tabular}{|l|c|c|c|c|}
\hline & $\begin{array}{c}\text { As } \\
\text { Received }\end{array}$ & $\begin{array}{c}\text { Moisture } \\
\text { free ash } \\
\text { incl. }\end{array}$ & $\begin{array}{c}\text { Ash free } \\
\text { moisture } \\
\text { incl }\end{array}$ & $\begin{array}{c}\text { Dry Ash } \\
\text { Free }\end{array}$ \\
\hline Vol. (cc/g) & 16.19 & 17.29 & 16.52 & 17.67 \\
Pressure (MPa) & 5.32 & 5.32 & 5.32 & 5.32 \\
\hline
\end{tabular}

SUMMARY OF ADSORPTION ANALYSES SI UNITS Isotherm Temperature: Goodness of fit of Langmuir regression: $28.0^{\circ} \mathrm{C}$ $\%$ Ash $=2.03$ $\%$ Moisture $=6.37$ Density $(g / c c)=1.300$ 


\section{Dalaguete 1}

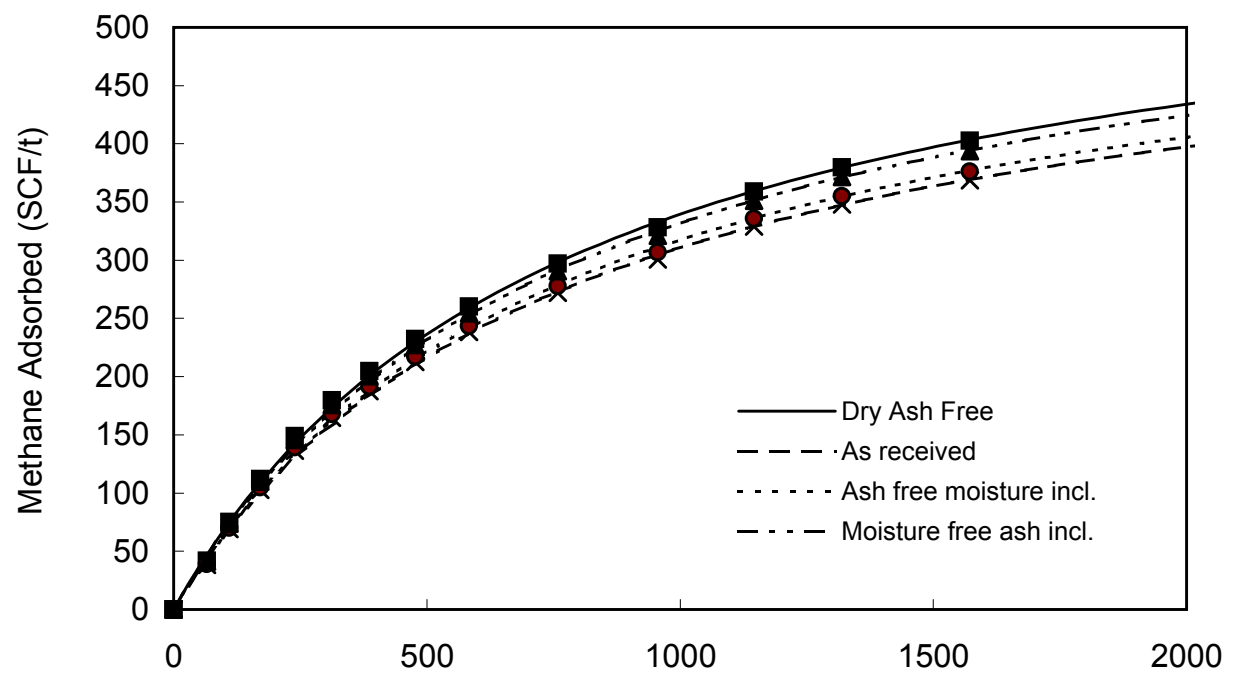

Sample Cell Equilibrium Pressure (PSIA)

\begin{tabular}{|c|c|c|c|c|}
\hline \multirow{2}{*}{$\begin{array}{l}\text { Pressure } \\
\text { (PSIA) }\end{array}$} & \multicolumn{4}{|c|}{ Adsorbed gas ( $\mathrm{ft}^{3} /$ ton) } \\
\hline & $\begin{array}{c}\text { As } \\
\text { Received }\end{array}$ & $\begin{array}{c}\text { moisture } \\
\text { free ash } \\
\text { incl. }\end{array}$ & $\begin{array}{c}\text { ash free } \\
\text { moisture } \\
\text { incl. }\end{array}$ & $\begin{array}{c}\text { Dry Ash } \\
\text { Free }\end{array}$ \\
\hline 66 & 38.4 & 41.0 & 39.2 & 41.9 \\
\hline 110 & 68.9 & 73.6 & 70.3 & 75.2 \\
\hline 171 & 102.7 & 109.7 & 104.8 & 112.1 \\
\hline 239 & 136.4 & 145.7 & 139.2 & 148.9 \\
\hline 313 & 164.5 & 175.7 & 167.9 & 179.6 \\
\hline 387 & 187.5 & 200.3 & 191.4 & 204.7 \\
\hline 477 & 212.7 & 227.1 & 217.1 & 232.2 \\
\hline 584 & 238.4 & 254.6 & 243.4 & 260.3 \\
\hline 758 & 272.1 & 290.7 & 277.8 & 297.1 \\
\hline 956 & 300.6 & 321.0 & 306.8 & 328.2 \\
\hline 1146 & 328.8 & 351.2 & 335.7 & 359.0 \\
\hline 1320 & 347.8 & 371.4 & 355.0 & 379.7 \\
\hline 1572 & 368.7 & 393.8 & 376.3 & 402.5 \\
\hline \multicolumn{5}{|c|}{ Langmuir Parameters } \\
\hline & $\begin{array}{c}\text { As } \\
\text { Received }\end{array}$ & $\begin{array}{c}\text { Moisture } \\
\text { free ash } \\
\text { incl }\end{array}$ & $\begin{array}{c}\text { Ash free } \\
\text { moisture } \\
\text { incl }\end{array}$ & $\begin{array}{c}\text { Dry Ash } \\
\text { Free }\end{array}$ \\
\hline Vol. (ft ${ }^{3} /$ ton) & 550.8 & 588.3 & 562.2 & 601.3 \\
\hline Pressure (PSIA) & 771.2 & 771.2 & 771.2 & 771.2 \\
\hline
\end{tabular}

SUMMARY OF ADSORPTION ANALYSES IMP. UNITS Isotherm Temperature: $82.4^{\circ} \mathrm{F}$ Goodness of fit of Langmuir regression: $\quad 0.99$ 


\section{Adsorption Langmuir Plot}

\section{Cebu}

Sample Dalaguete 1

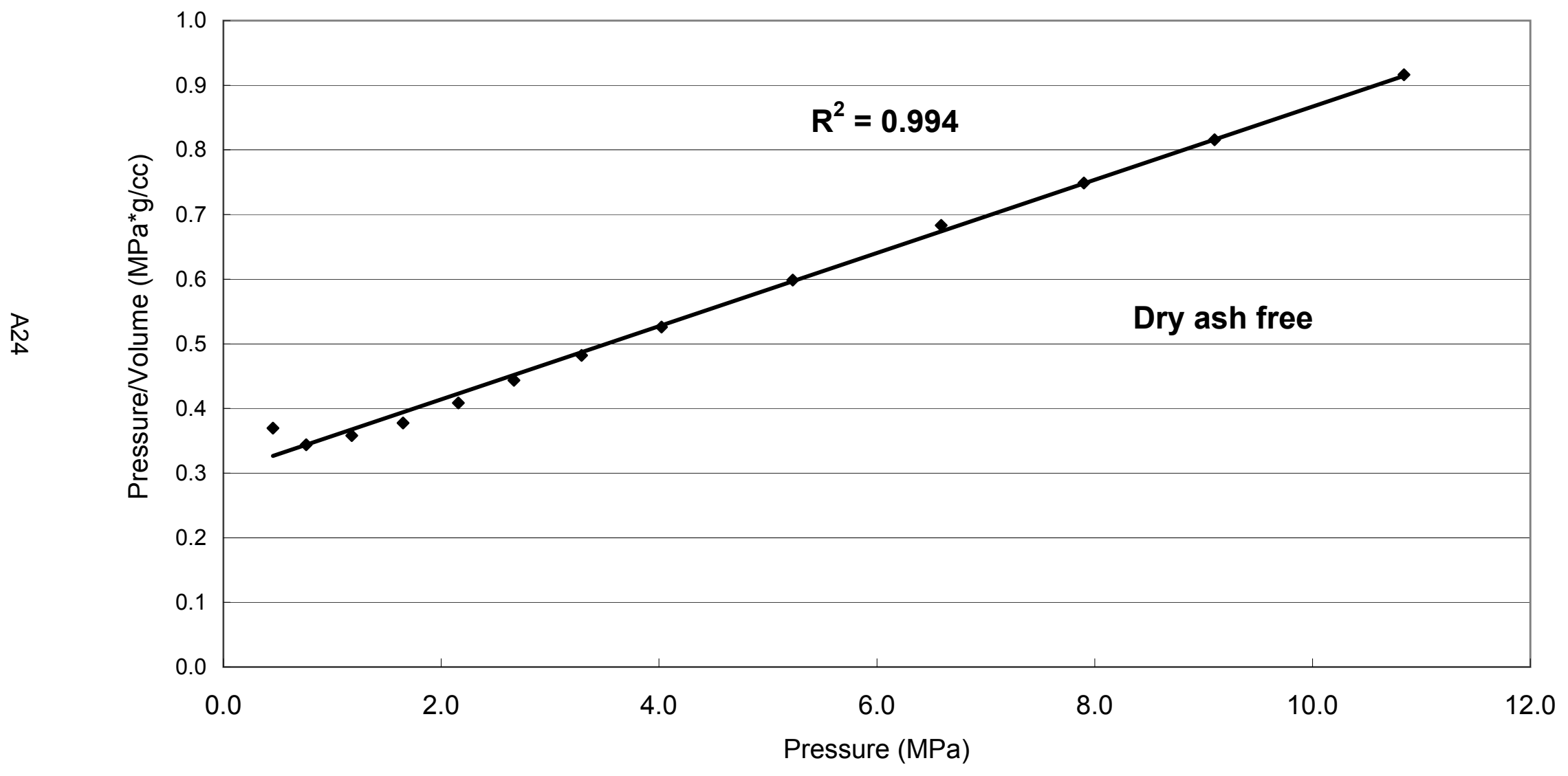




\section{Isabella 1}

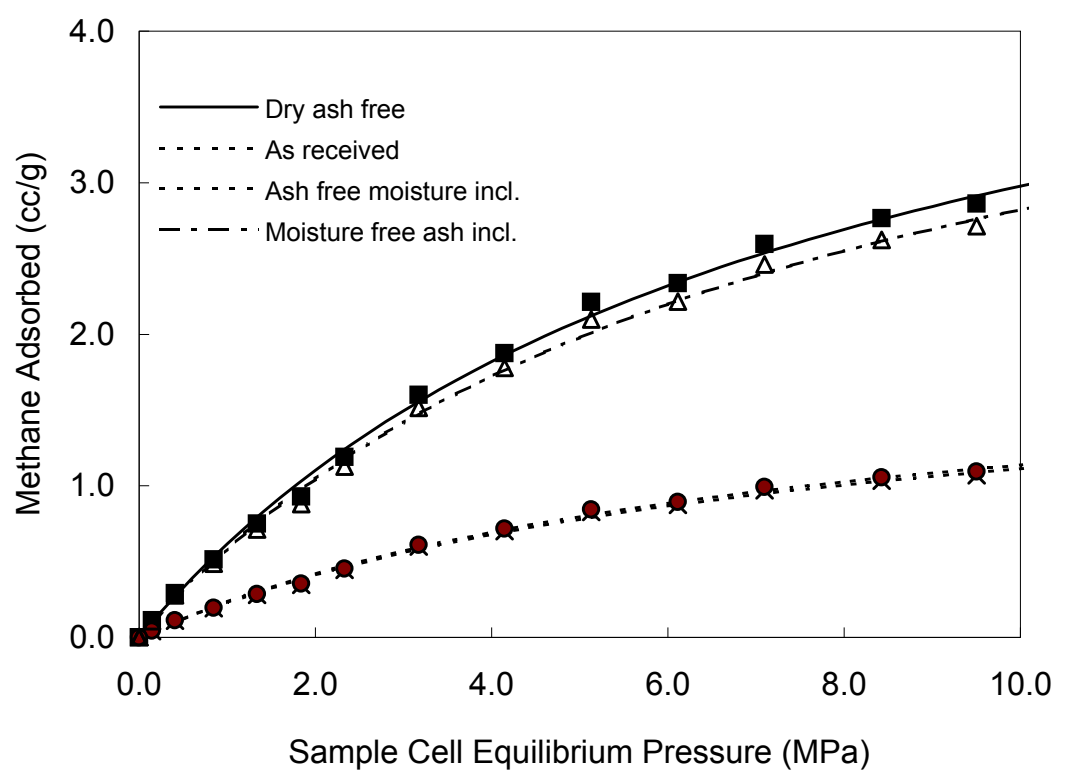

\begin{tabular}{|c|c|c|c|c|}
\hline \multirow{2}{*}{ Pressure } & \multicolumn{4}{|c|}{ Adsorbed gas (cc/g) } \\
\cline { 2 - 5 }$(\mathrm{MPa})$ & $\begin{array}{c}\text { As } \\
\text { Received }\end{array}$ & $\begin{array}{c}\text { Moisture } \\
\text { free ash } \\
\text { incl. }\end{array}$ & $\begin{array}{c}\text { ash free } \\
\text { moisture } \\
\text { incl }\end{array}$ & $\begin{array}{c}\text { Dry Ash } \\
\text { Free }\end{array}$ \\
\hline 0.148 & 0.04 & 0.11 & 0.04 & 0.11 \\
0.408 & 0.11 & 0.28 & 0.11 & 0.29 \\
0.845 & 0.19 & 0.49 & 0.20 & 0.51 \\
1.338 & 0.28 & 0.71 & 0.29 & 0.75 \\
1.838 & 0.35 & 0.88 & 0.36 & 0.93 \\
2.332 & 0.45 & 1.13 & 0.45 & 1.19 \\
3.174 & 0.60 & 1.52 & 0.61 & 1.60 \\
4.148 & 0.70 & 1.78 & 0.72 & 1.88 \\
5.129 & 0.83 & 2.10 & 0.85 & 2.21 \\
6.116 & 0.87 & 2.22 & 0.89 & 2.34 \\
7.095 & 0.97 & 2.46 & 0.99 & 2.60 \\
8.426 & 1.03 & 2.62 & 1.06 & 2.77 \\
9.506 & 1.07 & 2.71 & 1.09 & 2.86 \\
& & & & \\
\hline
\end{tabular}

\begin{tabular}{|l|c|c|c|c|}
\hline & $\begin{array}{c}\text { As } \\
\text { Received }\end{array}$ & $\begin{array}{c}\text { Moisture } \\
\text { free ash } \\
\text { incl. }\end{array}$ & $\begin{array}{c}\text { Ash free } \\
\text { moisture } \\
\text { incl }\end{array}$ & $\begin{array}{c}\text { Dry Ash } \\
\text { Free }\end{array}$ \\
\hline Vol. (cc/g) & 1.94 & 4.90 & 1.98 & 5.17 \\
Pressure (MPa) & 7.38 & 7.38 & 7.38 & 7.38 \\
\hline
\end{tabular}

SUMMARY OF ADSORPTION ANALYSES SI UNITS Isotherm Temperature: $\quad 28.0^{\circ} \mathrm{C}$ Goodness of fit of Langmuir regression: $\quad 0.97$ 


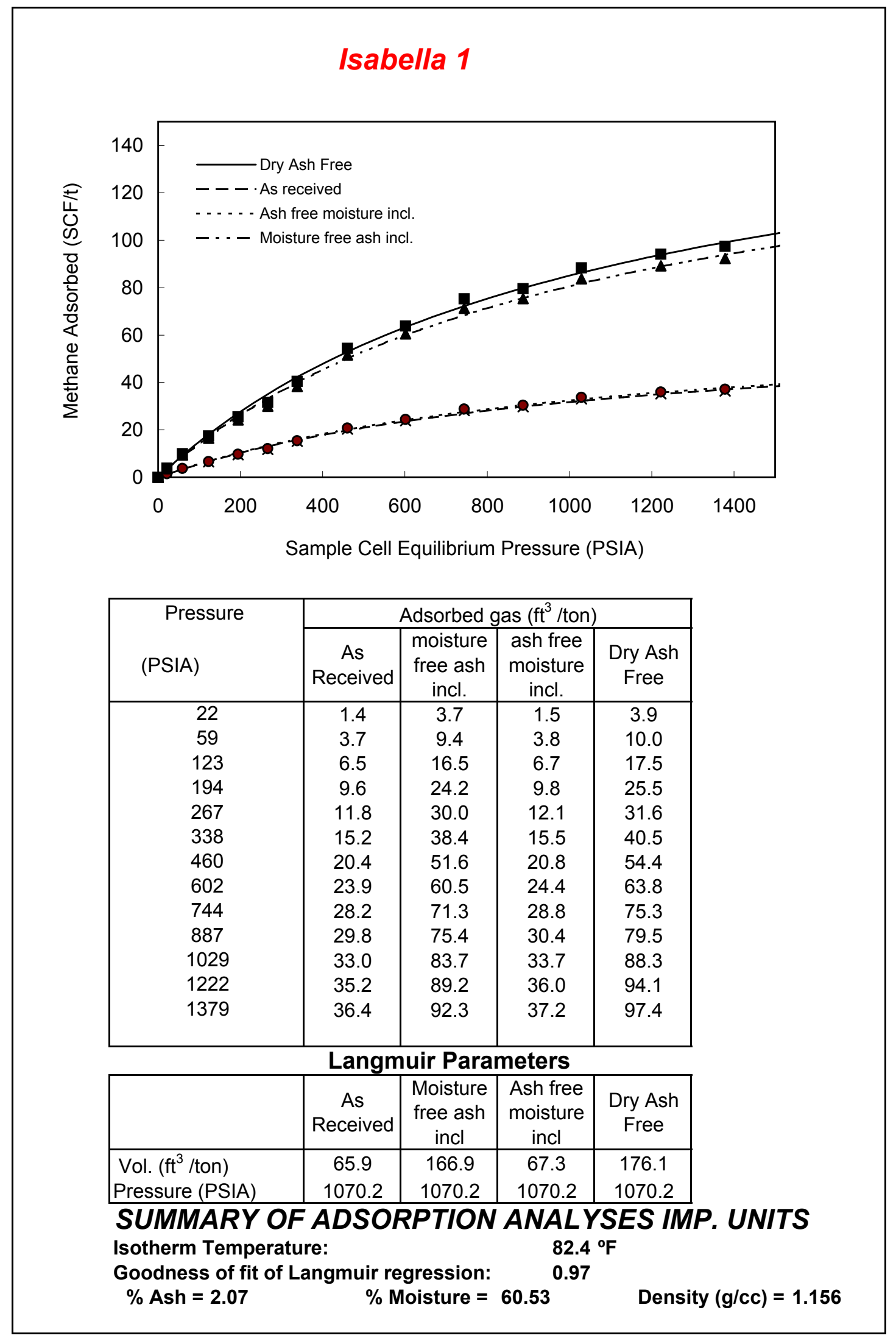


Adsorption Langmuir Plot

Cayayan-Isabella

Sample Isabella 1

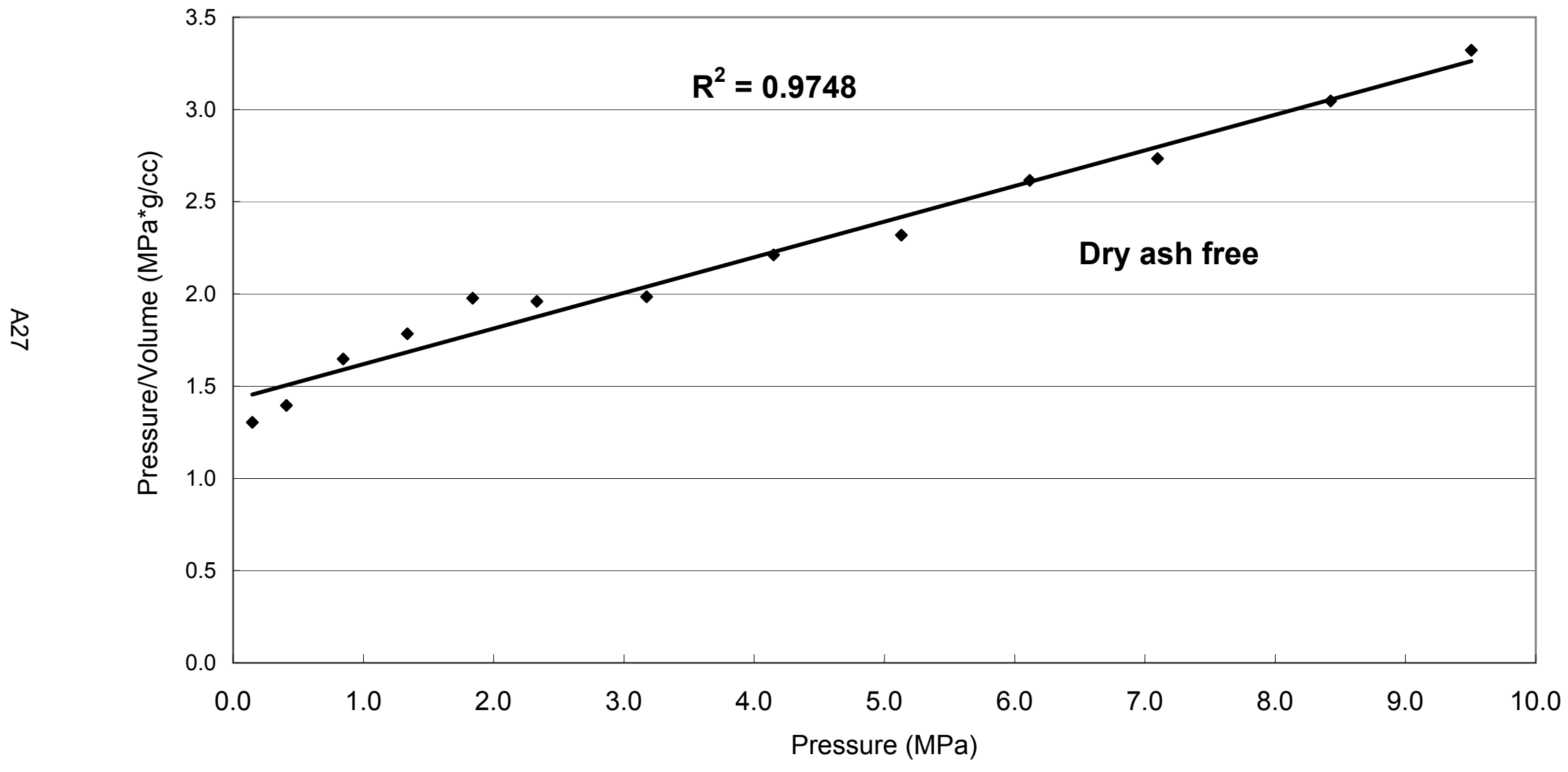




\section{Calatrava 1}

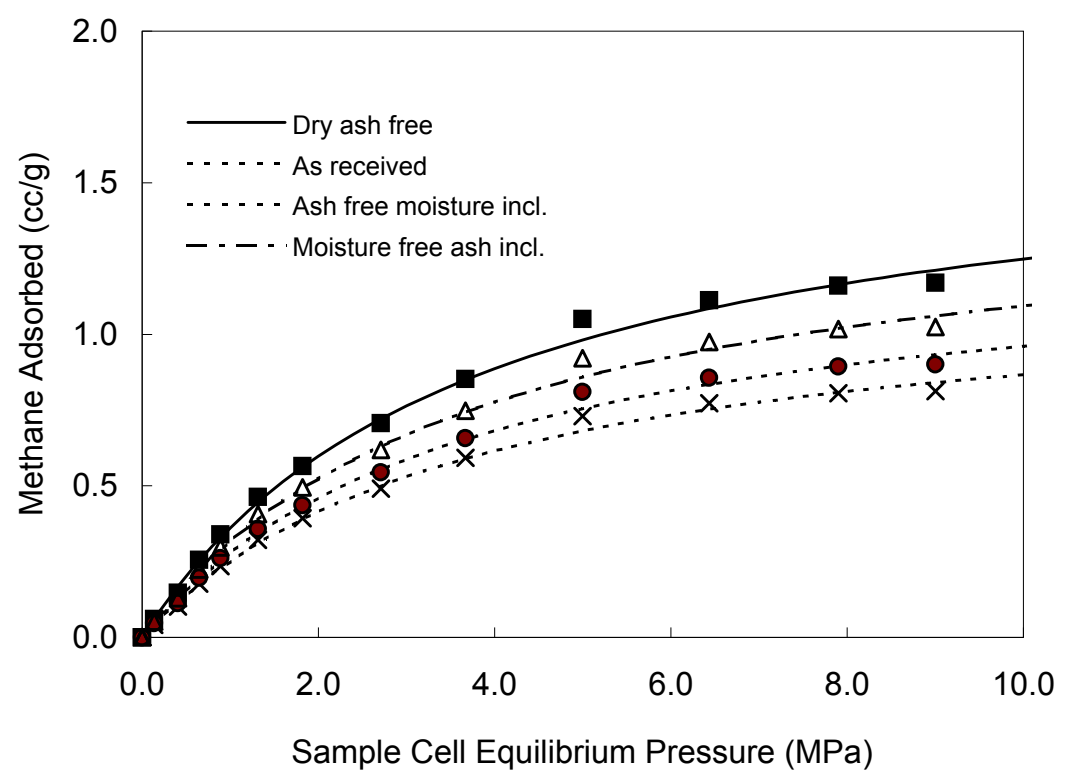

\begin{tabular}{|c|c|c|c|c|}
\hline \multirow{2}{*}{ Pressure } & \multicolumn{4}{|c|}{ Adsorbed gas (cc/g) } \\
\cline { 2 - 5 }$(\mathrm{MPa})$ & $\begin{array}{c}\text { As } \\
\text { Received }\end{array}$ & $\begin{array}{c}\text { Moisture } \\
\text { free ash } \\
\text { incl. }\end{array}$ & $\begin{array}{c}\text { ash free } \\
\text { moisture } \\
\text { incl }\end{array}$ & $\begin{array}{c}\text { Dry Ash } \\
\text { Free }\end{array}$ \\
\hline 0.136 & 0.04 & 0.05 & 0.05 & 0.06 \\
0.407 & 0.10 & 0.13 & 0.11 & 0.15 \\
0.649 & 0.18 & 0.22 & 0.20 & 0.26 \\
0.890 & 0.24 & 0.30 & 0.26 & 0.34 \\
1.316 & 0.32 & 0.41 & 0.36 & 0.46 \\
1.820 & 0.39 & 0.50 & 0.44 & 0.57 \\
2.707 & 0.49 & 0.62 & 0.54 & 0.71 \\
3.669 & 0.59 & 0.75 & 0.66 & 0.85 \\
4.997 & 0.73 & 0.92 & 0.81 & 1.05 \\
6.436 & 0.77 & 0.97 & 0.86 & 1.11 \\
7.900 & 0.81 & 1.02 & 0.89 & 1.16 \\
9.002 & 0.81 & 1.02 & 0.90 & 1.17 \\
& & & & \\
& & & & \\
\hline
\end{tabular}

Langmuir Parameters

\begin{tabular}{|l|c|c|c|c|}
\hline & $\begin{array}{c}\text { As } \\
\text { Received }\end{array}$ & $\begin{array}{c}\text { Moisture } \\
\text { free ash } \\
\text { incl. }\end{array}$ & $\begin{array}{c}\text { Ash free } \\
\text { moisture } \\
\text { incl }\end{array}$ & $\begin{array}{c}\text { Dry Ash } \\
\text { Free }\end{array}$ \\
\hline Vol. (cc/g) & 1.19 & 1.50 & 1.32 & 1.71 \\
Pressure (MPa) & 3.74 & 3.74 & 3.74 & 3.74 \\
\hline
\end{tabular}

SUMMARY OF ADSORPTION ANAL YSES SI UNITS Isotherm Temperature: $\quad 28.0^{\circ} \mathrm{C}$ Goodness of fit of Langmuir regression: $\quad 0.99$ 


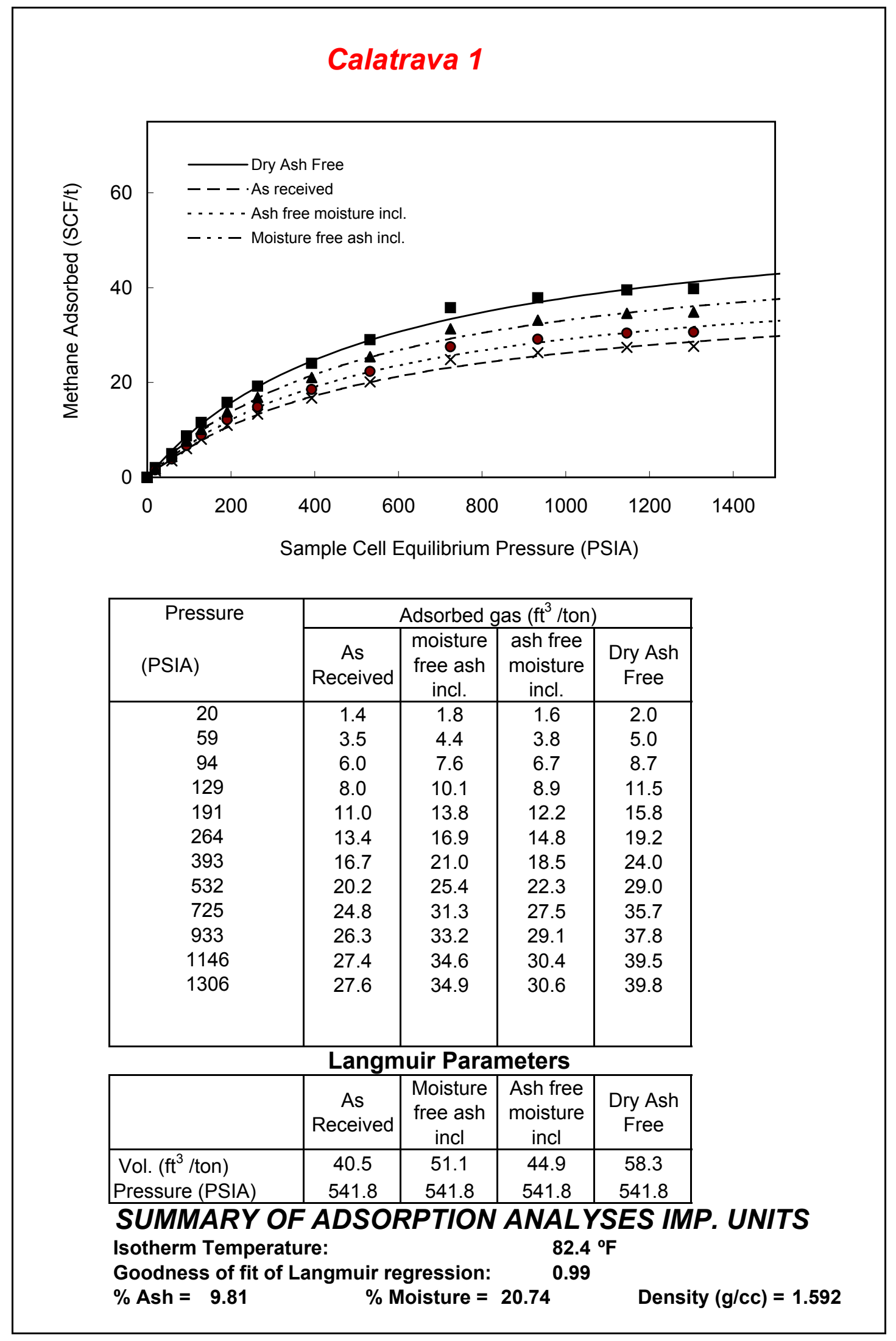




\section{Adsorption Langmuir Plot}

Negros

Sample Calatrava 1

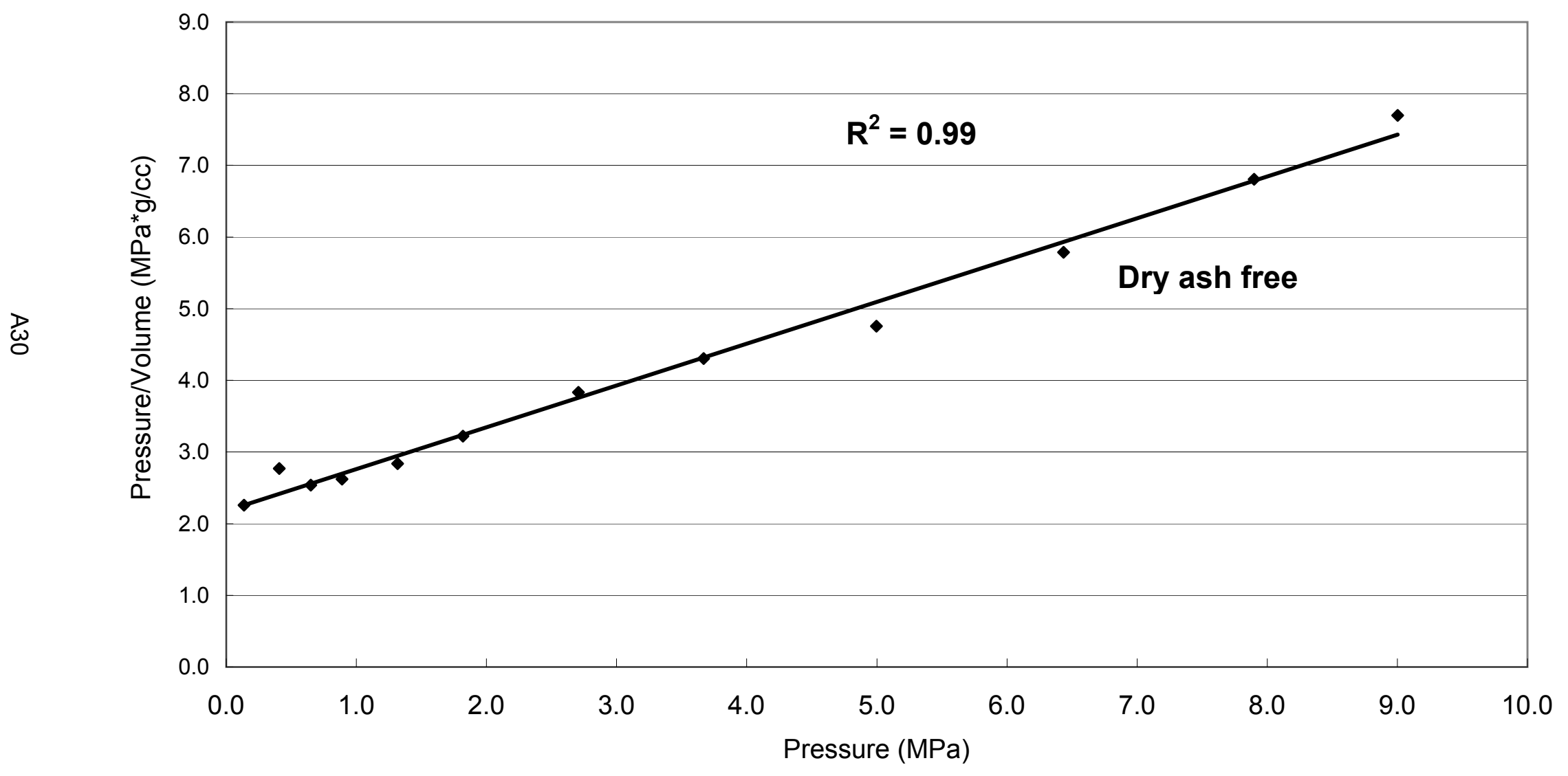




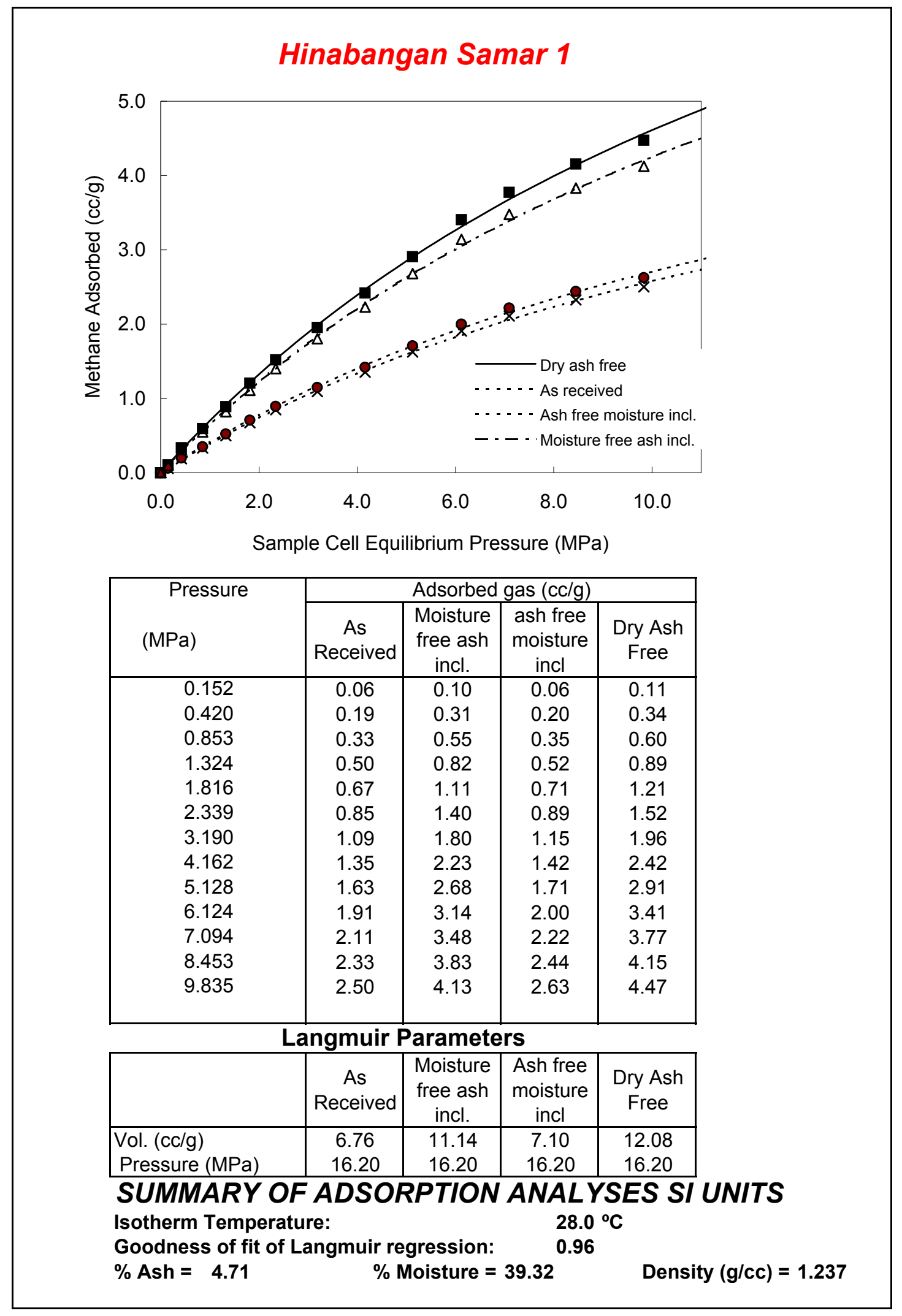




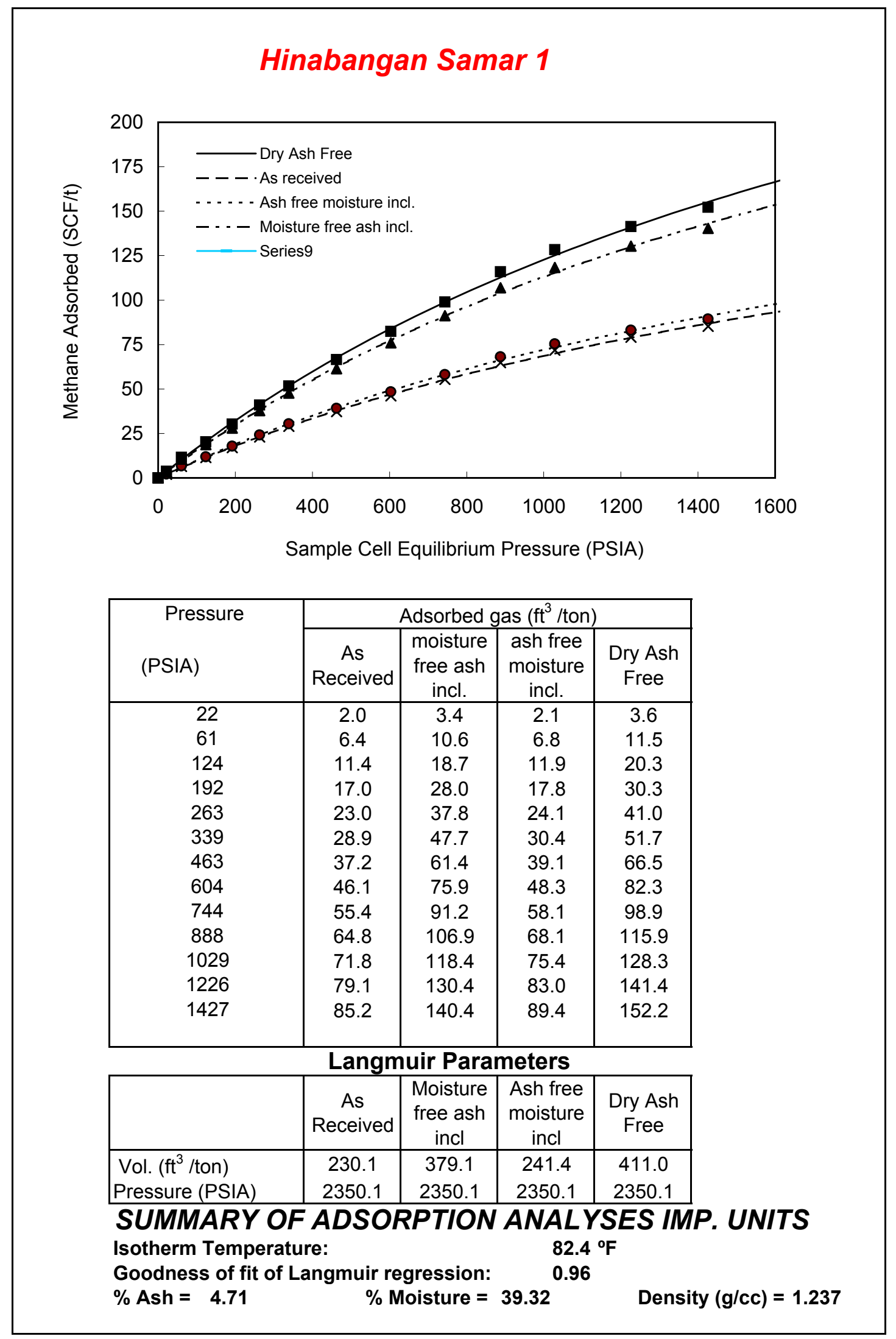


Adsorption Langmuir Plot

Samar

Sample Hinabangan 1

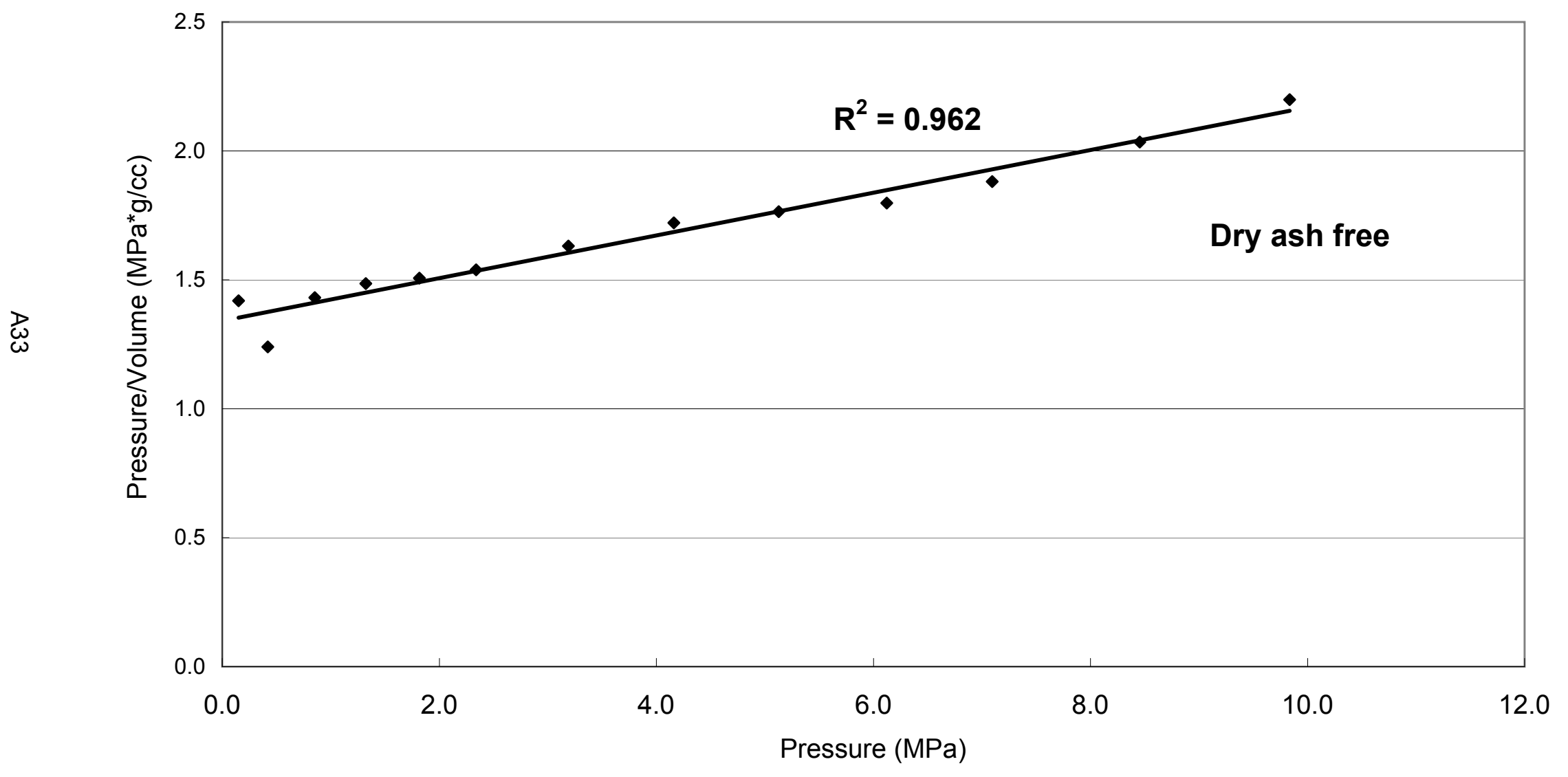




\section{South Cotabato 1}

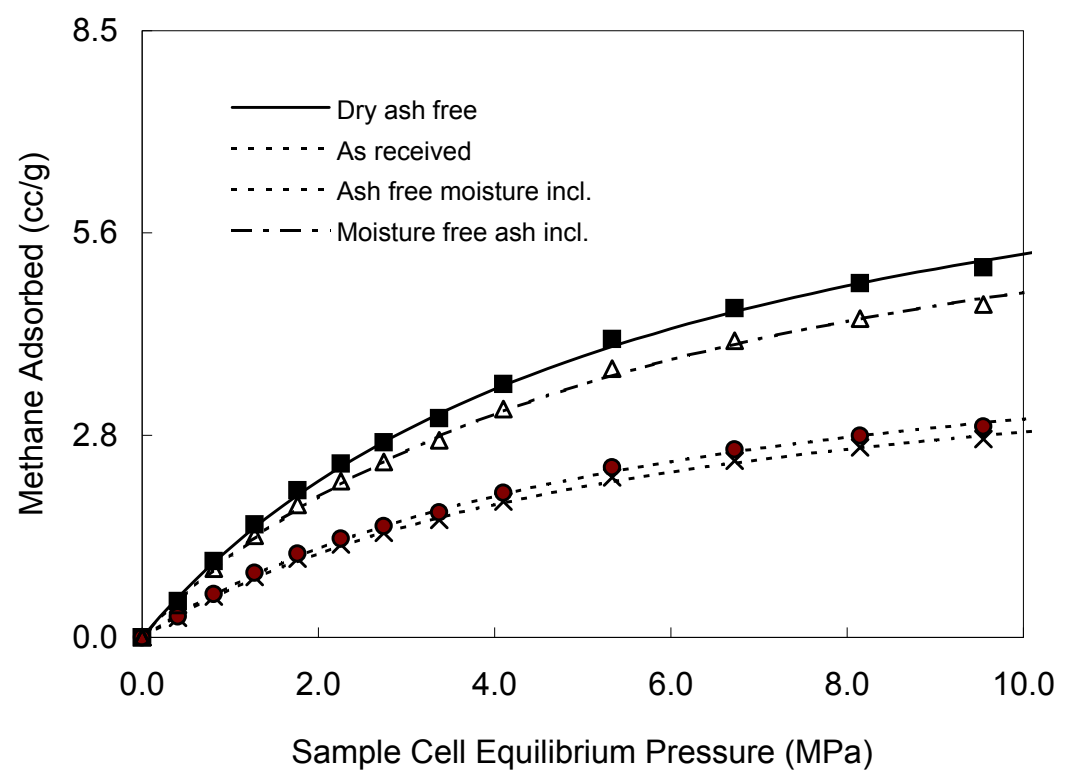

\begin{tabular}{|c|c|c|c|c|}
\hline \multirow{2}{*}{ Pressure } & \multicolumn{4}{|c|}{ Adsorbed gas (cc/g) } \\
\cline { 2 - 5 }$(\mathrm{MPa})$ & $\begin{array}{c}\text { As } \\
\text { Received }\end{array}$ & $\begin{array}{c}\text { Moisture } \\
\text { free ash } \\
\text { incl. }\end{array}$ & $\begin{array}{c}\text { ash free } \\
\text { moisture } \\
\text { incl }\end{array}$ & $\begin{array}{c}\text { Dry Ash } \\
\text { Free }\end{array}$ \\
\hline 0.407 & 0.27 & 0.45 & 0.29 & 0.50 \\
0.811 & 0.57 & 0.96 & 0.61 & 1.06 \\
1.275 & 0.84 & 1.42 & 0.90 & 1.58 \\
1.763 & 1.10 & 1.85 & 1.17 & 2.05 \\
2.256 & 1.30 & 2.18 & 1.38 & 2.42 \\
2.744 & 1.46 & 2.45 & 1.55 & 2.72 \\
3.373 & 1.64 & 2.75 & 1.74 & 3.05 \\
4.101 & 1.89 & 3.18 & 2.01 & 3.53 \\
5.331 & 2.23 & 3.75 & 2.37 & 4.16 \\
6.724 & 2.46 & 4.13 & 2.62 & 4.59 \\
8.145 & 2.65 & 4.44 & 2.81 & 4.94 \\
9.545 & 2.76 & 4.64 & 2.94 & 5.16 \\
& & & & \\
\hline
\end{tabular}

Langmuir Parameters

\begin{tabular}{|l|c|c|c|c|}
\hline & $\begin{array}{c}\text { As } \\
\text { Received }\end{array}$ & $\begin{array}{c}\text { Moisture } \\
\text { free ash } \\
\text { incl. }\end{array}$ & $\begin{array}{c}\text { Ash free } \\
\text { moisture } \\
\text { incl }\end{array}$ & $\begin{array}{c}\text { Dry Ash } \\
\text { Free }\end{array}$ \\
\hline Vol. (cc/g) & 4.50 & 7.56 & 4.79 & 8.40 \\
Pressure (MPa) & 5.71 & 5.71 & 5.71 & 5.71 \\
\hline
\end{tabular}

SUMMARY OF ADSORPTION ANALYSES SI UNITS Isotherm Temperature: $\quad 28.0^{\circ} \mathrm{C}$ Goodness of fit of Langmuir regression: $\quad 0.99$ 


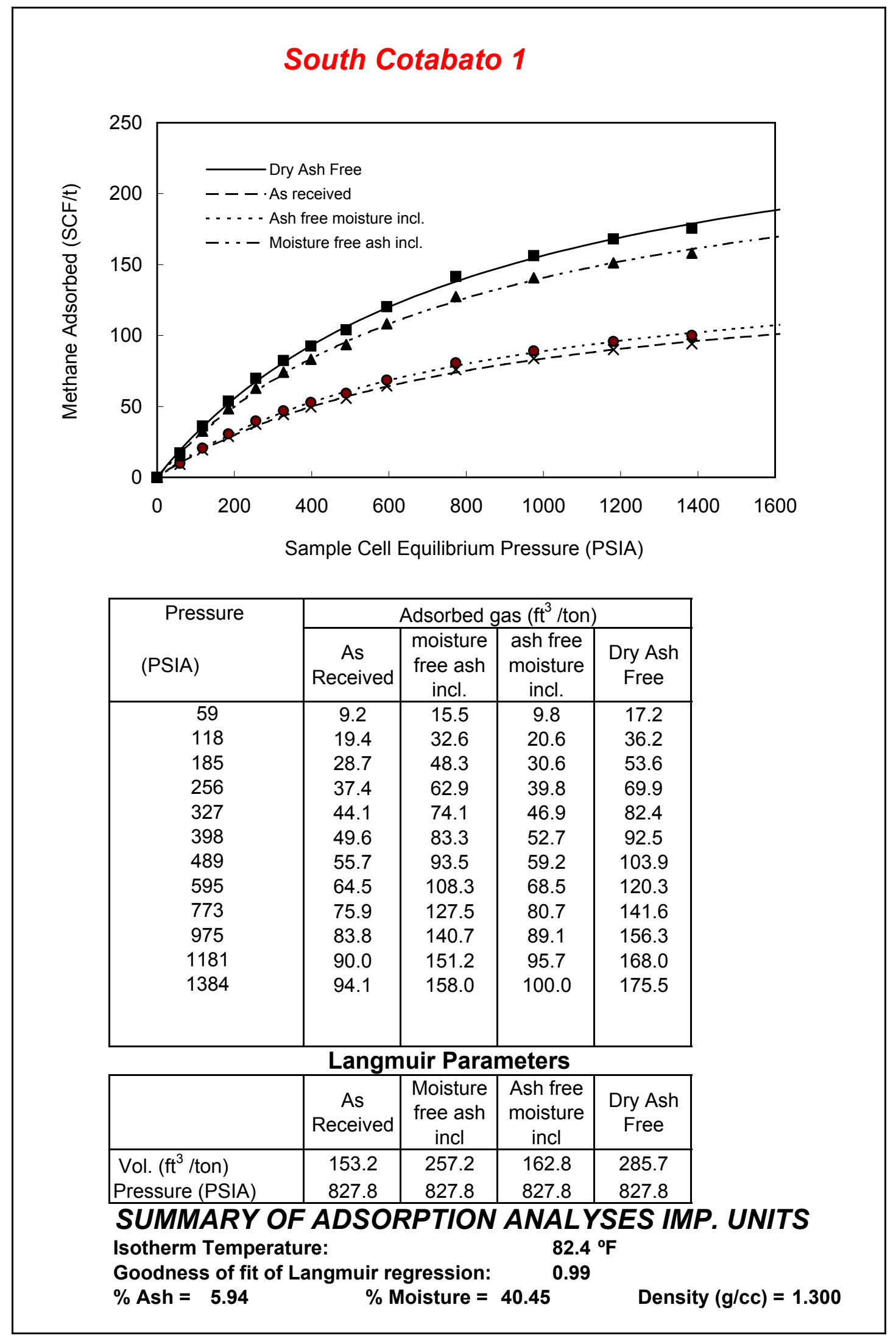




\section{Adsorption Langmuir Plot}

Cotabato

Sample South Cotabato 1

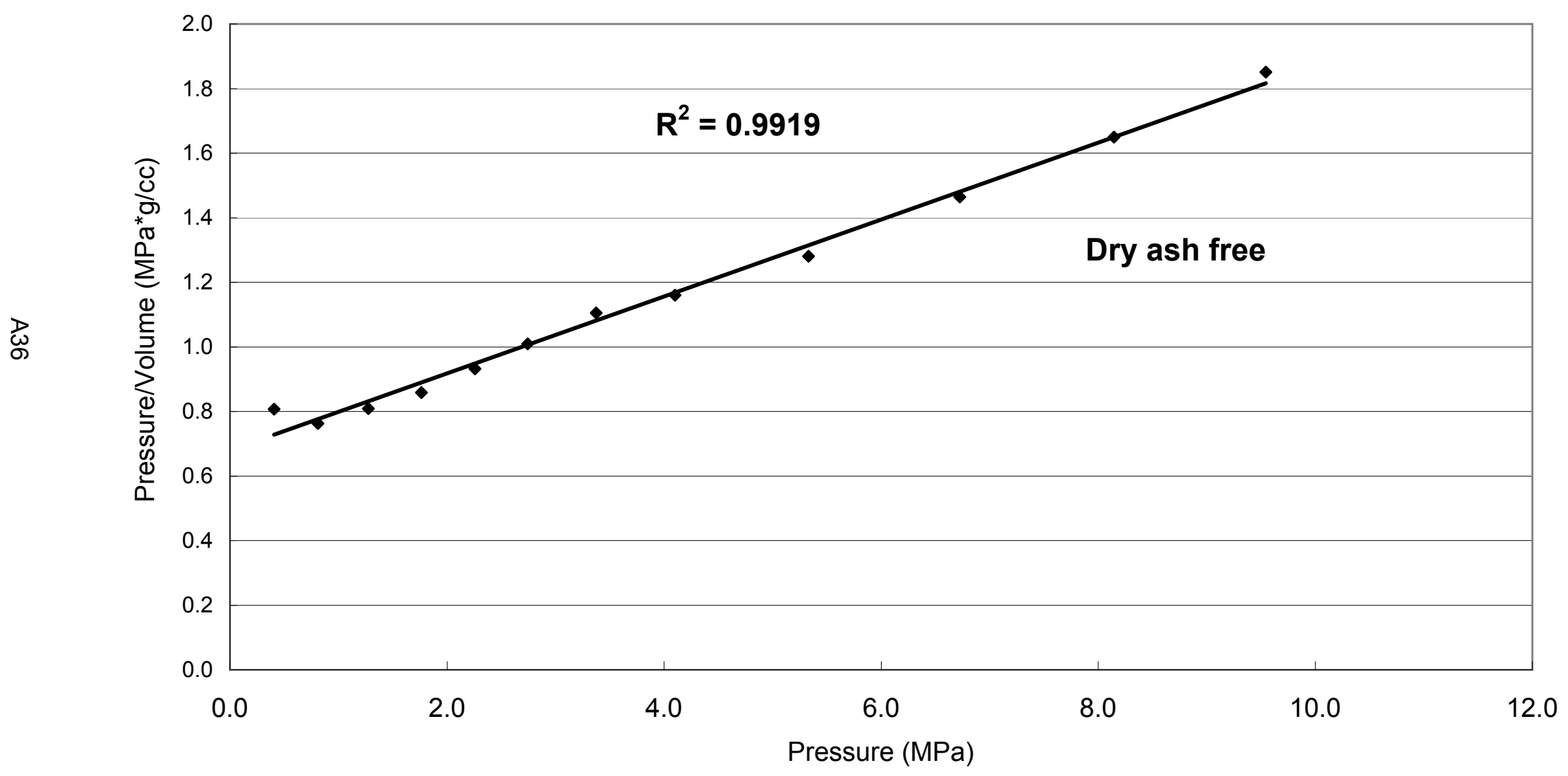




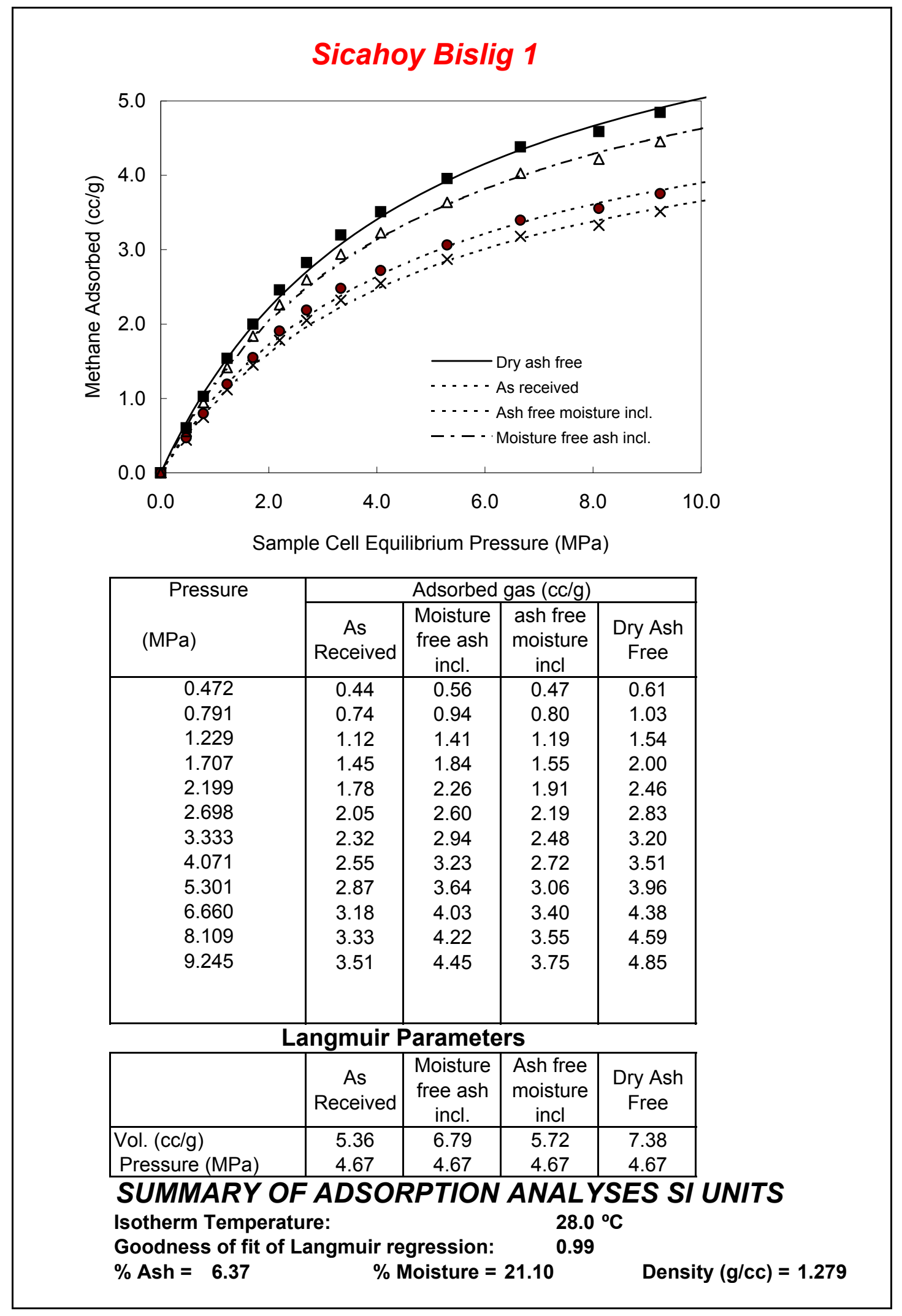




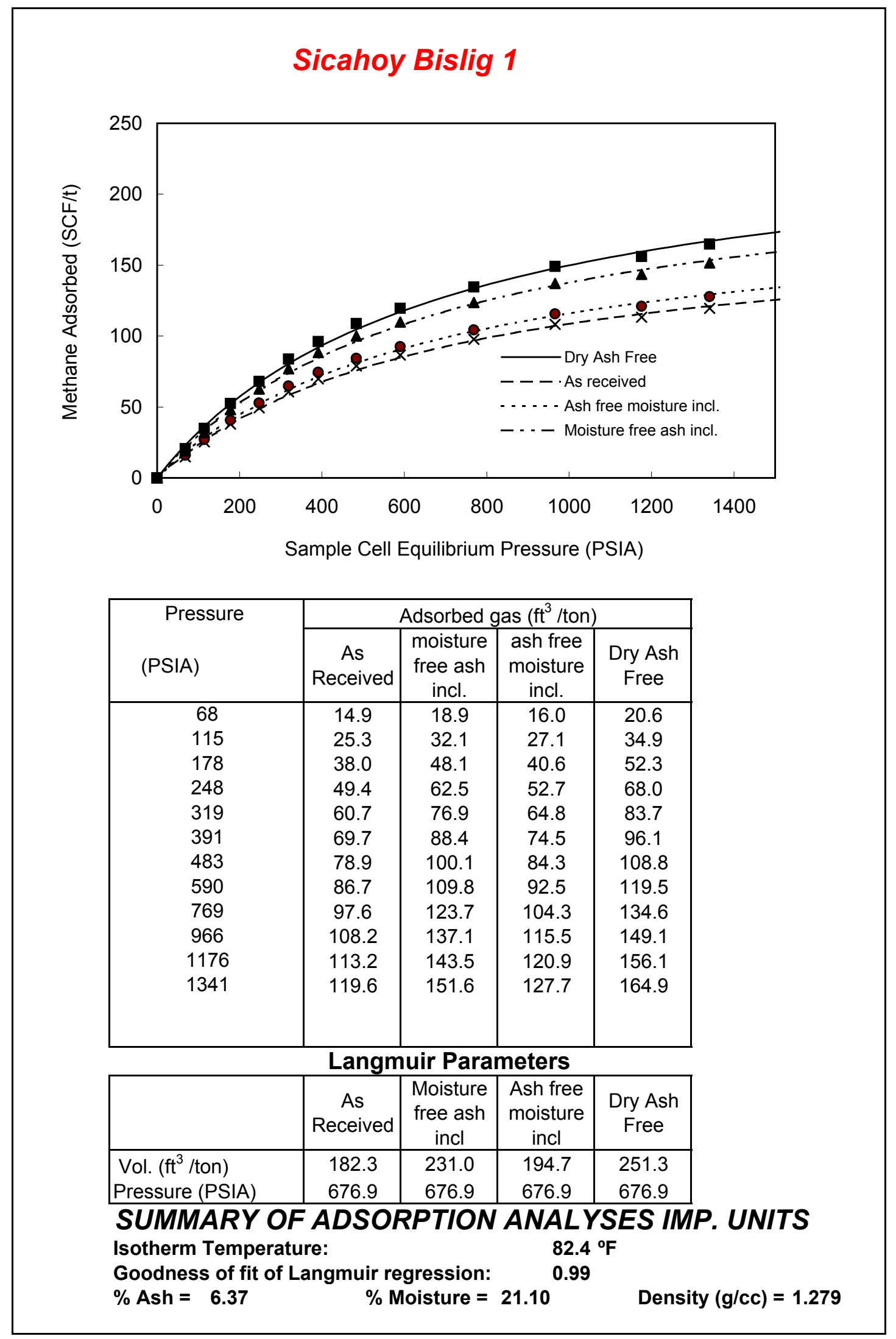




\section{Adsorption Langmuir Plot}

Surigo

Sample Sicahoy Bislig 1

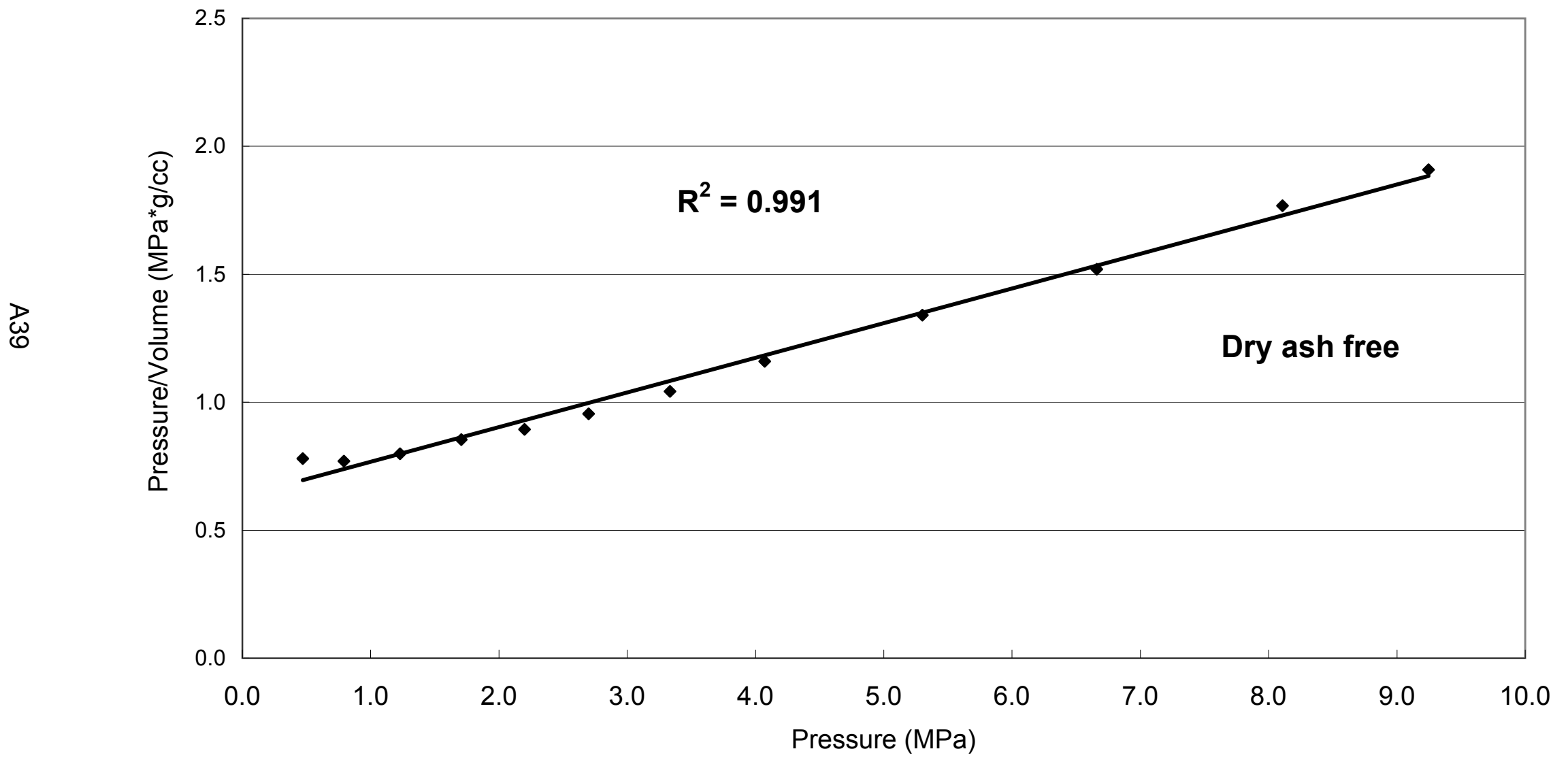




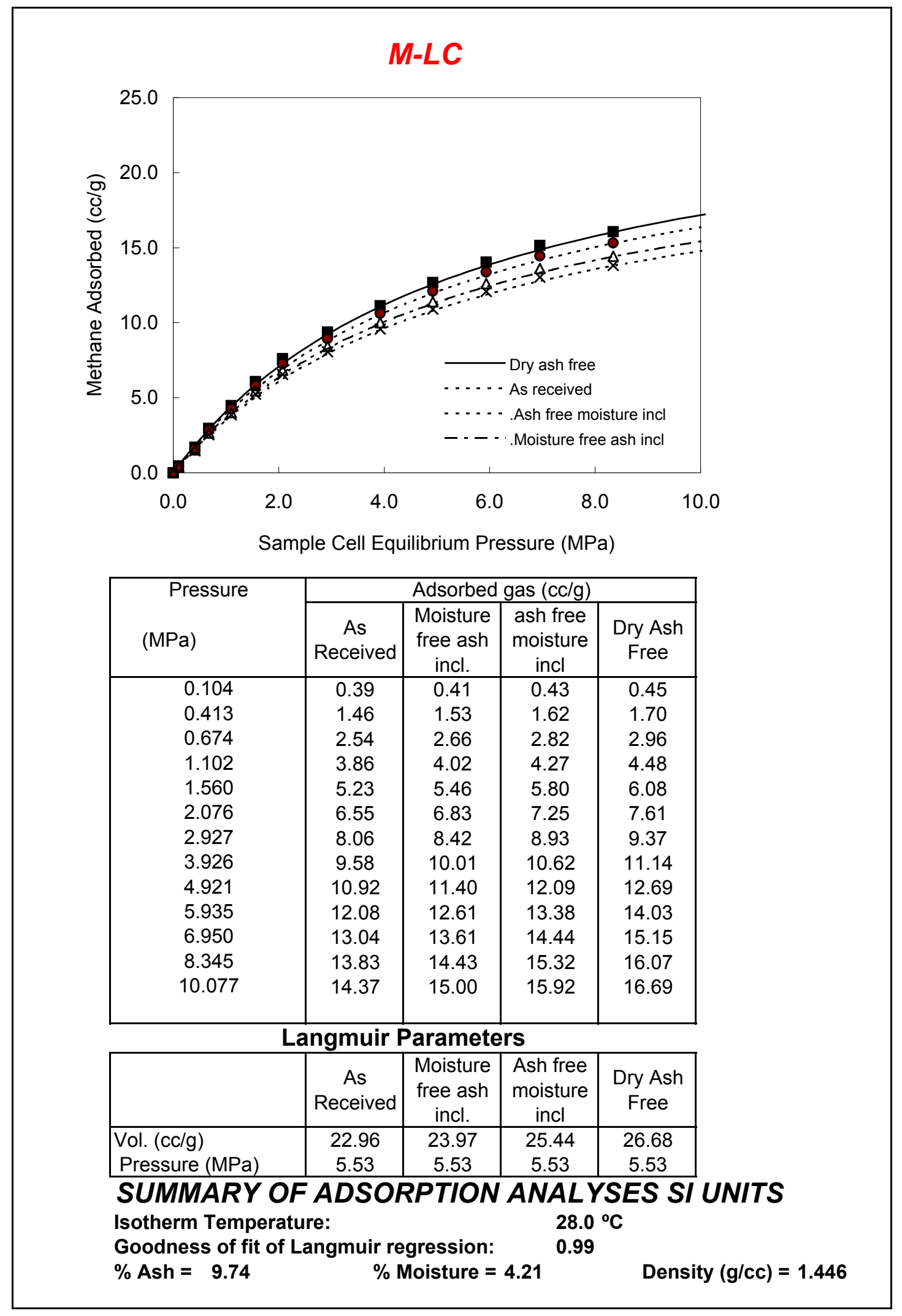




\section{$M-L C$}

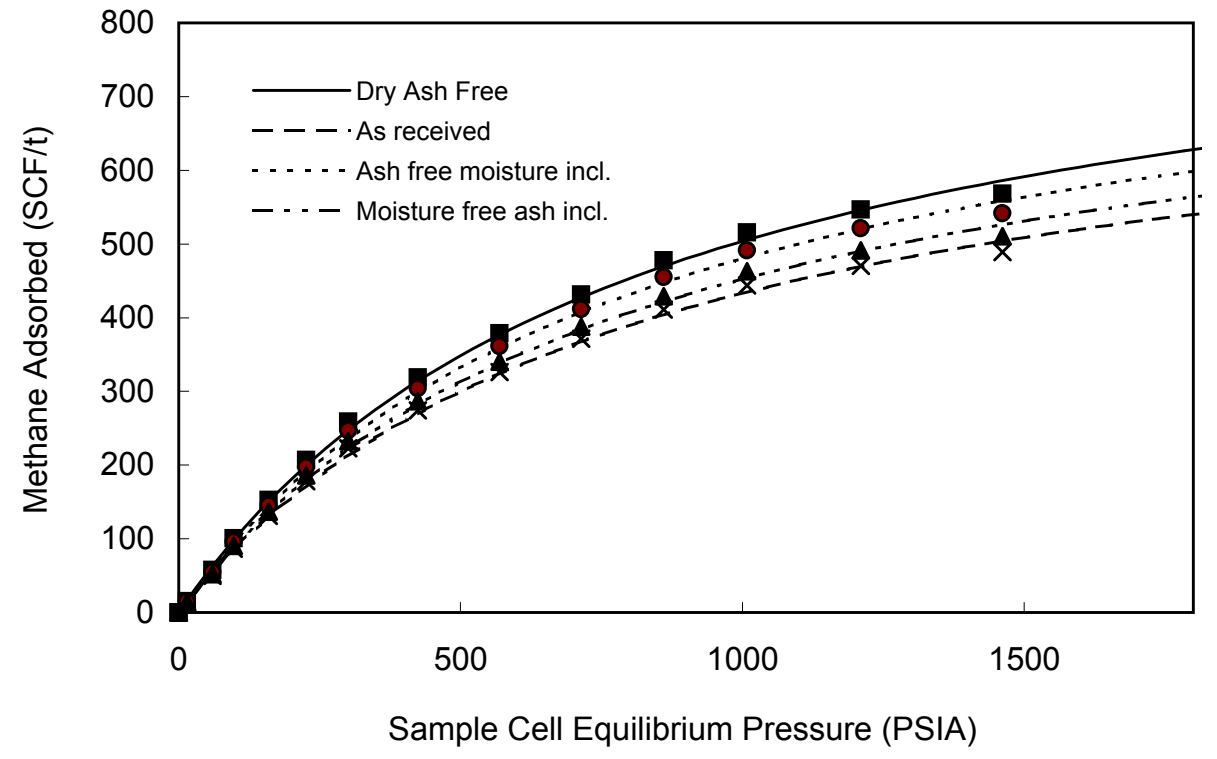

\begin{tabular}{|c|c|c|c|c|}
\hline \multirow{2}{*}{$\begin{array}{l}\text { Pressure } \\
\text { (PSIA) }\end{array}$} & \multicolumn{4}{|c|}{ Adsorbed gas ( $\mathrm{ft}^{3} /$ ton) } \\
\hline & $\begin{array}{c}\text { As } \\
\text { Received }\end{array}$ & $\begin{array}{c}\text { moisture } \\
\text { free ash } \\
\text { incl. }\end{array}$ & $\begin{array}{c}\text { ash free } \\
\text { moisture } \\
\text { incl. }\end{array}$ & $\begin{array}{c}\text { Dry Ash } \\
\text { Free }\end{array}$ \\
\hline 15 & 13.3 & 13.9 & 14.7 & 15.5 \\
\hline 60 & 49.7 & 51.9 & 55.1 & 57.8 \\
\hline 98 & 86.6 & 90.4 & 95.9 & 100.6 \\
\hline 160 & 131.2 & 136.9 & 145.3 & 152.4 \\
\hline 226 & 178.1 & 185.9 & 197.3 & 207.0 \\
\hline 301 & 222.8 & 232.6 & 246.8 & 258.9 \\
\hline 425 & 274.3 & 286.4 & 303.9 & 318.8 \\
\hline 569 & 326.1 & 340.5 & 361.3 & 379.0 \\
\hline 714 & 371.4 & 387.8 & 411.5 & 431.6 \\
\hline 861 & 410.9 & 429.0 & 455.3 & 477.5 \\
\hline 1008 & 443.6 & 463.1 & 491.5 & 515.5 \\
\hline 1210 & 470.5 & 491.1 & 521.2 & 546.7 \\
\hline 1462 & 488.8 & 510.3 & 541.6 & 568.0 \\
\hline \multicolumn{5}{|c|}{ Langmuir Parameters } \\
\hline & $\begin{array}{c}\text { As } \\
\text { Received }\end{array}$ & $\begin{array}{c}\text { Moisture } \\
\text { free ash } \\
\text { incl }\end{array}$ & $\begin{array}{c}\text { Ash free } \\
\text { moisture } \\
\text { incl }\end{array}$ & $\begin{array}{c}\text { Dry Ash } \\
\text { Free }\end{array}$ \\
\hline Vol. (ft ${ }^{3} /$ ton) & 781.2 & 815.5 & 865.5 & 907.8 \\
\hline Pressure (PSIA) & 802.3 & 802.3 & 802.3 & 802.3 \\
\hline
\end{tabular}

SUMMARY OF ADSORPTION ANALYSES IMP. UNITS Isotherm Temperature: $82.4^{\circ} \mathrm{F}$ Goodness of fit of Langmuir regression: $\quad 0.99$ 


\section{Adsorption Langmuir Plot \\ Zamboanga Sibuguey \\ Sample M-LC}

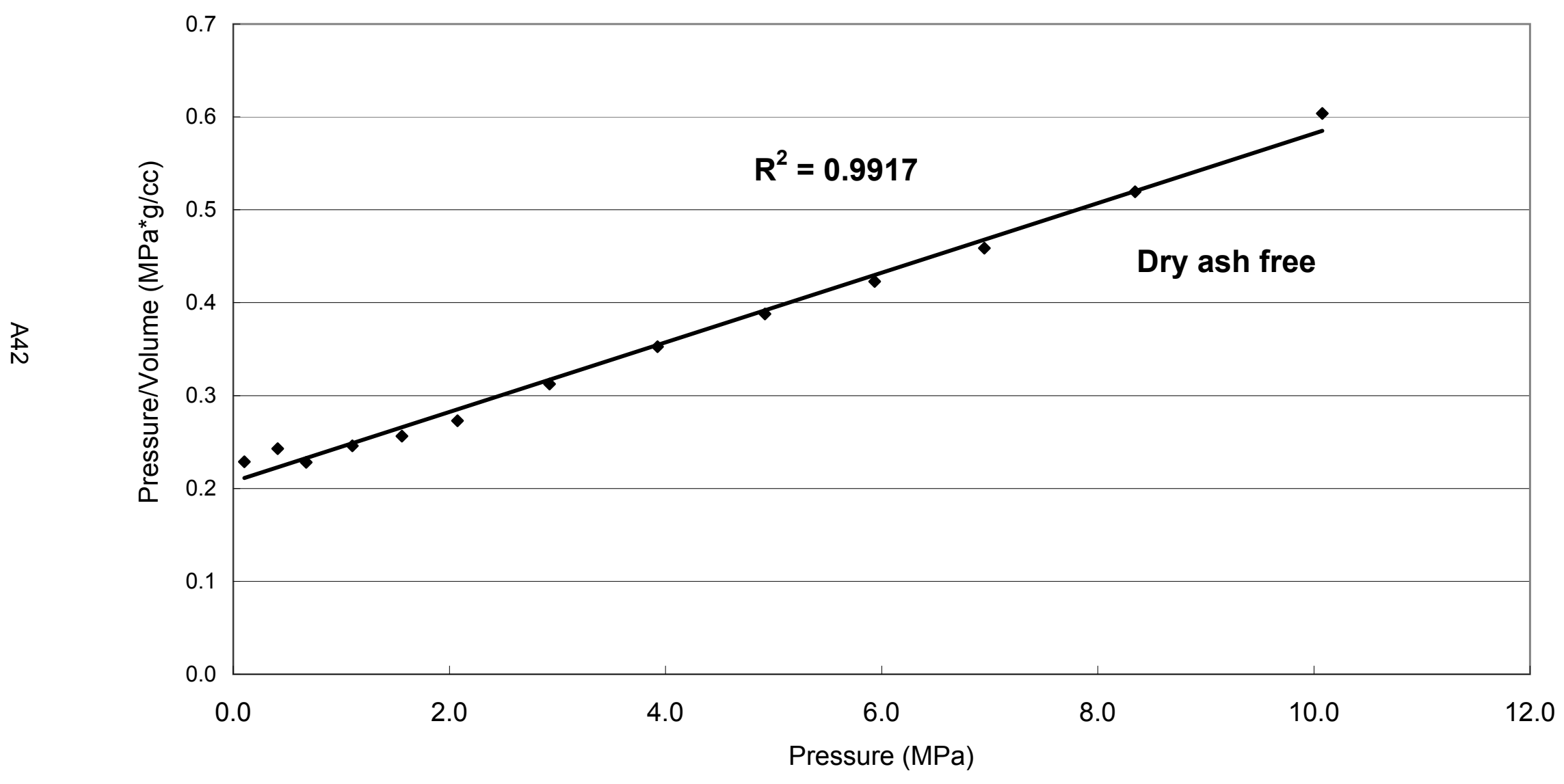




\section{$M-L A$}

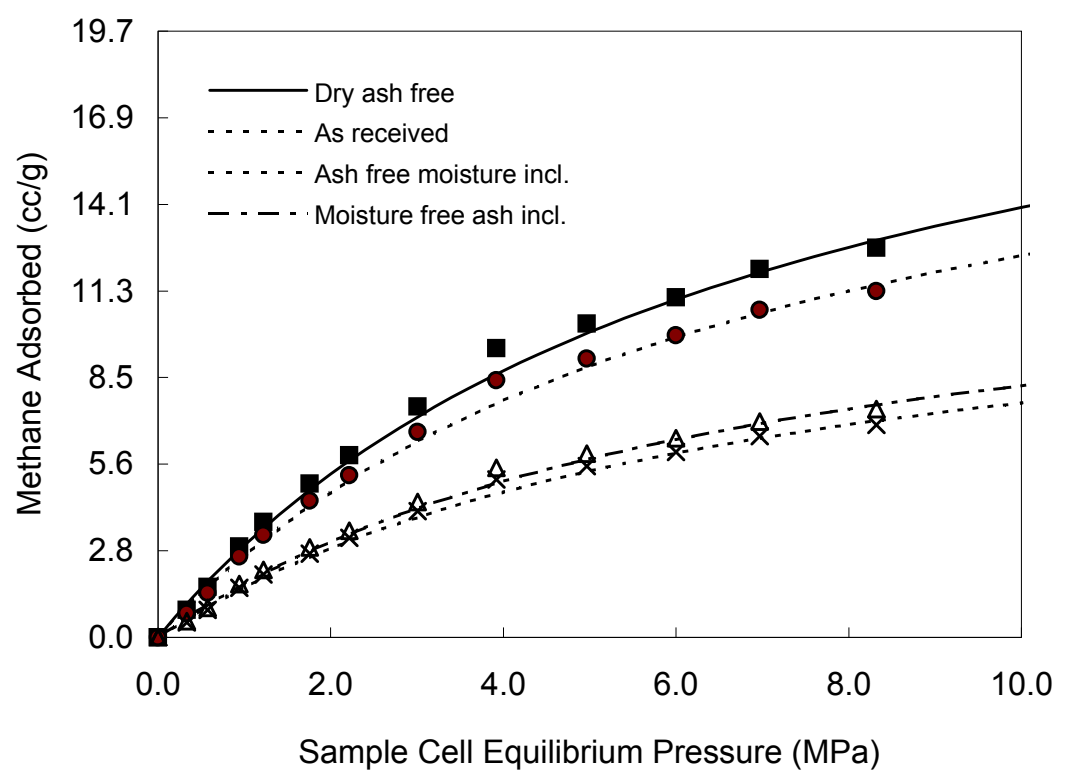

\begin{tabular}{|c|c|c|c|c|}
\hline \multirow{2}{*}{ Pressure } & \multicolumn{4}{|c|}{ Adsorbed gas (cc/g) } \\
\cline { 2 - 5 }$(\mathrm{MPa})$ & $\begin{array}{c}\text { As } \\
\text { Received }\end{array}$ & $\begin{array}{c}\text { Moisture } \\
\text { free ash } \\
\text { incl. }\end{array}$ & $\begin{array}{c}\text { ash free } \\
\text { moisture } \\
\text { incl }\end{array}$ & $\begin{array}{c}\text { Dry Ash } \\
\text { Free }\end{array}$ \\
\hline 0.332 & 0.49 & 0.52 & 0.79 & 0.89 \\
0.572 & 0.89 & 0.96 & 1.46 & 1.64 \\
0.942 & 1.61 & 1.73 & 2.63 & 2.96 \\
1.222 & 2.05 & 2.20 & 3.33 & 3.75 \\
1.756 & 2.73 & 2.93 & 4.45 & 5.01 \\
2.216 & 3.24 & 3.48 & 5.27 & 5.93 \\
3.006 & 4.10 & 4.41 & 6.68 & 7.52 \\
3.920 & 5.14 & 5.52 & 8.36 & 9.41 \\
4.964 & 5.57 & 5.98 & 9.07 & 10.21 \\
5.998 & 6.04 & 6.48 & 9.83 & 11.07 \\
6.970 & 6.55 & 7.03 & 10.66 & 11.99 \\
8.320 & 6.92 & 7.43 & 11.27 & 12.68 \\
10.060 & 7.36 & 7.90 & 11.98 & 13.48 \\
& & & \\
\hline
\end{tabular}

\begin{tabular}{|l|c|c|c|c|} 
& $\begin{array}{c}\text { As } \\
\text { Received }\end{array}$ & $\begin{array}{c}\text { Moisture } \\
\text { free ash } \\
\text { incl. }\end{array}$ & $\begin{array}{c}\text { Ash free } \\
\text { moisture } \\
\text { incl }\end{array}$ & $\begin{array}{c}\text { Dry Ash } \\
\text { Free }\end{array}$ \\
\hline Vol. (cc/g) & 12.90 & 13.85 & 21.00 & 23.64 \\
Pressure (MPa) & 6.89 & 6.89 & 6.89 & 6.89 \\
\hline
\end{tabular}

SUMMARY OF ADSORPTION ANALYSES SI UNITS Isotherm Temperature: Goodness of fit of Langmuir regression: $28.0^{\circ} \mathrm{C}$ $\%$ Ash $=38.58$ $\%$ Moisture $=6.85$

Density $(g / c c)=1.738$ 


\section{$M-L A$}

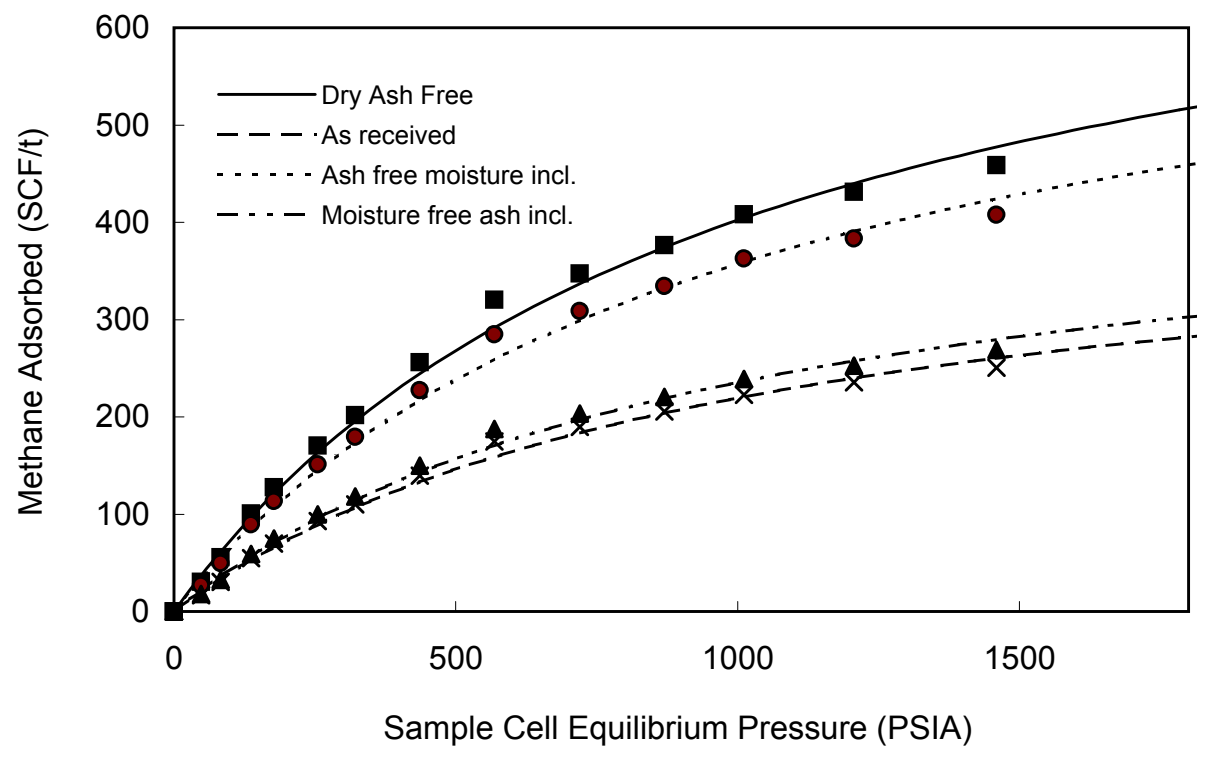

\begin{tabular}{|c|c|c|c|c|}
\hline \multirow{2}{*}{$\begin{array}{l}\text { Pressure } \\
\text { (PSIA) }\end{array}$} & \multicolumn{4}{|c|}{ Adsorbed gas ( $\mathrm{ft}^{3} /$ ton) } \\
\hline & $\begin{array}{c}\text { As } \\
\text { Received }\end{array}$ & $\begin{array}{c}\text { moisture } \\
\text { free ash } \\
\text { incl. }\end{array}$ & $\begin{array}{c}\text { ash free } \\
\text { moisture } \\
\text { incl. }\end{array}$ & $\begin{array}{c}\text { Dry Ash } \\
\text { Free }\end{array}$ \\
\hline 48 & 16.6 & 17.8 & 27.0 & 30.4 \\
\hline 83 & 30.4 & 32.7 & 49.6 & 55.8 \\
\hline 137 & 54.9 & 58.9 & 89.3 & 100.6 \\
\hline 177 & 69.7 & 74.8 & 113.5 & 127.7 \\
\hline 255 & 93.0 & 99.8 & 151.4 & 170.4 \\
\hline 321 & 110.2 & 118.3 & 179.3 & 201.8 \\
\hline 436 & 139.7 & 149.9 & 227.4 & 255.9 \\
\hline 569 & 174.8 & 187.7 & 284.6 & 320.3 \\
\hline 720 & 189.6 & 203.6 & 308.7 & 347.5 \\
\hline 870 & 205.5 & 220.6 & 334.6 & 376.5 \\
\hline 1011 & 222.7 & 239.1 & 362.6 & 408.1 \\
\hline 1207 & 235.5 & 252.8 & 383.4 & 431.5 \\
\hline 1459 & 250.4 & 268.8 & 407.7 & 458.8 \\
\hline \multicolumn{5}{|c|}{ Langmuir Parameters } \\
\hline & $\begin{array}{c}\text { As } \\
\text { Received }\end{array}$ & $\begin{array}{c}\text { Moisture } \\
\text { free ash } \\
\text { incl }\end{array}$ & $\begin{array}{c}\text { Ash free } \\
\text { moisture } \\
\text { incl }\end{array}$ & $\begin{array}{c}\text { Dry Ash } \\
\text { Free }\end{array}$ \\
\hline Vol. (ft ${ }^{3} /$ ton $)$ & 438.9 & 471.2 & 714.6 & 804.3 \\
\hline Pressure (PSIA) & 999.4 & 999.4 & 999.4 & 999.4 \\
\hline
\end{tabular}

SUMMARY OF ADSORPTION ANALYSES IMP. UNITS Isotherm Temperature: $82.4^{\circ} \mathrm{F}$ Goodness of fit of Langmuir regression: $\quad 0.96$ 


\section{Adsorption Langmuir Plot \\ Zamboanga Sibuguey \\ Sample M-LA}

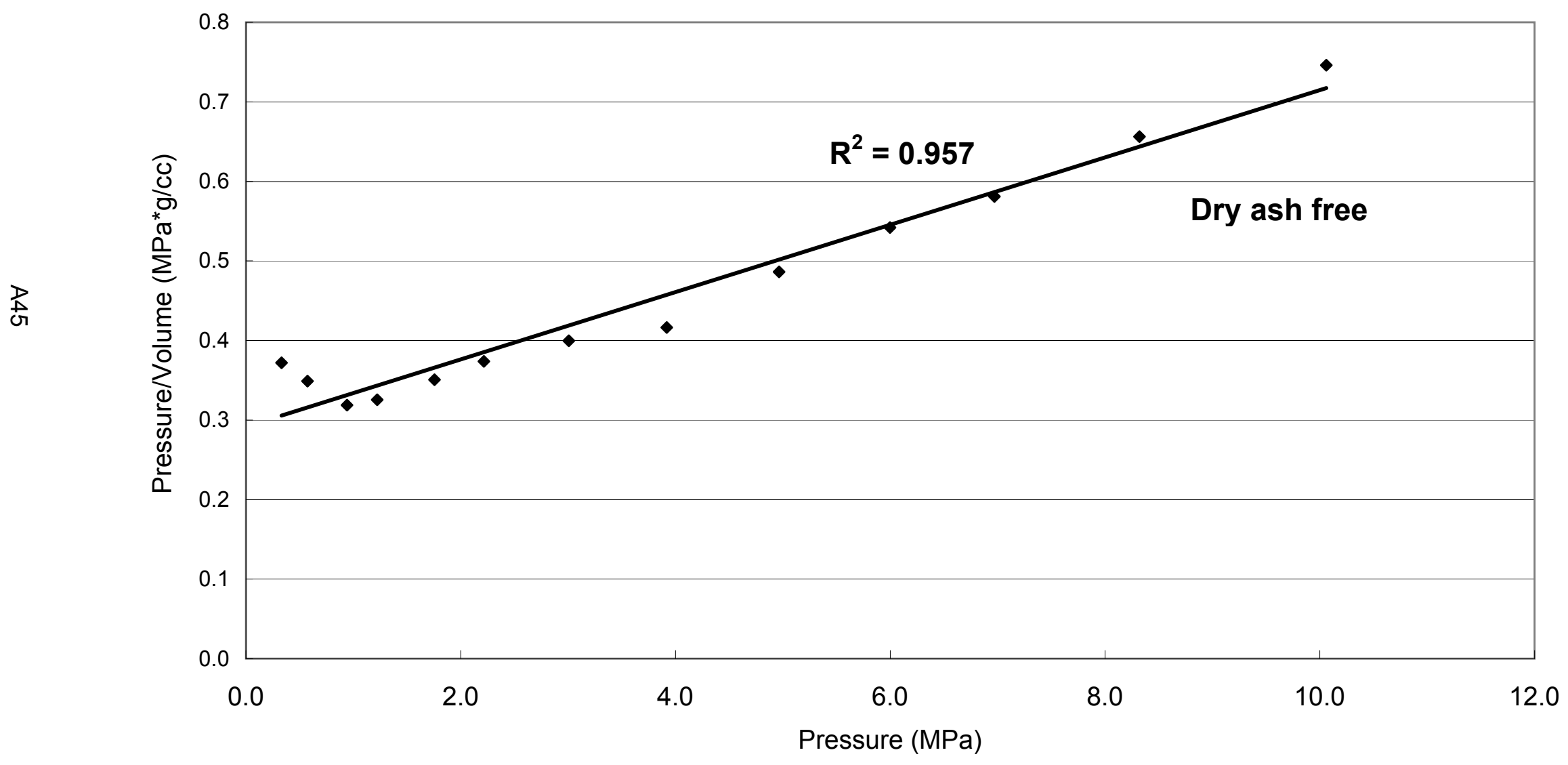




\section{Your Isotherms}

To help you interpret you data I have prepared a few short paragraphs to tell you how your data was obtained. If you have any questions please do not hesitate to contact us.

\section{Obtaining and interpreting isotherm data and Langmuir Isotherms}

Your high-pressure methane, carbon dioxide or mixed gas adsorption analyses were performed using a high-pressure volumetric adsorption technique. Your isotherms were measured on a custom made apparatus modeled after an apparatus designed and built at CSIRO Lucus Heights, Australia. The apparatus is based on Boyles Law. Simply, a known volume of gas within in a reference cell is used to dose a sample cell containing your sample. The amount of gas adsorbed, using the real gas law, in the sample cell is then determined based on change in pressure in the sample cell. Normally $100 \mathrm{~g}$ of sample is utilized in such analyses. Tests show that reproducible results can be obtained on samples as small as $25 \mathrm{~g}$ but the larger samples yield better quality data. Our instrument has four sample cells.

The pressures in the reference and four samples cells are measured using pressure transducers that are interfaced to a computer equipped with specialized boards and software for this purpose. The computer monitors the transducers and determines when equilibrium is reached as well as controls valves and switches for dosing and purging the references and sample cells. Following dosing of the sample cell with a known volume of gas, the pressure in the sample cell is monitored. As gas is adsorbed by the sample the pressure drops until equilibrium is reached; that is no more gas can be adsorbed by the samples at that particular specified pressure. Critical to obtaining quality isotherms is deciding when the equilibrium is reached. In our instrument we set a stringent test- equilibrium is reached only when the pressure in the cell does not change over a designated period of time. When equilibrium is reached the sample is dosed at the next highest pressure. We normally collect 12 separate pressure points selected such that the best Langmuir regression can be obtained. We can of course collect data at points selected by the client before hand. The temperature of the references and sample cells is maintained at the exact temperature requested by the client. The temperature is maintained within a tolerance less than $1 / 10$ of one degree centigrade.

For a routine adsorption analyses about five to six days are required once equilibrium moisture has been determined. 


\section{How we assure the quality of the isotherms- potential sources of error and recognition of problems}

With an apparatus such as ours the only potential error is a change in the characteristics of the pressure transducers, a leak in the system or non-isothermal conditions.

Our pressure transducers were selected for optimum performance within the range of pressures that isotherms are collected. They are not only factory guaranteed we crosscalibrate our transducers periodically to test for drift. The accuracy of our transducers is better than $0.001 \mathrm{MPa}$.

Prior to running your experiment the reference and sample cells and plumbing are pressure tested for leaks using helium. We do our leak tests at $9 \mathrm{MPa}$. Because the He molecule is smaller than either methane or carbon dioxide (the gases we normally do adsorption work with) using He assures us of a leak free system. If a leak were to develop during analyses (one never has) it would be readily apparent because the cells would never come to equilibrium at a given pressure (the leak would appear as an infinitely adsorbing material).

Non-isothermal conditions are not a potential problem utilizing our instrument unless a prolonged power failure occurs. Our bath temperature is maintained by a submerged electric heater and a circulating power. The heater is controlled by a temperature controller to a tolerance less than $1 / 10$ of a degree centigrade.

We periodically run a standard sample in our apparatus to confirm that all is well.

\section{Understanding Your Isotherms}

The classic theory used to describe the Type I isotherm for microporous materials with small external surface area is based on the Langmuir equation (1916). The Type I isotherm displays a steep increase in adsorption at low relative pressures due to enhanced adsorption caused by the overlapping adsorption potentials between walls of pores whose diameters are commensurate in size with the adsorbate molecule. The Type I isotherm then flattens out into a plateau region at higher relative pressure, which is believed to be due to the completion of a monolayer of adsorbed gas. The micropore volume is then thought to be filled by only a few molecular layers of adsorbate, and further uptake is limited by the dimensions of the micropores.

The Langmuir model assumes that a state of dynamic equilibrium is established between the adsorbate vapor and the adsorbent surface and that adsorption is restricted to a single monolayer (Gregg and Sing, 1982). The adsorbent surface is thought to be composed of a regular array of energetically homogeneous adsorption sites upon which an adsorbed monolayer is assumed to form. The rate of condensation 
is assumed to be equal to the rate of evaporation from the adsorbed monolayer at a given relative pressure and constant temperature. The Langmuir equation was developed with these assumptions and takes the following form:

$$
\frac{P}{V}=\frac{1}{B V_{m}}+\frac{P}{V_{m}}
$$

where $P$ is the equilibrium pressure, $V$ is the volume of gas adsorbed at equilibrium, $V_{m}$ is the volume of adsorbate occupying a monolayer, and $B$ is an empirical constant. A plot of P/V Vs relative pressure should yield a straight line whose slope will yield $V_{m}$ from which the surface area may be obtained. As shown on your figures a best fit Langmuir isotherm and the data points have been plotted for each sample.

The Langmuir Isotherm can be written:

$V(P)=\frac{V_{L} P}{P_{L}+P}$

$P=$ gas pressure

$\mathrm{V}(\mathrm{P})=$ predicated amount of gas adsorbed at $\mathrm{P}$

$V_{\mathrm{L}}=$ Langmuir volume parameter

$\mathrm{P}_{\mathrm{L}}=$ Langmuir pressure parameter

The difference between the measured amount of gas adsorbed $(\mathrm{V}(\mathrm{P}))$ and that predicted using the Langmuir Equation $(\mathrm{Vi}(\mathrm{P}))$ is a measure of error and is given as:

$\operatorname{Err}(P)=\operatorname{Vi}(P)-V(P)$

This error may be positive or negative. The square of the error is always positive and is a measure of the how well the calculated isotherm matches the data. This error can be calculate for each point and summed giving a measure of the overall error:

$S S E=\sum_{i=1}^{N} \operatorname{Er} \stackrel{2}{r}$

$\mathrm{N}=$ number of measured points.

We express the goodness of fit of the isotherm by calculation the correlation coefficient between the measured points and the calculate points. Our results generally yield correlation's that are better than $r^{2}=0.99$. and standard errors of Langmuir volumes of \pm $2 \%$. The errors for your samples can be found on the bottom of the data sheets that are included with each sample. 
In examining your data you should note that adsorption values are provided for the raw data and corrected for ash content. The ash content will also be corrected for equilibrium moisture content.

\section{References cited in appendix}

ICCP (International Committee for Coal and Organic Petrology), 1998, The new vitrinite classification (ICCP System, 1994), Fuel, vol. 77, p. 349-358.

Langmuir, I., 1916. The constitution and fundamental properties of solids and liquids. Journal of the American Chemical Society, 38: 2221-2295. 